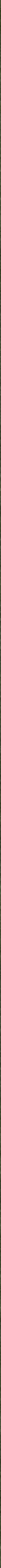



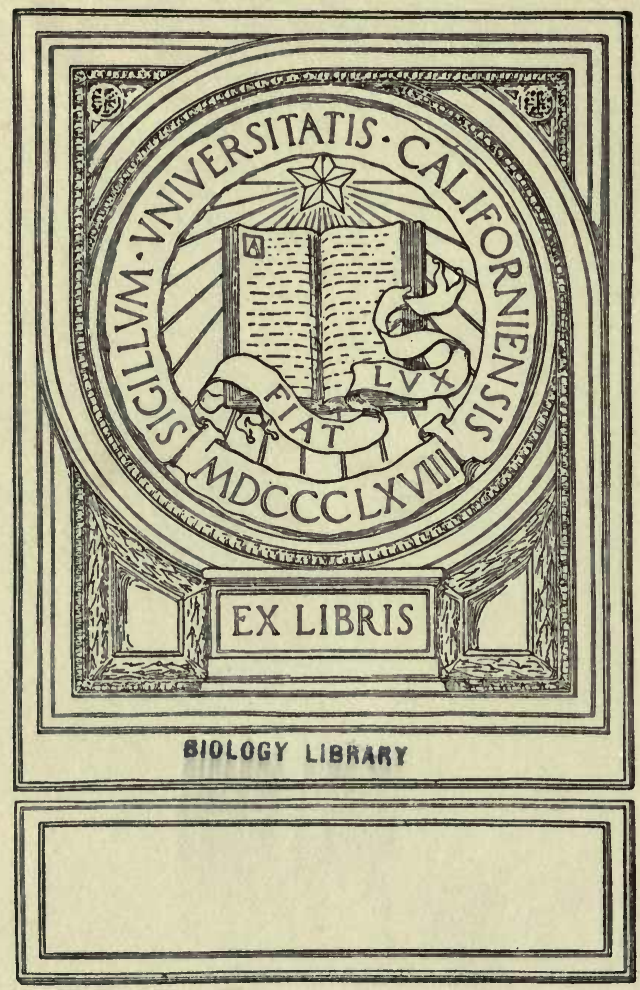
)

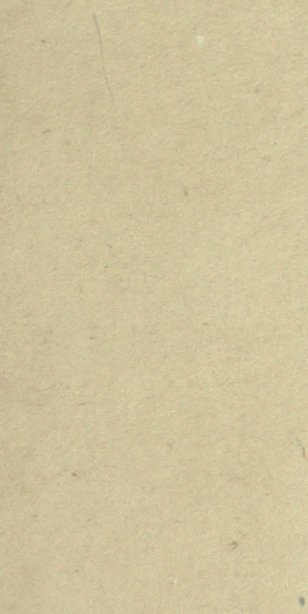


of 


\section{SOME BIRDS OF THE COUNTRYSIDE}

\section{THE ART OF NATURE}





\section{SOME BIRDS OF THE COUNTR YSIDE}

THE ART OF NATURE

BY

H. J. MASSINGHAM

E. P. DUTTON AND COMPANY 68I FIFTH AVENUE, NEW YORK 
QL690 G7M35 ENOLOG MDRMT' c

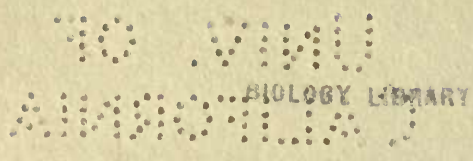

(All rights reserved)

PRLNTED IN GREAT BRITAIN 
TO - 
A portion of the material of this book has appeared in the "Contemporary Revierv," the "Nation," the "Nero Statesman," the "Spectator," the "Athenceum" and the "Daily Herald." I reish to thank their editors for the use of $i t$. 
"Hark! in what rings,

And hymning circulations the quick world

Awakes and sings

The rising winds,

And falling springs,

Birds, beasts, all things

Adore Him in their kinds ;

Thus all is hurled

In sacred hymns and order; the great chime And symphony of Nature."

Henry Vaughan, Silurist. 



\section{CONTENTS}

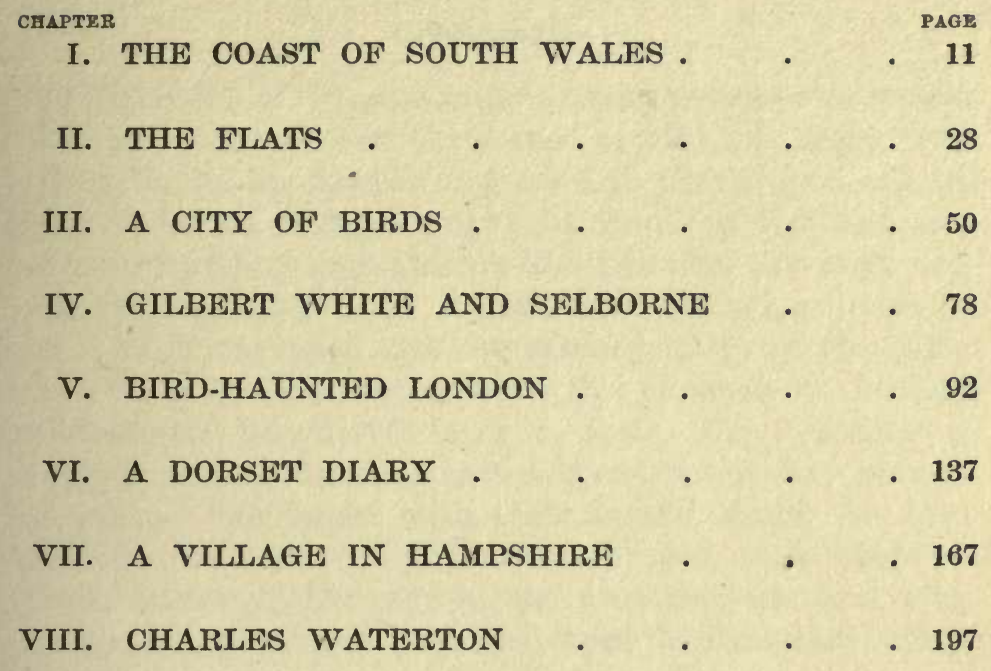





\section{BIRDS OF THE COUNTRYSIDE}

\section{CHAPTER I}

\section{THE COAST OF SOUTH WALES}

I

\section{Community}

7 HE coast of Pembrckeshire presses rocks and stones 1 and farm-houses into the service of tres: and hedges for its landscape, and one can climb upon one of the rock-cairns, natural cromlechs studding the land and patterned with orange lichens like ritualist carvings, and look over a valley void of tree, void of hedge, over an ambit of forty miles, and humanized only by the little white farm-houses dotted over the expanse as herring gulls scatter themselves over a field. The coastline is deeply indented, forming here a broad sandy bay horned by scarred headlands, with their snouts thrust far into the sea; here a grim little cove draped with bladderwrack, bronze in the rays of the westering sun and with perhaps a huge monolith uplifted from its arms and darkly sacrificial in appearance; here narrow fissures and caves tunnelling far into the land; here masses of plutonic rock like dismantled fortresses, and here friable composites so terrassed, frilled away and gnawed by the chisels and hammers and awls and rams of breakers, winds, rains, and frosts, that they look like the angular diagrams of citadels. Out at sea lie rocky islets whose irregular contours seem the petrified forms of scaled and warted amphibians, recumbent in the shallow Permian floods. For this is an ancient land, and for the shadowed brakes and leafy shelters of newer ages one goes to the lower rock-pools, where great bladed Laminarians, wavy sea- 
lettuce and delicate sea-grass wave their glaucous fronds in the watery twilight. Yet sombreness and desolation, even on the barest moorland, are only a passing impression, for, apart from the sunsets over the sea, populous with tints and shapes of every variety, the land on a fine autumn day is suffused with an opalescence into which the greens and browns of the earth are distilled, so that it has no more substance than the heavens.

But the birds were the country's refinement, expressing its primeval qualities not only by their wild cries and flights, but, paradoxical as it sounds, by their social life. In these solitudes they were largely undisturbed, but I was justified in looking further than this, and in seeing in these communities, not only of individuals, but of species, a condition of existence antedating their break-up by man. "Autumn is a signal for flocking, even among unsucial species, partly for migration (all our birds, except the town sparrows, migrate, whether for a thousand miles or a thousand yards), partly owing to the growing scarcity of food and the need of combining resources to secure it. But sociability is not confined to use, and in these rockbound wastes of sand, turf, bramble, gorse, ling and bracken, I was in a playground as well as a market-place, where I was a spectator from an unhappy world of a glee and lightheartedness articulated both in music and in disciplined mobility. Starlings, daws, and rooks always get on well together; here they had learned to sport as well as dine in company. ${ }^{1}$

When a lifting of the clouds had brought with it a lifting of the birds' spirits, the starling squadrons used to bear right through the flank of the stippled rook mass without breaking it or confusing their own order and wheel and plunge through the vanguard, emerging like light cavalry from the front of the advancing surge.

I once witnessed a beautiful manœuvre of these starlings.

1 Had a Martian naturalist visited this coast, he would have smiled indulgently if some countryman had told him that rooks are a tree-tribe and called black by the men of this earth. He would have been right about the colour, for in this country one sees rooks in their actual dress, not by our impression of it-living, iridescent, satin purple, glancing blue and bottle green. 
They were in the habit of using one of the rock tumuli upreared from the plain as a base for their wonderful corporate parade-flights, evolved out of centuries of social life, leaderless and psychically directed by " but a single thought." They flew off some way from the squat tower of rock, thinned their compact body into a long column, and made at it at full speed. The van of the column rounded the rock, appearing on the other (my) side of it, but, instead of the rest of the line following, the cable was broken, and the van, leaving the rocks, united with the rear, which had made one of those simultaneous right-about-turns habitual with starlings, and emerged on its side at the same time as the front ranks. One speaks in military terms of these intricate figures, but their rhythmical formality is never rigid, and they are really festival dances of the air, a leaping pulsation of life whose discipline is the condition of its freedom.

A collection of units is not of course a social order, but winter starlings are a corporate body with conventions and traditions of its own, while their active co-operation pro bono publico both coincides with and enlarges their capacity for happiness and for expressing what they feel in an artistic form of which they must surely be to some extent conscious. The sense of obligation to the social bond, instinctive in birds with a long social inheritance, reacts upon the flock by making each member of it more of an individual without being an individualist and encroaching upon the rights of his fellows. Each for himself in a flock or pack would make it extinct. Actual observation of animal societies makes it easy to understand how the more subtle and elaborate human societies are developed from them, and how a closer integration fosters rather than checks a wider differentiation.

It was strange to see magpies commingled with the rook, daw, and starling communities, an association I have never seen in any other part of the country-shouting with them, like them tumbling and careering in mistywinged flight about the rocks, like them perched in silence upon them. I noticed one evening that magpies were making for the same mass of rock ribboned by the starlings, and the sleeping chamber of the buzzards, singly, and in 
twos and threes, from all points of the compass. Finally, twenty-three had assembled, and with their long tails fanned, they began to gambol about the rock-face, chasing one another up and down and to and fro, oecasionally alighting on the summit, and then flinging themselves overboard with a gaiety and abandon of spirits that made me wish for a metamorphosis into their form. They looked like enormous, long-tailed, pied butterflies, flickering about a sunny wall (for the sun's level rays were caught upon the rocks), and when they were at rest (as happened rarely) like rows of guillemots on the ledges of sea-cliffs. Then the congregation gradually dispersed, the pleasure party was over, and in the gathering darkness the three buzzards, who lived in the neighbourhood, were circling on motionless pinions above the ancient crown of the rock pavilion. It would not, perhaps, be altogether fantastic to see in this rendezvousing for evening entertainments a tradition of the magpie tribe, broken elsewhere, but preserved in its continuity in a place where the larger birds are still permitted to exist, for even curlew put aside their wildness here, and stalked the field next to my cottage like turkeys, curlew which elsewhere are, to us, but the disembodied voices of mystery and remoteness. ${ }^{1}$

The magpies remind me of the pied wagtails, which are a duodecimo edition of them in colouring, and volatile, inconsequent nature. A flock of over forty used to roost in the tall bracken thirty feet away from the house, and here, too, there was ceremony. They took about three-quarters of an hour every evening to settle down; first sibilating and prancing round in the air in their helter-skelter manner, like leaves whirled by contrary gusts, swooping and dipping about, until, one by one, they came down upon the tips of the bracken. Then up they rose, flew about like mad, and darted down upon

1 Many more weeks of observation that I was able to afford would be necessary to discover whether these parties were a regular feature of magpie life in this district. But I am sure it could not have been a chance gathering, for the birds lived in pairs and small family parties over the country, each pair or group, so far as $I$ could see, living in a more or less definite area. 
the roof, pranking about on it in their clean winter livery, and then up again, and, after another waltz round, down upon the bracken, perched on the thick vegetation like minute fairy clowns. Then up again, blown upon by the slightest puff of caprice, their little feather heads summoning them for yet another burst of unstable energy. But there was more in them than I thought, for one night, they were performing in the usual way, when the fierce little blue hawk, the merlin, swooped like a javelin upon them, and with loud chirri chirris they rose in a body, not, as I expected, in a panic, but a fury, and disappeared from my astonished gaze at the heels of the merlin, who took himself off as quickly as he came. They were soon back again, wagging their tails in insolent triumph behind them. ${ }^{1}$

Meadow and rock pipits (which are not a rare bird, as commonly assumed) are also being constantly caught in several minds as to where they shall go, rushing about for minutes at a time before they make them up in a flight which, owing to the short intervals between the closing of the wings, is not one of curves like that of chaffinches and wagtails, but acute angles, so that, in flocks, they look like the diagrams of constellations in the first page of The Times atlas. But, disorderly as their movements are, they are driven by the exhilaration of social contact, and seem, like those constellations, to obey a complex planetary force of attractions and repulsions whose mighty music we hear in the poets.

In this stern land linnets abounded, tenderest of the race of birds, and $I$ would often stumble into the magic circle of a linnet choir. Bounding through the air, they would turn some wind-corner at right angles, and come pelting down among the gorse in which I stood, and burst into iridescent peals of fairy music, as though the burning bushes were translating into song the secret of their beauty and their fragrance. Or, in the evening, when the spectral tide of mist was curtaining the ground, I

${ }^{1}$ Surely a remarkable illustration of the protective and survival value of social life among animals. The merlin frequently comes to the coast from the "interior" in the autumn to prey upon small waders, pipits, wheatears, etc. 
would hear that concert of sweet sounds penetrating it, though the singers were invisible to me, and the very atmosphere was as laden with melody as the grass blades with drops of water.

The waders, except the large whimbrel and curlew, only used the bays as inns, refreshing themselves for a few hours and continuing their journey (some of them from the Arctic) southward. However small the party, the different species mixed, and where in the morning the tawny sands stretched out in solitude, there in the afternoon were ringed plover, dunlin, and little stint to gladden them, darting to and fro after the amphipods, like shrimp in a pool, while in comical imperturbability and ungainly dignity, to make a contrast with these shoresprites, trailing tails along the sand, and holding heads high in air, shambled to the water's edge the shags in their dark, metallic greens, grotesque, clockwork toys, Neanderthal birds. ${ }^{1}$

The tame curlew (the tame curlew! it is like speaking of a shirtless waiter.) enhanced the impression of the companionableness of life in these solitudes. Free from persecution, they used to disport themselves in the air above my head, their long incurved bills very conspicuous against the background of flawless sky, which threw into relief the delicate reddish grey of the plumage. Among the rocks, clustered with naticas, acorn-barnacles and limpets, the plumage is a duller monotone of sandy brown. They are not always sure-footed when climbing among the long streamers of bladder-wrack draped from the rocks, nor prudent at table. I once saw a curlew drag out a large crab from a crevice, despatch it with blows from the bill, and then nearly choke himself with it, dancing about on his shanks and shaking his fine head. A pair of whimbrel usually associated with them on the shore, easily distinguishable from curlew at twenty-five yards range (at which distance $I$ would sit in plain view and watch them) by smaller size and bill, darker crown

1 The shag, though more local than the cormorant, takes its place in Pembrokeshire. In diving for fish, the bird (like the cormorant) leaps right out of the water, turns a semi-circle, and then goes in head first. 
and a whiteish eye-stripe running above the eye and circling the crown like a diadem, as in the woodlark. The whimbrel character, too, is different, more sedate and bolder. They stalked magnificently about the rocks and ran out into the trough of a receding wave after a little flat-fish and then hard back again to escape the next roller. The whimbrel breeds nowhere in these islands except in the Orkneys and Shetlands, I believe, and my pair stayed only a few days before the tidal impulse of migration caught them once more and swept them southward. When they took flight with the curlew, their strident cries were queerly out of harmony with the whistle of the curlew, most musical, most melancholy. ${ }^{1}$

The artistry of bird life gains not by economy but multiplying, and its sociability is thus a delight to us as it is to them.

Two illustrations of this intensifying beauty of multiplication occur to me which may just be worth relating. I was watching the nuptial offices of herring gulls on a broad spit of sand outside Poole Harbour. I have noticed that this gull, after pairing with his mate, will sometimes stand erect (without the aid of the glass he looks as though he were on tiptoe) upon her back, quite motionless, except for movements of the tail, with fully extended wings and shouting at the top of his voice. It is as though he called bright sun, sparkling waters, golden sand and scented air to witness his services in the perpetuation of life. By a strange coincidence it chanced that half a dozen of the birds were posed in this manner at the same time and all loudly declaiming their epithalamia. Visualizing the scene over again, I can only see its comedy. But though one gull, thus advertising his share in the contributions of the species to the future birthrate, is of psychological rather than of æsthetic interest, the six of them rejoicing in unison became something entirely different-partakers in a ceremonial, a thanksgiving rite which seemed to reveal the dim origins of the manifold religious forms of savage tribes in sacrificing or making offerings to or dancing before their gods in gratitude or appeal for fertility. The action of the birds became

1 A local name of the whimbrel (from the cry) is the titterel. 
formal and conventionalized into a kind of artistic rhythm.

For the second illustration, I was visiting a gullery on the coast of the Isle of Wight. Hundreds of birds were flying overhead and wailing together in a tangle of wild cries, intercrossing in beautiful curves and patterns between two skies, and rounding the air for minutes at a time without moving their angular, thin-bladed wings. Others were seated on their nests among the samphiremere untidy wisps of hay-while others stood out upon the points and bluffs of the chalk cliffs, festooned with ribands and patches of bright green grass, the rocks scattered among them burnished with the pale gold of algæ. It was the colour of the manes of Blake's lions. The intimate harmony of white cliff, white bird, blue sea and sky, green grass and golden algæ, was such that the animate gave personality and expression, gave the grace, freedom and intensity of the living to the inanimate. It was the gull mass rather than the gulls which breathed life into the dead cliffs. "Beauty and sublimity in nature," wrote Professor Pringle-Pattison, " are not subjective imaginings; they give us a deeper truth than ordinary vision, just as the more developed eye or ear carries us further into Nature's refinements and beauties." But to appreciate the ulterior value of landscape we must have life in it and to deepen our appreciation, multitudinous life, and it is then that the animism of past ages becomes a reality to us. As Lord Kelvin said so justly: "A tree contains more mystery of creative power than the sun from which all its mechanical energy is borrowed. An earth without life, a sun and countless stars contain less wonder than that grain of mignonette." How much less wonder than a bird of the air! In its beginning the earth gave life to her creatures; they were born of her dust, and in return they give life to her.

In the sandy bay (a quarter of a mile in length and, at low tide, a hundred yards in depth) and on the headlands in sight I once reckoned thirteen hundred gulls, greater and lesser blackbacks, blackheads, and common and herring gulls, and as the beauty of this physical world is sometimes unearthly when the spirit behind its substance seems to 
break through into visibility, so the rays of the sun balanced on the horizon's rim, throwing golden shafts over the sea, and pouring into the blacks and pearls and whites of this gull multitude, was the handiwork of a supreme artist "whose smile kindles the universe." The seaward sky was lit up with a salmon pink effulgence, hazed with gold and arched over waters of the lightest sea-green, the crests of the wavelets breaking on the shore reflecting the ultramarine of the landward sky, while the wet sand reflected the pink light, turning to a delicate purple under the shadow of the black headlands, and the waters of the pools the lustre of the sun's disc. Within this vast theatre of interchanging colours, the sun's rays, broken into fragments like stained glass on the surface of the sea, and radiant as the prismatic feathers of a humming bird, tinged the white breasts of the gulls into a roseate blush of a loveliness that was hardly of this world. It was the further world of Prometheus Unbound, and these gulls might well have been the Spirits of the Hours, declaring with the heavens the glory of the Lord.

\section{II}

\section{The Individual}

A solitary heron frequented one of the little rocky bays, and the sight of his thin form, angular as the shadows of the rocks, brought me a contrasting impression-that of the wildness and apartness of the land on which I moved, a stranger. I shall, therefore, continue this chapter with an account of two birds less social than the others, and expressing as few others do to the same extent, the spirit of places untrammelled by human labour, abiding through all human change and withdrawn from human influence-the stonechat and the buzzard.

The stonechat is a gaily painted little bird; and does not shun the bright eye of day. His clothing is indeed almost as rich as the siskin's or yellow-hammer's-head and throat a velvety black bordered by a white collar, back also black and marginated with chestnut, deep brown wings with a white patch conspicuous in flight, 
rump white, and breast a vivid rufous paling to rusty red in the autumn. The females and young are duller. Stonechat and wheatear are birds of the waste, but each lives in its own kingdom, the wheatear on sheepwalks, downs and stony uplands, the stonechat in thick scrub and on gorse and bramble-clumped commons. On this coast the two kinds of country were often only separated by a frontier turf wall, and though both species perched upon the wall as common ground, they never trespassed, unlike the internationalist linnet and meadow pipit.

The stonechat was so common in the land that, except for the pipits and linnets, it outnumbered all the other small birds, its double pebble-clapping call-notes-hroitjack, hwit-jack-jack-spurting into the air in every direction I walked. Though not a social bird, it is his custom to travel about in small family parties from the tips of furze or bramble and over the highest fronds of the bracken. Distinctive in habit and colouring as they are, they wave their tails on their perches vertically like wheatears, spring into the air and hover, a variegated ball of colour in the sunlight, like pipits, plunge after flying insects like fly-catchers, and flicker their wings on alighting like hedge-sparrows. But these tricks of manner are not plagiarisms or gobbets, being blended into the whole musical phase of the stonechat's individuality. They are motionless for about ten seconds to the minute on their exposed perches, silhouetted like toy birds at the extreme point of their bush or plant. A favourite perching place was the top of foxglove stems with the wide, slaty sea for a background. It was intriguing to see these little Italian Comedy birds standing erect against the huge, uniform canvas of the grey and furious sea-poetic, but with a touch of the fantastic. Then down among the long grasses or up in the air and back upon their lighthouses, throwing out invisible rays of what speculation we know not over the wilderness.

In action, the stonechat is agile and sprightly, and association is no doubt responsible for the legend that he takes none too rosy a view of life. But there is no call to be so anthropomorphic about him or libel the 
immortal gladness of nature. All we can say, as we watch him restlessly flit from one plant head to another, a minute Ahasuerus of the waste, is that unconsciously he seems to gather into his pretty body something of the brooding solitariness of his environment.

A more profitable reflection comes from observing the character and quality of the song. Like many other birds, the stonechat resumes singing after the moult, even in hard weather. The song is inaudible at any distance, and incapable of being sustained for more than a few notes. But though less varied and exuberant than the wheatear's, it is one of the sweetest in minor bird music-sweeter than the whinchat's, which is harder-a silvery, low and desultory warble. There is a perceptible resemblance in it to the shrilling notes of the robin, but it does not glow like his, and is much more subdued in tone. Now, it is noticeable that the small birds which inhabit rough and stern desert places, smitten by the wind, have a peculiar delicacy and fragility of songvoices of porcelain. Linnet, wheatear, rock and meadow pipit, goldfinch, whinchat-their singing is of a pearly lustre, quite different from the diamond brilliance of the louder and coarser notes of the wood-birds. Among the larger birds, the contrast is achieved more on the plane of colour and form-the luminous whiteness of herring gulls, the roseate breasts of one species of tern, the delicate pencillings of the plumage of curlew, whimbrel and the smaller wading birds, the masterpieces of line in their elegant shapes. It is the same with the flowers, the eyebright and thyme on the sheepwalk, the thrift among the rocks. And the contrasts appear in different terms, one intertwining with another-the slenderness of the harebell accentuating its own and its neighbour's value, the fiery stain of the ragwort relieving and intensifying the uncouth and colourless waste, each by its distinct and opposite quality. So the warble of the stonechat, uttered in spring when hovering in the air, and in more meditative autumn from a perch, is an æsthetic device of the most fertile of artists to mingle and relieve her beauties, and is to the rough furze-clad common what the coral bill of the chough is to his black body, and the 
crimson flowers of the red-rattle to the drabness of the marsh.

But if contrast is one method, expression, the expliciting of the implicit, to use a clumsy phrase, is another, and this brings me to the buzzard, whose life and movement translate into a more active music the character of his home.

The buzzard-Butco vulgaris as he is called with unconscious irony - has taken a better hold on life since the war, and somewhat broadened his distribution, not because gamekeepers are any more intelligent or merciful than they were (many of them still regard nightjars as a kind of hawk, and string them up on a branch as feathered felons), but because of the relaxation of gamepreserving. If it can hardly be expected for some years to come that gamekeepers or collectors will acquire an elementary knowledge of science or regard for other people, still the fact that the buzzard's food is practically the same as the kestrel's-blindworms, adders, lizards, mice, rats, moles, frogs, earthworms, crane flies, grasshoppers, Coleoptera, etc. - should penetrate the skull of the game-preserver and allow this very handsome species a corner in the sun.

The buzzard is coloured mottled brown with silvery flecks and buffish variations, and is easily distinguishable from other hawks by large size (except for the Iceland Falcon, it is the biggest of the Falconida), a leisureliness of disposition, and, when the bird is soaring, by the roundness of the wings, which are curved upwards at the terminal feathers and show the sky between the primary quills, as do the raven's. In districts where they are left at peace, they are more social than most of their fellow falcons ; they migrate in company, and in the autumn travel in small family parties.

It was thus that I saw them every day for nearly three weeks, for their residence was only a hundred yards from mine, that same conical, granite pile isolated on the moorland, where the starlings held their air-sports. Being from East Anglia, where they shoot everything that moves, I was amazed at the tameness of these great birds, and that they did not salute the sovereignty of 
the human form divine by getting out of its way as quickly as they could. But the absence of game-preserves and the kindlier sentiments of the neighbouring farmers were not the only reasons for the approachableness of these buzzards. Without his being exactly lazy or inert in temper, the metabolism of the bird leans to the passive, and he is lacking in the initiative and dashing, mettlesome spirit of the peregrine and the merlin. In fact, I should call him rather a meek bird. $\mathrm{He}$ is very conservative and never in a hurry, remaining for hours at a time on the same perch in the calm of lethargy, frequenting it regularly and sticking to his own neighbourhood. But the most remarkable thing about the buzzard, as indeed about the kite, is a kind of dualism of appearance. On the ground and in the lower ether he is quite without distinction or nobility, dragging his body through the air with heavy flaps of the wings and looking as dowdy and sullen when perched on some eminence of rock with all the drapery of moor, cliff and sea about him-a hunchback Richard III on the throne in his state roomas upon the turf walls and the tops of the cornstooks. In the trailing flight close to the ground there is no grace, poise nor rhythm: it is simply getting from one place to another.

But what a transformation when the bird has shaken off the almost stupefying influence of the earth, and, like a ship leaving the sluggish estuary of some river and quivering to a responsive life in the wind and tide of the open sea, climbs to a more buoyant atmosphere! Between stalking and flying the heron rises from a Daily Telegraph prose to the epic, but the difference between the buzzard's upper and lower flights is still more sharply accentuated. The peregrine's flight (and I have seen it at its best) is notable for speed, power, balance and command ; but the buzzard's style is less dominating. The bird gives itself to the air in majestic surrender, and the languors of its earth-bound course are translated into a solemnity of motion and stateliness of carriage which seem to dignify the whole landscape. It (birds are not neuters, but to say he or she-who is two inches larger than the male-is an awkwardness) ascends the 
sky in great spiral curves, sweeping outwards from the loop in long crescentic lines and exposing the under surface of the wings and body when the circles are made, and the delicate silver marginations of the brown feathers when the back is slanted towards you.

It appears a very slow flight, but the continuity of rounded design in the ascent makes the speed deceptive, and in a minute or two the bird is a speck in the sky. As the bird climbs the sky, its pinions are expanded quite motionless, and the piloting, both in a strong wind and a light breeze, though preferably the former, appears to be done by the swinging of the body and deflecting of the fanned tail, whose twelve transverse bars are conspicuous at not too far a distance. When the grand fellow is some way up there is no flapping of the wings, which serve it in immobility better than our legs do us, running over the solid earth. Until the bird outranges the detailed visibility of a field glass, it is quite easy to test this, the primary quills overlapping and shutting out the sky when the wings are moved. As Darwin says, in The Voyage of the Beagle, when he was watching condors soaring over Lima:

"I intently watched the outlines of the separate and terminal feathers of the wings : if there had been the least vibratory movement these would have blended together, but they were seen distinct against the blue sky."

The same applies to our buzzard.

If one lies on one's back and watches these great birds, who have learned the secret of travelling the air without a stir, tracing out their smooth patterns upon the vault of heaven directly above one, they exercise an emotional appeal which is a medicine for us living in these gloomy and turbulent days. They seem to impress not only a consolation and peace upon the mind, but a confidence in the stability and eternal fitness of the universe, a sense of its breadth and grandeur and permanence beyond all transient phenomena, and to open the spiritual ear to the "onward advancing melody," as Lotze called it, of the whole of creation. Our western world may crack and even be shattered, but the cosmos still goes on. 
Yet birds of this splendour of motion, seeming as they rise higher and higher to be emblems of lofty thought and proud imagination, are known among men as "vermin." I have no doubt at all that these gyrations were for pure enjoyment (which in nature is almost invariably expressed in what is to us as artistic form), and that they had nothing to do with business.

When the three of them were floating the ether in company, they used to toy with one another, dashing down and swerving off just before colliding, and then soaring upwards to renew the sport. In this recreation they cut all manner of intricate designs in the air, in a beautiful combination of strength and lightness. They were frequently pursued and bullied by other birds, particularly crows and rooks, and you would see one of them flying off with a black horde at his heels, like a potentate attended by pages. But I failed to see any animosity or fear in these attacks : it was Elisha and the urchins. But if the buzzard cursed, he did not smite his persecutors. I once saw a meddlesome rook begin harrying and hustling with a fine, showy, St. Georgeand-the-Dragon air, dashing down like a thrown spear at the back of the buzzard and stopping dead six feet above it, to sail away and play a discreet David once again. Then I received a token of the solidarity of the rook tribe, for three other rooks turned up from nowhere, and the tactics of the original aggressor at once changed. He plunged down upon the poor buzzard with so impetuous a rush, turning at the last moment to flick him with his wing, that he completely upset the buzzard's balance, who turned a complete somersault and dropped about thirty feet. A pair of crows (most uxorious of birds), too, used to drive down upon the buzzards with depressed wings or hang above them with their legs dangling, and feinting and standing, or rather flying, on guard with a vastly impressive parade of martial prowess. The buzzards only glided aside to avoid the swoops, and I never saw these Christian birds make the smallest attempt at retaliation or self-defence. Either the black air-Arabs got tired of the sport or the victim of their horseplay was driven off the field. I 
saw a raven treated in the same way and with the same results. It was only on these uncomfortable occasions that I heard the " mewing" of the buzzards-wheewur, wheerour-a complaining, drawled, high-pitched and melancholy cry.

One thing I found they did which $I$ have not seen recorded in any of the scanty accounts of the bird I have seen $;^{1}$ they hover almost as brilliantly as the kestrel does. One watches them floating downwind in their tranquil way and then curling round into it. There is a perceptible stiffening of the whole body, the wings are slightly elevated above the body's level and the primaries tilted up and round. There they remained upwind, with scarce a flicker of the wings visible to the naked eye, and as though suspended by invisible wires. Then, after a short or a long period, the tension was relaxed, and the birds went downwind again to hover in a different place, or, with the wings half-open, dropped like a stone to the ground. Buzzards fly, but they do not hover for fun, and this characteristic which I observed every day is evidence in itself that their food is similar to the kestrel's.

But the most striking feature of the life of the buzzard is its intimate relationship with the landscape, for in mid-air they seem to articulate the moors, the sea, the bluffs and promontories, to enlarge and ennoble the whole prospect, a kind of nucleus to a wide magnificence of outline. When they are out of the sky it appears to reach down lower and to enclose one more narrowly, while land and sea seem dwarfed and emptied, as though a fine headpiece to the page of an old book had been rubbed away. There was a headland forming the horn to a bay close to where I was living, and running a long way out to sea. All of it but the point was a broad-backed, barren moor with cromlechs and hut circles upon it, looking like the vertical plates on the

1 Mr. Arthur Brook's The Buzzard at Home (Witherby, 3s. 6d. net) is the most recent and the best $I$ know. It is a vivid and intimate account (gathered at considerable personal risk on a precipitous cliff) of the buzzard's domestic life, and contains a number of remarkable photographs. 


\section{THE COAST OF SOUTH WALES}

hide of some huge Jurassic Stegosaur, the rock mass at the extremity being the heavily armoured snout and skull of the monster. Wheatears, jackdaws and buzzards were its only inhabitants, but the delicacy of the first and the jauntiness of the second, dashing low and parallel with the ground full speed at the stone walls bounding the edges of the cliffs, and shooting perpendicularly upwards like arrows with their depressed wings for the barbs when the wind caught them full face, were a relief and a contrast to its stern and sombre wildness. But the buzzards, wheeling on calm wings above it, expressed it to perfection and gave its ageless bulk a life and meaning it lacked without them. And they handed on the tradition of an older life that has passed away, for even as I gazed upon them, so did the Neolithic men who have left their ancient memorials on the moor. 


\section{CHAPTER II \\ THE FLATS}

I

THE north and north-east coast of Norfolk is like 1 a padded shoulder thrust out into the sea to beguile many a wind-worn, feathered navigator, blown out of its course, to strike sail and rest upon it. Norfolk, Cockaigne of the collector, glory of gunners, is my native place, but to pay a filial visit was not the reason which took me to the mud flats and saltings of the coast between Cromer and Hunstanton in the autumn, for the dwellers therein are a rude people and inhospitable alike to bird and traveller.

The flats themselves cover an immense district, and though partly marsh and partly mud, and varied with broad sandy expanses, low turf walls running seawards, sandhills tufted with coarse marram-grass, saltings carpeted with the fleshy, glaucous foliage of sea-aster, samphire, sea-lavender, and sea-purslane, rushy pools and narrow streams, present a uniform stretch indescribable both in feature and beauty. On the plain there is nothing between you and the horizon; earth and sky seem interchangeable, and so boundless is the adventure of the mind that you might as well be walking upon the one as the other. The business of this water-wedded land is other than to rear a multiformity of shapes and contours for eyes to climb and wind among; it becomes what the white sheet is to the film camera, a surface for colours to come tumbling out of the paint-box and run and play and wheel upon like schoolboys out of class. Come unto these yellow sands and there take hands.

I remember one evening on the flats, washed in a clear, mirage-like transparency-nothing on land, sea or sky was thick or muddy-so that the effect was that of a 
wideawake dream, an other-worldliness without a hint of vagueness, strange yet real. Algæ were pinkish-red and grass lit by golden brown; the pools were a deep cobalt, and in the distance were strips of pale purple, blue, and softest roseate, while over all the sky was streaked, ravelled, and combed with white on a blue ground. When the sun set, the seaweed on the slime glittered a metallic emerald, the pools glowed an intense violet, and the sun itself a molten gold.

Chromatic dramas of this kind were always performing -there were several houses a day-but one in particular was impressed upon me. I was on the shore at Holkham, two miles from Wells-next-the-Sea. Just beyond the sandhills there is a long and thin crescentic line of pines, in front of which "the lone and level sands stretch far away." If the traveller stands in the middle of this smooth floor on a fine day he will seem to be surveying the landscape of a different planet, so singular is the effect of the great semi-circular disc of buff and yellow sand, broidered on one side by the ultramarine of the sea, intense as the blue on the Virgin's robe in an old Italian picture, and on the other by the darkest green of the pines. The effect was not only singular, but estranging, shrinking the human personality beneath even the sandhoppers, an alien in an unpeopled and inhospitable wilderness.

The population of these flats is chiefly gulls and wading birds. On first acquaintance with the latter one feels no more desire to discriminate between them than to count the separate leaves of a tree. It is by no means easy, for they are greatly persecuted, most of them of an exceeding shyness and of a strong family likeness, nor is there any cover by which to approach them. In colour, too, they are much alike, especially after the moult, and to identify, to particularize these grey, fawn and silvery forms, drifting, gliding and whirling over the waste in the pearly light bathing all the land, like shadows in a dream, seems somewhat to sacrifice the general, harmonious impression, to drag them out of an environment into which they so perfectly melt. Indeed, the wide desolation of the flats seems to endow 
these waders with a new power of living among them, as other birds do in the air, so that they belong to another dimension, which is aerial and yet of the earth. They seem not so much to run over the ground as to fly with closed wings, as if struck and propelled by wandering breezes. Thus, concrete objects become shifting and liquid and inseparable, and to their wavering the wonderfully subtle and evanescent colouring of the flats contributes-appearing as they do on a fine day opalescent, from which one might pick out pinkishgreys running into blues, making roseate mauves, again running into browns, and again into emerald and turquoise. This soft interblending matches the flights of the birds crossing and circling one another's tracks, while through all are heard their plaintive, wild, and musical cries, so fine and remote as to seem themselves part of colour and light.

This would have been all very well for an artist, but your naturalist who cannot put a name to what he sees is like the artist who cannot put a meaning to it. Ringed plover, the charming little brown bird with a black gorget on his white breast, was the most numerous species, outnumbering the too sparse flocks of dunlin (called "stints" here by the gunners), and soon identified by the broad splash of black over the lower breast. Curlew, too, were thinly distributed, and I saw but few pigmy curlew (called clumsily in the books "curlew sandpiper "), the duodecimo edition, so to speak, of the curlew. I once had the good fortune to see a party of fifty or sixty redshank dipping over the flats, but greenshank-a very shapely bird, readily distinguishable from redshank, not so much by the muddy olive of the legs hardly to be picked out from the mud, but by their three inches larger size, deeper and rounder call, conspicuous white rump, and more sedate and dignified ways-were much rarer.

Sometimes, if one peers over the top of a turf bank, one may see a small flock of grey plover feeding on the mud. In build they recall the shape of their larger cousins, the stone-curlew, or "thick-knee," being compact, sturdy, and somewhat thickset. By the autumn, 
the black of the underparts has become white, and the dark mottled browns of the upper an ashy grey, so that the birds have turned ghostly to meet the season of mists. They are-pity for them-remarkably tame, and are reluctant to take their graceful, easy flight, very different from the impetuous dashes of redshank and sanderling, quickly alighting again. Altogether their disposition is calmer and more leisurely than that of other shore birds, and they stride over the mud with a certain sedateness quite unlike the fanciful, irregular runs, so characteristic of the smaller waders. They have a delightful habit of pointing as they feed, the body being slightly tilted forward and the neck thrust out on a level with the back, and there they stand in an attitude of fixed attention, as though musing on the fate of the doomed crustacean before they gobble him up.

The most abundant of the smaller birds, next to the ringed plover, were sanderling, "easily recognizable," say the books, "easily recognizable" by the absence of the hind-toe. If, however, a professional ornithologist can mark the absence of a pedal appendage an inch long from the foot of a bird smaller than a song-thrush a long way off, on a grey expanse of mud flat, I cannot, and preferred to distinguish my sanderling by the blackish mottlings of the back (pearl-grey in winter), the light stippled reddish-brown (lost in winter) of the upper breast, and the luminous white of the underparts. Small bands of knots (a circumpolar species), Cnut's table bird according to Michael Drayton, and distinguishable by a strong rufous blush over the throat and breast (also lost in winter), and a rather stockish build, roamed the flats, and turnstones (Norvice, "tanglepicker," and very blurred in colouring after the moult), were in more or less the same numbers. They are mining specialists in the small crustaceans lying under stones, and they will (it is said) often co-operate to heave them over with their bills. ${ }^{1}$ Mr. Boraston's Birds by I.and and Sea wonders how it is that the other Limicolae who see the turnstones trotting industriously to and fro on

1 See a delightful account of co-operation among turnstones in vol. v (pp. 52-55) of Morris's British Birds. 
orange legs in conspicuously pied and tortoiseshell livery, investigating the seaweed and turning the pebbles over, do not go and do likewise. The reason, perhaps, is that the flats so swarm with minute amphipod and molluse life that there is no serious competition or need to take the bread out of the turnstone's mouth. Last of all comes the little stint, a demure elf of a bird no bigger than a chaffinch, who seemed to me more like a miniature sanderling than dunlin, as he is commonly called. Very self-possessed was he (there were only a few) in his six-inch body, cloaked in ashy-brown, with the miles of lone, level, immemorial wastes around him. I saw no golden plover, nor oyster-catchers, supposed to frequent the coast in large numbers.

At first it seemed to me that these different species of shore bird, though on the best of terms, did not mix to any great extent. But this was a false impression, and a marked characteristic of the waders is their gentle sociability. Sanderling and ringed plover were constantly together, and twice I saw little stint among them. Curlew fed both with greenshank and redshank, and turnstones associated with dunlin and sanderling. Nor was it altogether foolish to feel pleasure at my correction, since the uniformity of habit, residence, shape, colour, language, and character makes the birds a single community, and any tendency to exclusiveness would have marred the fitness of things. Birds were the first animals to develop sympathy, and here it was pictured in the art of nature as well as represented in character.

But this by no means implies the capitalist's nightmare of Socialism, and I came to see that differentiations in character were none the less present for being subtle and hard to unravel. Apart from the marked personalities of curlew, dunlin, and turnstone, for instance, the ringed plover draws away quite definitely, if not too far, from the other members of the wading family to introduce an alien presence. The differences of physical type (shorter bill and dumpier body) are but the externals. Not only is he the least shy of the group, and his wistful toolee, toolee, one of the most expressive and frequent cries, but his actions on the ground are not the same 
as those of sanderling, dunlin, and stint. He has a way of making a swift dash along the flat, and then standing stock still, with head and neck hunched in on his shoulders. Then he will begin to peck away at the sandhoppers, making another little run and stop again to reflect. Meanwhile, the sanderling, moving on an evener and less thoughtful disposition, is dibbling away here and there and everywhere, stopping not for spiritual food, but some choicer morsel which has caught his roving eye. Even from these trivial indications we can guess that the little plover is a shade more independent and original in temper, a shade more likely to contain within his loins the destinies of a mightier race in the future.

But I saw something much more interesting than this charming habit of a species, namely a highly developed variant of a single individual of it. On the further side from me of the creek dividing the mud flats at Blakeney was a party of twenty-three of the little plovers; on the hither two birds alone, one a ringed plover, the other (it was, I think, a young bird) showing the white and warm buff and slightly decurved bill of the pigmy curlew. The pair moved about the mud feeding, and when they got at all separated one of them would run up to the other, and they would stand for a time motionless and close together. Then the plover (called sandlark here) ceased feeding and stood meditating, while the little curlew went on with his meal. When the latter had moved some distance, the plover took his elegant little run and resumed his cogitations close to -as my thick wits at last discovered-his comrade. All of a sudden the plovers on the other side of the creek took flight, but little curlew and little plover remained behind, quite unconcerned and happy in one another's company. It was a rare experience to be admitted into the secret of this intimacy, as it was disquieting to reflect that any day it may be ruptured, and one or both of these avian friends disappear into the bag of the gunner. Mr. Hudson, I remember, relates a similar comradeship between a blackbird and a pheasant, Romanes between a widgeon and a peacock, and Montagu in the Supplement to his Dictionary between a pointer and a Chinese goose. 
The fact is that if we believe in animal love we must also believe in animal friendship. If, on the other hand, "love" is simply a hyperbole for the reproductive instinct, then friendship is one for the herd instinct. The former theory, however, is now scientifically untenable. "It is hardly necessary," write the authors of the Evolution of Sex,

"to argue seriously in support of the thesis that love-in the sense of sexual sympathy, psychical as well as physical-exists among animals in many degrees of evolution. . . The fact to be insisted upon is this, that the vague sexual attraction of the lowest organisms has been evolved into a definite reproductive impulse, into a desire often predominating over even that of self-preservation; that this again, enhanced by more and more subtle psychical additions, passes by a gentle gradient into the love of the highest animals and of the average human individual."

The evolution of love, said Henry Drummond, is pure science. Sexual love, also, survives the nuptial season in some species, and Mr. Julian Huxley has established the remarkable fact that it precedes it as well. Great crested grebes engage in a lengthy period of courtship before sexual intercourse, which is coeval with nestbuilding, takes place.

But love, removed from its purely sexual context, is allied to friendship. If, again, sexual differentiation is as old as the first organisms, the social relation is not much younger, for the former began with the Infusorian Volvox, the latter one stage higher, when one-celled animals began colony-making. The one has had almost as much time to evolve into friendship as the other into love. Therefore I feel that Mr. Hudson is on sound scientific lines when he writes: "My conviction is that all animals distinctly see in those of other species living, sentient, intelligent beings like themselves, and that when birds and mammals meet together they take pleasure in the consciousness of one another's presence, in spite of the enormous differences in size, voice, and habits."

Bird-friendships are no doubt common in bird-life, and would be more frequently noted, if the art or science of sympathetic observation were not in its infancy. Its day will come, and the naturalist who "bends to 
himself a joy" be replaced by the naturalist who "kisses the joy as it flies." But will it come too late? Such friendships are obviously more interesting than the commensalism that exists between the crocodile and the spur-winged plover, which is based on mutual selfinterest, though a kindly supererogatory sentiment may develop from it. How little we know of the psychology of bird-life! We know a great deal about the anatomy of birds-the principles of classification and distribution and the rest of it ; of their lives or their relation to one another, to nature, and to ourselves, we know next to nothing. ${ }^{1}$

The appearance of these waders out upon the inscrutable marshes is so vanishing, and their wild, bubbling, seemingly bodiless cries, often beautifully inflected, are so rhythmical, that it is natural to think of them as always in motion, and their motions themselves as figures in a dance.

There is a constant procession of thin shapes flashing across the vision, and little parties of birds dash over the ground like sudden inspirations too elusive to be retained -sanderling, ringed plover, redshank, whose plaintive, musical tuhuhu tuhuhu - the most characteristic among their several cries-is like the voice of some intangible, passing figure seen in dream. Even the bathing of these waders has a ceremonious grace, and being nymphs as much of the water as the land, they flirt little showers over their backs and curtsey their breasts into the water as though they glided from one device in the formal round to another. Once I watched a party of redshank bathing in a strip of pool, and suddenly one of them was taken with a frenzy of high spirits. Trailing feet, he hurled himself from one end to the other and back again, clapping his beautiful angular wings over his back and

1 That sound naturalist, Alfred W. Rees, who died a few years ago, writes in one of his books: "In those rare, brief intervals of outdoor study when, to my surprise and delight, I have caught a glimpse of what, for want of a better phrase, might be termed the humanity of Nature, I have not merely imagined, but have felt sure, that many of the finest feelings of man-pity, sympathy, devotion, unselfish comradeship-are shared in no small measure by creatures considered to be far beneath our plane of life." 
upon the water. Flight therefore is the supreme expression of the waders, the gathered up form of their restless movements on land, as a collocation of phrases, seeking a true outlet for the increasing emotion that urges them, finally runs into a metrical design.

Dunlin are the most striking of all the waders to watch in the air, for they move with that single and unanimous consciousness which, though it is confined to but a few land species-starlings, wood-pigeons (rarely), daws (in play), and skylarks (occasionally in the winter)-seems to endow them, and perhaps does, with a sense, a faculty unknown to us. In assuming that animals possess only the rudiments of our capacities, we are inclined to overlook the fact that they may possess developed ones of which we have only the fag-ends.

The flight of a cloud of dunlin is more rapid than that of starlings, and they appear to confine themselves more strictly to a limited area. When they fly thus, as though a definite space for manœuvres were pegged out for them, their dancing patterns in the air, brilliant turns and dashes, and the streaks of silver appearing simultaneously when they expose their white underparts, make the spectacle more beautiful than anything that starlings can give us. Finally, they will ravel out into a single line, and, with a lovely crescentic sweep, come to rest. But all the waders fly more or less in a band, and make a unified, perfect lyric of it. Many of them keep only a few inches above the ground, and their numerous curves and oscillations are performed with extraordinary dexterity on their sharply turned and pointed wings.

The redshank, too, has an individual action of the utmost beauty, throwing up the wings into an arch and displaying the white undersides just before alighting. But the ringed plover, always going just one better, repeats this action before taking flight, as well as before settling. It is curious to watch them thus arching their wings as a prelude to flight, in the same way as a diver raises his arms before the plunge. There is something deliberate and formal in it-like taking off one's hat before entering a church. It is a kind of propitiatory 
gesture, as if the bird invoked the ether to bear him lightly on its bosom.

I have seen the velvet scoter in East Anglia, a diving duck handsomer than its far more numerous relative, the common scoter, the white speculum giving a fine glossiness and depth to the jet-black of the rest of the plumage, perform the same action. The gesture is made before diving, and as the bird often remains under water for nearly three minutes and reappears a hundred yards away, it is appropriate that he should, so to speak, preface his achievement. But it seems more than that. The wings are lifted and arched as though in invocation to the nymphs of his second element, and the pose carries the mind back to some ancient fresco in which a countryman holds out in his extended arms a sheaf of corn before the shrine of Demeter.

Now and then one would catch one of the waders flying by itself, usually a little stint, drawing mazes upon the air almost as masterfully as the snipe, in its irregular twists and doublings. But the flight of most of the waders is a social function, and there is yet another glory in the sanderling's flight, for as they pass through the air they swing their bodies from side to side, now displaying the greyish umber of the back and wings, now the pure silver of the underparts. Thus there is a double harmony in the process of flight, the rhythm of the wing-beats being varied and interwoven with the sideto-side motion of the body, like a repeated refrain in a poem of a different metre from it, except that the variations are telescoped as they cannot be by the most skilful metrical technique. Or rather the flight is less a poem than a choric song. This see-saw action is peculiar to all the small waders, though sanderling, and particularly dunlin, are more highly specialized in it. A flock will suddenly be completely blotted out as their backs turn towards you, reappearing again in a gleam of silver, and once again becoming invisible. The elusiveness of all these small pipers, the rapidity of their flight, and the discipline of their manœuvres over the desolate plain, create the impression that they are not birds at all, but aerial spirits visible in a silver radiance but at moments to mortal sight. 
I doubt whether I have anything like compassed the charm of these shore birds-so shy, so volatile, so difficult to approach and distinguish, and yet so appealing that to slaughter them as they are slaughtered all along the coast and all day long seems as abominable as shooting fairies. Not that it would make any difference if they were. There yet remains their shape, their poise on their slender stilts, balanced by the length of the bill, and forming a singularly accomplished artistic design. They are like a lily or a daffodil gathered with its whole long stem. A violet is lovely of itself, but it does not possess the satisfying element of long line. The heron and stork share this grace of line, and the shore birds, from curlew to little stint, have it to perfection, and are so decorative with it that one realizes more fully how very well the great craftsmen of the East knew what they were about.

Then there is the romance of their inaccessibility. We can climb trees, but we cannot walk on mud flats. Thirdly, there is the wonderful pencilling of the plumage. In the plane of form, the legs are of the frailest compatible with use, and body, bill, throat and general shape follow slender lines in musical conformity with them. In the plane of colour, the tones of the delicate centres and margins of each feather merge into pale, subdued browns or greys, themselves relieved by vivid smears of black, white, rufous and chestnut. Without disparaging other birds, these waders did seem to me to represent the most essentially perfect bird-form I have seen, perhaps the only bird-form that would look well out of its natural surroundings. That is saying a good deal, for birds are symbols of our concepts of ideal beauty, and the loveliest flower is a poor thing to them. Would that I might have been a disembodied spirit for a space, to fly invisible among them and witness every little thing they did, even the flowering of every wayward thought and caprice in the great sum of them that has mounted with every falling sun!

It is intriguing to ask whether these wading birds are in any way conscious of their own or their neighbours' beauty. In a way, the question is unanswerable, for we 
cannot see far into the recesses of the bird-mind. But it is capable, perhaps, of a qualified solution, partly by particular and partly by general application. In the first place, there do exist certain examples of æsthetic appreciation among animals. The bower birds make a decorative front-garden to their homes; bees visit flowers not only for their scent, but their colour, and Forel's experiments show that they return to objects of the same colour as the flowers whose nectar they collect; moths are attracted to white flowers in the dusk; magpies steal bright objects; a surprising number of species decorate their nests with flowers, and so on. But sexual selection is the most important example, so important that Herbert Spencer derived the whole stimulus of the æsthetic sense from the sexual emotions. I am assuming that Darwin's theory of preferential mating stands proven-it is accepted by most biologists-and that whether the hen-bird's interest is emotional, or æsthetic, or sexual, the one must and does imply an infusion of the other two. The male on his part displays his plumage to the best æsthetic advantage, and follows a kind of informal, rhythmical design in his dancing and posturing. A certain æsthetic awareness exists, that is to say, in both sexes, and its selective interplay has a high survival value.

The general question views the omnipresence of beauty in nature and wonders how it got there. For natural beauty is the normal expression of natural life; ugliness we only find in a very rare monstrosity or in parasites, which have gone to the bad. "The pismire and the egg of the wren, each is equally perfect," says Whitman. "The halo of beauty," says Professor Thomson, "is on every free individuality," and he quotes Lotze: "To look upon beauty, not as a stranger in the world ... not as a casual aspect ... but as the fortunate revelation of that principle which permeates all reality with its living activity." The ugly, the inharmonious, the discordant have been eliminated as unfit in the struggle for existence. The next question is how did beauty arrive? and the answer is by that complex power of differentiation we call evolution. At one period in the 
world's history beauty, we may be sure, was only rudimentary and potential ; it was developed from humble beginnings, just as the idea of God has risen from fear and utilitarianism to its modern nobility in the evolution of man. "There is a grandeur," wrote Darwin, "in this view of life, with its several powers having been originally breathed by the Creator into a few forms, or into one, and that while this planet has gone circling on according to the fixed law of gravity, from so simple a beginning, endless forms, most beautiful and most wonderful, have been and are being evolved." Beauty was in fact evolved concurrently with psychological and ethical factors, and that is why a really beautiful thing is at the same time good, true, and individual. If Nature is beautiful, that is to say, there is a religious meaning in the evolutionary process. Art is religious, says Mr. Clutton Brock, "because it makes us believe in the goodness of God and the kindness of the universe He has made."

The animate world as we know it has, then, been evolved from an infinite number of variations, and these variations originate in the germ-cells, which are not simple protozoa, but "unified individualities"; which " experiment internally, not fortuitously, but artistically; not at random, nor yet inexorably, not purposefully, but perhaps purposively." Change or evolution, that is to say, depends upon the inborn creative power of living creatures, and variations (which we might just as well call inspirations) are what Professor Thomson, with insight, calls "experiments in self-expression." Variation is a progressive series of experiments in ideas, manifested, with all its failures, all the throwing aside of unfinished drafts which we call the elimination of the unfit, by the growing individuality of more and more complex living creatures, in that conquest of mind over matter, and the freedom of personal choice harmoniously embodied which make the works of art. Beauty, that is to say, is not only the actual, but the inevitable consequence of this process; beauty which is "Nature's stamp of approval on harmonious individuality." In this sense, therefore, we can surely say that living creatures take a hand in the creation of their own beauty, 
and that æsthetic pleasure, whether unconscious or (in the higher animals) dimly conscious, exists throughout the whole of the animate universe, from the Foraminifera's instinctive choice of the right materials for building their shells to the nuptial display of the Argus pheasant. It is possible to believe that an artistic awareness does exist in these wading birds, if unformulated and expressed in their actions, rather than in the conception of an imaginative kingdom outside their own, which is the prerogative of man.

\section{II}

I am tempted to make a digression here. The flats round Blakeney are the property or rental of the "National Trust," but shooting "for food" is permitted, and this, of course, drives a coach and four through the law, with the collector of rare birds driving it.

But, it may be argued, would you interfere with killing these birds for food altogether? Certainly not, if they were needed for human food. There is no such necessity at Blakeney, and, as Mr. Edmund Selous wisely says, "The killing of any being, not merely of any human being, can only really be justified by the strength of the reason for doing so, i.e. through necessity." He adds further on :-

"When we think of the pain which is often inseparable from the act, of the well-being and happiness, the affection, the tenderness even-experto crede-which, by it, we destroy, and of the absence of all crime and wickedness in those non-human lives thus made to cease, reason, no less than morality, must tell us that such necessity ought by no means to be lightly admitted."

The gunning tradition, in fact, has outlasted its usefulness, with the consequence that what was once justified as a need cannot, when it involves the slaughter of harmless and richly endowed relatives of our own (many of them no bigger than thrushes and sparrows), be justified as an amusement. A use has degenerated into an abuse of our power over creatures endowed with our own warm blood, but not with our developed understanding and capacity to take care of ourselves. "They that have power to hurt and will do none"-how little is realized 
the scope of the natural historian, that his business is with the universe, of man no less than of all other animals, and that the fallings from grace and selfrespect of the one are no less his concern than the destruction of the others. "Lilies that fester smell far worse than weeds.".

\section{III}

I have said elsewhere that birds in masses possess a special artistic virtue, and the flats offer peculiar advantages for so seeing them. A common sight were clusters of herring gulls about a ploughing team a few hundred yards inland-a shower of white bird-marguerites resting on the dark furrows or bird-butterflies fluttering in the very steam of the toiling horses. I say common, because there can be few Englishmen who have not seen it throughout the length and breadth of the land. It is a sight intensely native and particular, and I can imagine no memory one would sooner retain in exile or even in death, no more satisfying symbol of the genius of the race than the ploughman's team with its escort of white birds. Yet, though common as a rainbow, whose heart can but leap at beholding it, whose mind but see in it a fount of mystery and legend ? Flowers sprang from the sod wherever Aphrodite set her feet, but not for her bloomed the spirit of wild freedom as it blooms and scatters its petals in blessing over the heads and in the tracks of straining horses and simple labouring men, fulfilling the earth. Should man ever find his senses and plough a straight furrow into the future, may the white birds be strewed upon his path, thoughts of his advancing mind and stars of his true courses!

I remember one gull-day in particular. The commonest species along the coast was the lesser blackback (though the herring ran it close), and they were always wandering on yellow legs over the grass and mud or flying over one's head uttering at intervals their gruff, hoarse orok orok, or hah hah, like the muttering of the wilderness. On this festival day there were gathered some four hundred or so birds, resting on 
the mud and facing one another in two long lines. The blackbacks were greatly in the majority and were all facing one way, head to wind, as is usual with gulls, and in the manner of lapwings and fieldfares, producing a strong effect in their alternating blacks and whites. Then one great mass rose up, as it seemed, and possibly was, by telepathic suggestion, by a sudden rushing wind of common impulse, made a half-circle and joined forces with the other, creating such a confusion that the whole multitude was lifted ponderously up, and out of the cloud came threading the herring gulls like strands pulled out of a skein, their silver-grey wings gleaming in the level rays of the sun, and leaving the black volume to come foundering down again upon the yellow sand. Why the two species thus separated I cannot pretend to guess, but enough for me were the power and grandeur of the spectacle. Had the species been blackheads, the sight would have been less impressive, their flight being much less steady and determined.

A minute later, seven goldfinches rose out of the thistles growing alongside the turf-banks, in no wise less beautiful than the gulls, but displaying their refinement and elegance in nature's shop-window, as though she were a kind of Whiteley's, advertising simultaneously things impressive for their splendour and appealing for their grace-except that the purpose of the one is money, of the other only life and beauty. The blackbacks were in the habit of pursuing the smaller gulls (blackheads, and perhaps "common," practically indistinguishable in autumn and winter) in the same way and apparently with the same object as skuas pursue terns and other species. It would be worth while finding out whether the bigger gulls-notable poachers-are not sometimes experimentally parasitic upon their weaker cousins in the skua manner. Skuas have specialized in this form of commercialism, but there is no reason why they should not have apprentices. ${ }^{1}$

Another impression of volume was a flock of about a thousand starlings trailing high up above the pastures like a black, stippled cloud. They were not at their 1 See p. 112. 


\section{BIRDS OF THE COUNTRYSIDE}

exercises, but came across the sky to drift and sag down among the cattle. They were obviously migrants, and this was corroborated by further detachments flying from north to south to join the main body, until there must have been nearly two thousand birds picked out against the ground like a field of black flowers. The birds were tired out, and kept straggling in, dragging a heavy and a weary oar, and dropping with relief into the cool pastures.

Larks, too, were beginning to collect into their autumn bands. One day I saw about thirty of them within a quarter of a mile, feeling one another's presence as it were, tasting the sense of contact before signing the bond of association. The songs of these larks were very interesting. The birds rose up from fifty to seventy feet, and there hung suspended, fluttering their wings and throwing out slow, laboured and disjointed notesfrozen stalactites rather than a cascade of melody. Occasionally, the superb trill leaped out of this toil and tangle of guttural chords only to fall and be lost among them again. The curious painfulness of the whole performance reminded one of nothing so much as an academy of music. Certainly there was nothing rapturous nor unpremeditated here : these were pupils of the lark school, not blithe spirits and "etherial pilgrims." I hardly attempt to explain this, since, though the year was at the fall, larks in full voice were occasionally to be heard. I can only surmise that this was a party of birds collecting for partial migration. The young had left their grassy cottages and gone into the world; the sun had climbed so far above them that he could not warm them, much less they visit him; the Norfolk larder was running bare, and the east wind getting into their throats. ${ }^{1}$

A curious feature of the flats is the variety of inland birds which visit them in the autumn, either on partial migration or on foraging expeditions, or simply, as it appears, for a change of air and locality. The population of shore as well as inland birds is even more shifting, and this great open waste may be likened to a railway junction or a busy seaport which is a place of call on a

1 The reason, I expect, was a physiological change corresponding with the change in the seasons. 
thriving trade route, where merchants, sight-seers, speculators, adventurers and natives mingle in a common throng. One's eye will turn to the linnets bounding through space with fairy chimes, intoxicated by the pure sharp air, and sometimes one bird pursuing another in a playful ecstasy of love. From them, it will perch idly on a patch of thistles and not perceive at first that the little balls of down travelling upwards, as if starting a handicap race, are set going by a First Cause, a Primum Mobile - a pair of goldfinches swaying, fluttering, "waving their wings in gold," as Horace Walpole (a true lover of animals) says, on the thistle heads.

Once, not thirty yards from Blakeney Quay, I caught sight of a male siskin perched on the bank of a small creek among the herbage. There could be no mistake, for the sun shone full upon his greys and greens and the black and gold wings ${ }^{1}$ (exquisite together both in nature and in art); and I was but twenty-five paces away. But what did a solitary siskin on a stream's bank in this treeless wilderness, swept by the bitter east wind ? Some hardy and adventurous navigator, planting the siskin flag on a new continent, or a tired traveller, separated from his kin, a castaway dumped upon this sea of brown slime and marsh by the rough wind? It is curious how single visitations like this impress themselves upon the mind. On the banks of the Suffolk Alde I remember once seeing a single dabchick in the river, a single goldfinch feeding on a thistle head, a kingfisher rushing down a muddy creek (a pearl in an oyster), all within a couple of minutes, and then a few minutes later a solitary young red-backed shrike perched on a bush two yards away (it was the 7th of October, and its parents should have settled down in Abyssinia many days before). Whether it was the strangeness of this last sight or the contrast afforded by a flock of widgeon passing me in full whistle soon after, ${ }^{2}$ this experience-

1 The winter colouring is olivaceous.

2 It is a liquid call, and not unlike both the low and fluting call of the sheld-drakes to their mates in the breeding season and the cry of the stone-curlew on the way to their feeding-grounds in the dusk. 
a necklace strung with four bright beads-has ever afterwards remained as clearly impressed on me as on the day it happened.

Small flocks of wood-pigeons used to feed on the saltings, and hordes of rooks frequently perched, sometimes with a kestrel or two perched near them, on the telegraph wires. It is possible that in the event of the disappearance of our woods, the rooks would still keep a hold on existence, so extraordinarily adaptable is the crow tribe to changes of condition. Ropes of starlings, too, were to be seen on the wires in hundreds, each strand a living, sentient, intelligent being, whose lustrous. plumage seems the index of the fire of life burning within.

At Holkham, in the ugly, formal avenue leading through the marshes from the Leicester estate to the sandhills, I saw something I had looked for a long time in vain. It was a wandering party of eight long-tailed tits, waving their tiny wings as they passed by short stages, and a pretty switchback flight from one bush along the drive to another. When they alighted before travelling on again in single file, they looked a soft white (the rose appears on the scapulars, flanks, belly and lower part of the back, and is not conspicuous) among the dark bushes, and the zee zee of their high, thin, stridulating voices (the family call-note of the tits, but shriller, weaker even than that of the cole-tit and altogether more insect-like) sounded incessantly, as their minute, slender, tapering bodies swung through the air. Here was a joyous thing, for the long-tailed tit, never so abundant as his four cousins, became so rare after the hyperborean winter of 1916-17, that, if he diminishes in numbers a little further, he will be doomed to the glass case. The collector will have him, that sham scientist and predatory clod who preys upon the misfortunes of beautiful living things and, let them once be rare, damns every bird to death.

The wild geese, which come to the coast from Norway in the autumn, I saw but once-on a golden-tawny spit of land about a mile from the Wells foreshore, and safe enough from the gunner to resume a pleasant social life. Wonderful tales are told of them. It is said that they 
know within a few yards where they are safe on the salt marshes (on the Earl of Leicester's estate) and where not; that they will pay no attention to a man with a walking-stick, but that the sentinels instantly warn the flock of the approach of the gunner at almost any distance away; and that on Sundays when no shooting is allowed in certain localities they will unconcernedly walk about with-my own interpolationderisive confidence in their immunity. According to Darwin, in the Voyage of the Beagle, the Fuegians could not be taught to connect the detonation of a gun with the death of an animal at a distance from it. It is well for the survival of the wild geese that they have learned the A BC of such association! Even the domestic geese (descended from the grey lag) retain something of their old lofty bearing and independence, and are far and away the most original and sagacious of homestead fowls.

* $\quad * \quad * \quad * \quad * \quad *$

Norfolk is indeed a monstrous fine country for birds, and the seeker has fulfilment of his quest thrust upon him. Does he tire of the mobs of pheasants in the woods, does the exclusive society of the flats keep him at too uncomfortable a distance-almost every house is a varied peep-show. I remember spending the night in the room of a beautiful old seventeenth-century house (with fine gables, clustered chimneys of brickwork in the Hampton Court manner, and a red-tiled roof with shingled projections) in one of the coast villages. Here I had a close view and a long view-indeed, the privilege was compulsory - of two jays, two dotterel, two corncrakes, a long-eared owl, a stone-curlew, a waxwing, a budgaree and a squirrel. The naturalist had but to sit in a chair and gaze on the birds performing characteristic actions in their glass hives like petrified acrobats. Why ever tear a thorny way through brake, through briar? Why spend ten guineas on a field-glass? Why invite lumbago in a bog? Why trouble to read Shelley in the original when there is Matthew Arnold's criticism?

The sitting-room I had included other objets d'art besides the birds, and the collector had mobilized such 
a variety of styles and periods, and with so princely a gesture of impartial munificence, that the spectator, transported by this generous display and superiority to the anthological principle, could but exclaim-he nothing common did or mean upon this memorable scene. Among the infinite riches in this little room were massy sideboards and "escritoires" and mirrors and tables and chairs and fern-stands of sham oak elaborately carved and ornamented. One good cane chair and one good mirror stood making wry and selfconscious faces at one another amid the motley, and I admired the discrimination which could bring baseness and virtue into such close relations as to put a premium upon the charms of the latter. On the mantelpiece, old Sheffield candlesticks rubbed shoulders with china plates printed with Dana Gibson vignettes and large earthenware figures modelled from Pears' Soap originals. A huge sideboard of sham oak (carved and gilt) was heaped with plated cheer-old brass and pewter, ash-trays, sauceboats, old willow-pattern ware, etc., side by side with china vases and lidded pots in the "Present from Margate" manner. On the walls were portraits of music-hall entertainers and hair-tonic women, hunting scenes, antlers, and the glass-eyed birds grotesquely posed there in their faded plumage, and to their originals what the doggerel of an advertisement of boot-blacking is to a lyric of Dekker's.

The woman of the house was worthy of her household effects. Flesh and blood she may have been, but I saw nothing but a clockwork statue for movement and a mechanism for a voice-an inflexible voice with no ups and downs in its career, but plodding along an endless, flat desert of correct utterance, with never a bush nor pool of water. She hardly thought her house, which received only "the best people," was suitable for the likes of me. Ah, dear lady, thought I, your anxiety to get rid of me does not, cannot equal mine to escape your cemetery and you, poor victim of a sacrifice of which you know nothing, but for which all of us of this generation and the ghosts of the past one are responsible and accountable! 
It was good to leave this domestic pillar of salt and see once more a grubby child sucking acid-drops in the road ; to leave cheap reprints for first editions again; and to hear once more the cry of the lapwing and the humming of the cushat, and to depart a county altogether whose record is kill and stuff, stuff and kill from first page to last.

But it is ill to leave this land of industrious Fleming and free-hearted Northman with sour feelings. A change is certainly at hand, and it is equivalent to the change that is taking place among naturalists. Up to the dawn of the twentieth century a naturalist was more or less judged by the number of birds or mammals of different species he could kill in a lifetime, and accordingly Seebohm, totting up the number of titmice he had shot in Siberia and Gätke, relating how he had "obtained" sixty bluethroats in full plumage on a May morning, were the Dioscuri of the ornithological Pantheon. But the mortuary notion of excellence in Natural History is now discredited, though as yet without seriously checking the extermination of rare species by the predatory naturalist. Progress there is, and one way of detecting it is to observe the process among individual naturalists in our own generation. Many naturalists (J. K. Job, the American ornithologist, Mr. Edmund Selous and Mr. Patterson of this same Norfolk, are distinguished examples) have discarded the old, bad tradition, and been converted from the gun to the field-glass. It is indeed worthy of note that men like these, emerged from the pupa stage of Natural History, rather than the professed "humanitarian," attack the destroyers with the most bitterness. Paul, after all, is the very best judge of what Saul was. Therefore, there is a kind of savour in the literary works of these "converts," a reality given poignancy by occasional outbursts of heroic self-loathing, absent from the writings of other naturalists, who, nurtured in more civilized and philosophic ways, have never known the temptation to use a gun or keep an "aviary." It is pleasanter and trucr, then, in leaving Norfolk to think of Mr. Patterson and to reflect that what has taken place in him with such lofty credit is surely, if slowly, affecting his fine countrymen. 


\section{CHAPTER III}

\section{A GITY OF BIRDS}

I

THERE is only one mediæval town in England, and 1 it is, of course, in the West. It is mediæval not for historical nor archæological reasons, but because it is a town in the country, gently lowered down, all readymade, into a cup of the wooded hills and there left. It is an island of stone washed by the green seas, thrusting out capes and promontories so little a distance from home that five minutes' walking from the market-place to any point of the compass takes one right out to sea. The town is true to itself, the country to itself, and the neighbourliness of both is nowhere broken by the mongrel suburb, which, being neither town nor country, is false to both. There is no other town in England (with the possible exception of Bath) where this clearcut distinction, this Düreresque feeling can be properly savoured. The town, apart from its cathedral, the great stone jewel in its casket, is like an old religious poemmatter-of-fact and mystical, precise and romantic. It is a "thing that you may touch and see," yet not of this world.

In it and all about it live the birds, as they will live about a farm-house in far greater numbers and variety than in the open country, waiting for the truce that never comes. In no other part of England, whether pasture, salting, heath or woodland, have I seen the birds so abundant, confident and varied, as in the streets, the cathedral precincts and the pastoral borders of this changeling town.

I have lived in the little town both in spring and in autumn, and can no more choose between them than between Comus and Samson Agonistes. For autumn, like 
spring, is a time of preparation, and if the one garnishes, the other sweeps the house. Spring writes the prelude to summer, autumn stores its material for spring. "O wind, if winter comes, can spring be far behind?" The poets are so often the prophets of biological truth, for the wind scatters the seeds. Autumn is indeed at once prodigal and provident; the balance of life is being spent, only to be invested for the future. Spring is not always a "faerie's child," and autumn is a burning bush, so much an image of intense life that one cannot believe it will be consumed. Here is an account of a spring visit in which age was strangely mingled with youth and beauty with ugliness. There is a wonderful place some half a dozen miles from the cathedral town. It is famous for yet another cathedral, not built with human hands, with its pinnacles rising out of the massive, battlemented rocks three hundred feet high; its parapets, gables, screens, arcades and canopies cut by the First Architect out of their own element, and the carvings and traceries-the grace of strength, the delicacy of grandeur - the ivy, hawthorn, mountain ash and creeping plants that lace the sheer walls. This cathedral is hewn out of the limestone cliffs, once, no doubt, the walls of a sea-cavern whose roof fell in with the action of the sea-waves. Its graveyard, or cloister-garth, if I must speak more elegantly, is economically built into the walls, since the limestone is a conglomerate mass of petrified life, a vast biographical museum of a world which had not yet conceived the sombre idea of man. Before the deep gorge, with the cliffs soaring on either side, is reached, one passes through a straggling village, and beyond it come the caves, plastered over with tin shanties, refreshment booths, advertisement posters and a loathsome white pagoda conspicuous for miles round. On the other side of the street runs a dirty little mud and bottle-encumbered brook, occasionally broadening into pools, so that on one side we have Victorian picturesqueness a little damaged, and on the other a transplanted Earl's Court Exhibition-two civilizations nagging across at one another their superior advantages. 
Then suddenly round a corner towers a third, which will remain when these showy little fellows have passed away, and stood there, impregnable and lofty, æons before the worthy of river-bed type, whose skull reposes in a glass-case, making money for a more up-to-date society, chiselled and polished his flints on the floor of the cave, that knew not, as it does now, electric light. Here were absolute solitude and a kind of keyed-up, concentrated silence, broken only by the bright voices of the daws, whose cries, made metallic and almost shrill in the hollow between the cliffs, went spinning and leaping from crag to crag. The contrast between the one scene and the other was theatrical, the imperious, precipitous rocks seeming to frown down upon the dwarfed face of our mean, gimcrack, competitive modernism and to make it piteous, like a slum-child with a cross-grained leer.

When I walked up the gorge in spring, the shrubs and ivy and minute trees were clothed in their first tender leaf, as if the solid cliff had blossomed, and their fragility and delicacy of form and colour against the gaunt walls of grey, primeval rock were so beautiful that "the sense faints picturing" them. Gazing upon this miracle and thinking of the huckstering going on fifty yards away, a portrait in little of man's general defilement of the world, one could not but be tranquillized by the assurance that treasures of loveliness lie dormant in the hard heart of man, and that they will one day sprout like the "glad light grene" from the face of this bare rock.

I was disturbed from these sentimental flights by a more material one-the flight of an old friend of Neolithic man, the hero of so many dark legends, and doomed very soon now to reside like him in a glass case. The rockchurches of nature are now almost everywhere sacked of their ccclesiastics-raven, kite, buzzard and eagle-and one has to be content with the choir-boys-kestrel, daw and pie. Yet this cathedral had its attendant priest, for the raven was nesting not a hundred yards from his human prehistoric contemporary. The nest was two hundred feet up the rock in a natural cleavage, sheltered above by overhanging boulders, and projecting over the platform-inaccessible, one would have thought, 


\section{A CITY OF BIRDS}

even to the collector who is always so ready to break other people's necks to fill his cabinets with egg-shells. Though the birds were sometimes five hundred feet above me, the beat of the wings was always audible, and when they half-closed their vans and dropped a hundred feet sheer before catching themselves up by a rapid shooting out of them, the noise was like a wind. Now and then both birds alighted on the bluff opposite their nest and caressed each other, the male locking mandibles with his mate and swaying gently with her, or nibbling at the hairs at the base of her bill with caressing murmurs, fondling sounds totally different from his normal voice. They were seldom silent, and while the hen bird was on the nest, her mate floated above the cliffs with primaries outspread, like the fingers of a hand, uttering his loud, rumbling bark-growl-croaks, like a bishop reading the Litany. The sounds went tumbling down the gullies and against the bastions of the steepled rock, " ancestral voices, prophesying war."

There is something in us which responds to the raven in his natural haunts, as men with a great literature behind us in which he plays his grim part, because his aloofness and majesty are an expression in terms of life of desert places which owe nothing to us and our machines, and because, in the words of Taylor, the water-poet, he is "old, old, very old," older even than ourselves, who took our human form a million years ago. The tragedy of mankind is not a little thing, but it takes a belittling shape-and a tragedy without rhythm and dignity is a pitiful thing indeed. The raven is essentially a tragic bird, in his shape and colour, in the nature of his fastnesses, in his fierce temper, in his associations, and in the gloomy destiny he has suffered at our hands. But he is no more vulgar with it than the lonely places he inhabits, of which he is the living symbol, and the sight of him recaptures for us the commingled tragedy and sublimity of the human story. Outlined against the bluff, like a bird statue hewn out of night or the rocks of his home, he who has given so much dark inspiration to legend, tragedy, verse and history, drop down into the shadowy sea of twilight, himself a shadow, and, when 


\section{BIRDS OF THE COUNTRYSIDE}

he disappears, no longer even the ghost of an ancient memory.

As I came down the gorge I saw something which for grandeur and awe outpaced even the ravens. A few daws were sporting and soaring and dashing headlong like tumbler pigeons among the cliffs, when a great company of them suddenly rose into sight from the hills opposite me in a compact body-fully half a thousand of them-ringing out their crisp, detonating cries in loud unison. Then, with nothing visible or audible to account for it, they formed into a thick column so quickly that the eye could not follow the change of position, and hurled themselves obliquely across the ravine with such speed that the roar of their wings was that of huge breakers in a lofty sea-cavern. The experience was so extraordinary-the uniformity and precision of this precipitate flight, its incredible velocity, the tornado of cries from five hundred throats, the rush of five hundred black bodies across the sky, and the mighty thundering of the wings-that a botanist I was walking with, filled with the divine fire of having viewed a pink (Dianthus coesius) which grew in the gorge and nowhere else in Great Britain, shouted with the excitement of it and talked of nothing else for the rest of the way. Nothing but violent terror, or a rapture so intense as to demand a furious expression of it, could have caused so strange an upheaval.

So back from the surge and thunder of the daws' Odyssey to the rustic bridge, the white pagoda and the ginger-beer bottles. It seems a queer thing that we should have to pass through the one to reach the otherthat for the human mind to grasp the value and wonder of creation, its power and intensity and abundance, its manifoldness in uniformity, its intricacy in coherence, its flux and diversity in persistence and continuity, it must penetrate every ugliness and folly. But so it is, and such is the meaning of the progress whose tangle confuses us to deny it. We cannot know our gain until we have tasted the full bitterness of its loss: 
II

But I am forgetting my little town and its birds. At the end of March the blackthorn at the edge of the town is nearly over, and is as beautiful then as when its outlines are more definite. As is usual with the rose tribe, the petals have dropped off, leaving the innumerable white stamens, like the white filaments of the egret on a miniature scale, protruding from the corolla. The effect at a distance is as though the black twigs were wreathed in a luminously white spray or in scarves of mist which must soon evaporate upon the air. Approaching the cathedral from the fields, the grey stone screened but not hidden from view by a tracery of "glad light grene," I was like a traveller discovering some wonderful city of legend, and now that I have left it, the memories remain draped over my mind like the green shoots over the stone walls.

It is one of the more cherished of them that I found on the borders the first pair of whitethroats I had seen that year love-making on May 11th. There was the male, singing his grating, exuberant song in an abandonment of love and glee, swelling out his throat, flirting his tail, swaying his body, leaping into the air in a transport and somersaulting back to his twig. How different is his singing, which seems to sprout from the gesticulating body and the whole nervous fluid of his temperament, from the deliberate pose of the chaffinch, as he takes his stand on a bough and proceeds formally to sing his rivals down in that set flourish which Mr. Hudson calls " a musical sneeze"!

Bird-watching is full of surprises, and I fancy any moderately competent observer could, in the course of years, collect enough facts about the habits of birds to place against most of the text-book information that denies them. Not that the text-books are wrong. But the fact that one compiler in his study is apt to take upon his shoulders the generalizations of his predecessor; that nature will not be cut to the measuring yard, and that the observation of birds unharmed and in their natural homes is a comparatively new 
science should make one wary of the hand-book. Thus I watched a willow-wren building his nest on the top of the magnificent old wall surrounding the bishop's palace, all festooned with plum, cherry and peach blossom, as if he were doing the most natural thing in the world, and not (as he was) violating ornithological propriety.

In or near the garden itself, surrounded by a moat and forming with its wall an annexe to the cathedral buildings-redstart, blackcap, garden warbler, willowwren, chiff-chaff, wren, robin, spotted fly-catcher, treecreeper, pied wagtail, greenfinch and chaffinch all nested, while just outside, the grey wagtail, the pearl-grey and sulphur-yellow Ariel of the moorland stream hatched and reared a party of young.

One day I went off birds-nesting among the pastures and woods that frame the town, and in an hour I found a blackbird's nest in a copse with four eggs, a wren's in a faggot of wood with five (when I returned in the autumn I found the faggots gone-what should I feel like if a giant hand came down upon my home and, regardless of my cries, wrenched it from the ground, carried it off, broke it up and cast it with all its inmates into some gigantic furnace? But perhaps the little wrens took the hedges in time), a starling's and a yaffle's in the trunk of the same tall birch, a blue tit's in an oak, a crow's (positively a crow's, the most persecuted bird in England) with four young on the top of a hedgerow elm, and another blackbird's in the fork of a thorn on the banks of the stream a mile from the town.

The hen-bird of this nest was sitting, and with perfect devotion and gallantry never moved except to turn her anguished eyes from the wide fields, the flowing water and the sprawling hedges, symbols of freedom, of security, of life itself, to me peering at her not six inches from her bill. This was a surprise to me, for the blackie, the Miss Bates of bird society and the least intelligent of the thrushes, usually betrays the nest by flustered exit and loud alarm-cry more readily almost than any other bird. Now, it happened that the dusky brown of the bird harmonized so well with the dim, neutral tints of her home, and the nest was 
so securely guarded on the land-side from prowling fox, weasel or cat by the interlacing branches of the thorn that both herself and her charge were safer where they were. Here is a relevant passage of Mr. Hudson's :-

"The instinct which in character comes nearest to that of the parent simulating the action of a wounded and terrified bird struggling to escape in order to safeguard its young, is that one, strong in a ground-feeding species, of sitting close on the nest in the presence of danger. Here, too, the instinct is of prime importance to the species, since the bird by quitting the nest reveals its existence to the nest-seeking enemy.... By leaving its nest a minute or half a minute too soon the bird sacrifices the eggs or young; by staying a moment too long it is in imminent danger of being destroyed itself. How often the bird stays too long on the nest is seen in the corncrake, a species continually decreasing in this country cing to the destruction caused by the mowing machine. The parent birds that escape may breed again in a safer place, but in many cases the bird clings too long to its nest and is decapitated or fatally injured by the cutters. Larks, too, often perish in the same way."

But here it was the other way round, for I must assume that the blackbird, for all her fear, was aware of her security. Otherwise, why did she break her habit? For the instinct to fly the blackbird had rightly substituted the intelligence to take advantage of special circumstance, and stay where she was. Her instinct here, that is to say, would have played her false, where in other circumstances it would have preserved her. Devotion and policy were here at one, and the incident or lack of it was a striking example of a bird's power of breaking responsively away from fixed instincts on the one band, and of the marked individual differences in character among birds of the same species on the other. This, too, from the more routine-bound female. For birds to most people are what the Restoration plays are to me-I cannot for the life of me remember one plot from another.

But if there are examples of intelligent departures from instinct in the domestic behaviour of birds, there are others of stupidity. In an unkempt hawthorn hedge, throwing out long shoots into the adjoining pasture, I found a chaffinch's nest with three eggs in it-fleshcoloured in ground colour with a faint bluish tinge and 
mottled with spots of blood-purple-an architectural masterpiece woven of moss, strengthened with small twigs, dried grasses and wool and sprinkled with lichen, the lining being made of feathers, vegetable down, and horsehair. It was fixed to a horizontal branch three feet from the ground and at least two from the body of the hedge, so that it was clearly visible some distance away. In the long grass at the foot of the same hedge thirty yards away there was an ingeniously concealed chiff-chaff's nest, which I should never have discovered but for flushing the sitting-bird, which perched near by, wailing the anxious hui, hweet. When I was parting the grass I made a clumsy movement, and to my regret disarranged the upper part of the dome. I retired, thinking it would be better to leave repairs to the builder -ne sutor ultra crepidam - and hoping all would be well. I returned an hour later, and found that she had perfectly re-thatched the roof of her hamlet.

Blackbird, chaffinch and chiff-chaff taught me a good deal that day. When a rook drops a mussel on the rocks, it is acting intelligently, perceptually, with a definite and conscious end in view. When a bird builds a nest, it is acting instinctively, upon "unconscious memory," and spending its ancestral gains. The end is perfectly, but not (so far as we know) consciously. achieved. The bird is obedient to a passionate germinal impulse. But the choice of nesting sites brings individual as opposed to racial, and intelligent as opposed to instinctive faculties into play. Complexity both of conditions and of needs, a nexus of problems, fluctuating from year to year, confront each separate pair of birds, to be met and solved only by intelligence, or at any rate, intelligence working upon a ground-plan of instinct. $^{2}$ There can be little doubt that Bergson was

1 In fact, the only difference between the rook's and man's noblest behaviour is that the one has a concrete, the other an abstract end in view.

2 In Sussex this year, for instance, the trees on which a rookery was situated were cut down, and the birds promptly built their nests and raised their young in rabbit holes. Sir F. C. Gould told me of a nightjar which hatched two young among the shingle on the Devonshire coast, the protective resemblance 


\section{A CITY OF BIRDS}

right when he described instinct and intelligence as upon divergent tacks of evolution. But the point is that they intcrtwine, and never more closely than in nidification. Once the nesting site is chosen, then instinct operat ss upon the ground-plan of intelligence. But if there is a spice of instinct in choosing the site of the nest, so there is a spice of intelligence in building it, since the bird can and does meet circumstances which break the routine and experiment (as sometimes happens) with new materials. It was intelligence, not instinct, which this chaffinch lacked. In prospecting for sites, activity is chiefly unpredictable and indeterminate; in building upon them, fixed and regulated. Or, to put it in another way, the present trains the cannon, the past charges it (viz. directs the bird how to build its nes," and the present discharges it. Nidification, I am sure, is an example of the most delicate interaction of instinct and intelligence.

Blackcap and garden-warbler sang almost side by side in the steep wood fronting one angle of the town, the softer and thicker rush of "pettychap's" fairy music contrasting with his congener's "full, decp, sweet, loud, wild pipe," as White described it, while the tremulous sighs of the wood-wrens not so high up among the "melodious greenery" as they get later in the season seemed to express pleasure at the privilege of enjoying these.two princely warblers beneath its fresh, bright canopy. It is not often that garden-warbler and blackeap can be heard in close proximity, for the former (it may be) seeks to avoid any critical comparison of his melody with that of his more brilliant cousin. In quality and general likeness there is very little difference between the two songs, though the garden warbler's is more sustained; in the manner and spirit of delivery the birds are poles apart. The gardenwarbler is a more approachable bird--I have watched him singing and flitting about in my sight for half an hour at a time-he sings more frequently, and his lay is of a soberer colouring. In the blackcap's song there

of the eggs and young to the shingle being, he said, as perfect as that of terns. Here initiative, experiment and intelligence were completely justified of instinct. 
seems the desire of something uncapturable, and so an impression of something unachieved-the goal of all poetry and religion, human and natural, which is never reached. His cousin sings a more routine music without fieriness of heart and within his own horizon. It is appropriate, therefore, to be able to see the garden warbler easily and the blackcap with difficulty, and that the one seems to shun the presence of the other as the more inspired master who outshines his domestic fire. They sometimes, however, sing together.

If summer is the fulfilment of desire, spring is the ardour of the year, and the greening earth seems to ferment with melody, which bubbles into a confused shrilling when the young birds begin to shout for food. An oak-wood near the town was so thick with young starlings that one might almost imagine the trees were made of metal leaves beaten thin, susurrating together when the wind stirred them. In the diffused chorus of more familiar songs and calls, so copious in favoured places that the air seems to vibrate with them, it is a rare pleasure to catch the notes of less common birds. A pair of long-tailed tits disport themselves among the branches, their minute bodies drifting through the trees like animated balls of down, come away with a long black stem, and the male now and again throws out a low and tender call to his mate, different from the insect-like zee zee of more prosaic feelings. I have heard the wryneck, a rare bird in the West of England, in this wood (on April 2nd), but I have never seen him there, his mocking, penetrating, mysterious puy, puy, puy enticing me on to seek his richly-mottled form in vain, like a horn of Elfland tempting a lost traveller into deeper and deeper recesses of the forest. Here, too, the nuthatch pealed out his clear tui, tui, and I have been so lucky as to have eight or nine jays passing over my head in the crowns of the trees, uttering a subdued and more musical version of the familiar scream. They were all in great excitement, and were, I expect, on their way to one of their spring concerts. Until nesting operations actually begin, jays are rather more than less social in the nuptial season. 
Emerging on to the open uplands from these bowers of song and flower, I could for a week on end be sure of both seeing and hearing a family of woodlarks living on the grassy borders of another wood. Seen close at hand-and they showed an agreeable unconcern at my presence-woodlarks can easily be distinguished from skylarks. The body is smaller and not so slender, the crest rather more elongated, the colouring of a richer striped and mottled tawny, the tail very short, and the whiteish eye-stripe more strongly marked and joining at the back of the head to make a diadem or wreath about the crown. There is also a patch of white at the edge of the wing, which skylarks lack. When alarmed, the birds take at opes to the trees, and lead a double life between them and the ground, feeding, nesting and (I think) roosting on the latter and singing in the former or in the air. The flight is swift and wavering, and, unlike the skylark, the birds singing soar the sky in spirals, but do not climb so high, partly, no doubt, owing to the shortness of the tail, which throws a heavy strain on the wings. The song, which I heard every day, is more reposeful than the skylark's, as is the general temper of the bird, purer and more intrinsically beautiful, though less so in association. It is freer of guttural notes, less overpoweringly joyous and ringing, and more in the notation of a clear, fluting warble. The melodious call-note-ulu-has a strange, melancholy spell of its own. There were five of this uncommon species, and the parents must have nested in the neighbourhood.

This park-like down of alternating wood and pasture, where the yellow umbels of the tufted horseshoe vetch (the only British species) bloomed profusely among the violets and yellow rock-rose, sloped down to the cathedral, and within view of it I have seen both the greater and the lesser spotted woodpeckers, the latter only once, and indeed but for the second time within memory. Kestrels used to spiral up the sky on the higher ground, travelling upwards at great speed and with rigidly extended wings. The spiralling of hawks is really air-tacking, and a sailing boat moves through the water and a bird soars through the air, the one by 
an intelligent, the other by an instinctive adaptation to the law of the parallelogram of forces. But the kestrels also took advantage of the upward tilt of the wind which occurs in hilly country. Large birds save themselves an exhausting expenditure of force by their instinctive meteorological knowledge. Meadow-pipits were abundant on the plateau, and I had many opportunities of watching and hearing them sing, a necessary correlation, for they leap from the ground and descend upon expanded wings and tail (which is cocked) in a slanting curve from forty or fifty feet in the air, the notes running more and more rapidly together as the bird nears the ground. It is not a champion's song. but is beautiful in its suitability to the wide expanse of earth and sky where the bird is at home and winds are abroad, and in tone is itself like the wind among seeded grasses. And this fitness to environment can be pursued further. The delicate birds and the fragile upland flowers were to the down what the traceried carvings are to the cathedral pile and the lyrics to the great substance of Shelley's Prometheus.

In the spring before the visit I am relating I neither heard nor saw a single bullfinch, but this year I could leave the woodlarks and pipits of the open for the bullfinches of the shades almost as assuredly as I could leave the trefoils and rock-roses for the wood-anemones, as lovely closed as open, for in dull weather they are like white globes lit inwardly, so transparent are their fragile petals, many of which are faintly dyed with a delicate pale lilac, and a few-fairest of all-with sky-blue. I remember once that while walking among the woodlands, there suddenly burst upon me the voices of all the outcasts and gipsies among the birds-the growling caw of the crow, the exhilarating shrieks of jays, the chattering of pies and the distant chanting of wood-owls. Gradually they fell silent, and then in the quiescence of nature, her indignation stilled, I heard a few feet away in the hazels the low, intimate wind-music of the bullfinch. The change of mood was extraordinarily dramatic, but the soft plaintiveness of the notes preserved the continuity of the experience and retained its significance, while introducing a consoling variation upon it. 
A red-backed shrike had his pitch near the town, and was generally to be found perched boldly on the topmost twig of a hedgerow hawthorn near a wood, swaying in the wind and turning his alert little head to all the points of the compass. Then he would suddenly drop down from his perch in the manner of the fly-catcher and hurl himself upon a crane-fly on the top of the meadow-grasses and then back again, the robber baron surveying the countryside from the lookout of his stronghold. I never found his skewered larder. But charming bird as he is in his soft grey, cream and chestnut livery, with a conspicuous black stripe (like a pirate flag) over his eye, he looks all the bold, bad villain of the piece. So confident, even disdainful was my bird, that he allowed me to creep within half a dozen yards of him with very little trouble.

Indeed, the one defect of this bird-showered land was that there were no nightingales. According to the tales of town and village they swarmed, and I frequently had their songs pointed out to me by local experts. But that year they were all temporarily occupying the forms of robins, wrens and thrushes. ${ }^{1}$ But the bird-watcher does not hope over much, for being wise in his generation he lives upon things not expected, knowing that if he miss something for which he looked, he will be compensated by something out of range of his hope. One day I was trying to fit a pied bird-form to the loud double chuck of a greater spotted woodpecker in front of me, when happening to look downwards to see where I was going, I saw a swallow sitting in the road, not injured, for presently it got up and flew away, to return and sit down again in the same place. Here was a problem, for the swallow was not dusting. Was it, perhaps, a female and egg-bound, or caught away from the nest by a desire to lay?

Occupied with this queer conduct, I came homewards, passing the swallows swooping down to bathe in the moat and then up again, shaking themselves in the air; watching the swifts tearing and screaming round

1 The following year I heard one in a small copse half a mile from the town. He was a very inferior performer, the poorest I have ever heard. 
the cathedral tower in their evening gambols, and the daws sitting and making love on the shoulders of the saints on the majestic west front, while the young clamoured from somewhere at their backs. So home at dusk from all the wildness and freedom of bird-life about me, to view this scene of domestic bliss, no more inappropriate to the massive dignity of the pile than to my own mood of rest and shelter.

The ducks on the moat were on the borderland between wild and tame, and their actions after pairing were consequently of great interest. They face one another, and rising upon their tails from the water wave their wings in vigorous exultation before settling down again. In performing this rite of consummationfor a ceremony it unquestionably is-their wing-beats keep exact time and measure, and each bird sinks down upon the water at the same moment as the other. Now just as evolution has elaborated the colours of birds and set them in harmonious contrast and gradation against one another, so the movements of birds during the nuptial season tend to become more and more patterned and ritualistic-conventionalized in fact-just as a poem is a conventionalized arrangement of feet and rhymes, a machinery to extract the full honey from the raw material of language. In the raw material of time, when birds were maladroit in the air and dull in plumage, their loves were no doubt a mere scramble of desire, unattended by order and beauty. That these rhythmic designs of movement should survive the degeneracy of semi-domestication is not only an evidence of their tenacity, but of nature's artistic purposes upon her animate creation.

Down the moat, between the old wall embroidered with ivy-leaved toadflax and crowned with the vinouspink, white and purple clusters of comfrey and many other damp-loving plants, the swans would pass in procession with their three cygnets behind them. A water-hen was in charge of three chicks and a duck of eight, and as the pageant advances the water-hen summons her little black folk into the ivy of the bank, and the duck gives an imperative cluck to her yellow 
brood scampering after the flies, and they retire under a branch overhanging the water. The royal tyrants pass on their way, and out come the households of the humbler citizens to pursue the daily round.

In the old elms lining the banks of the moat, in the holes of which blue-tits, wrens and starlings nest, the rooks are putting the finishing touches to their houses on April 1st, and the hens are beginning to sit. Both sexes assist in the furnishing, the cock-bird arriving with a twig, presenting it to the hen, and then jumping eagerly into the nest to help her place it in position. In wet weather the rookery is not half so gay, the birds sitting motionless and silent on the branches, occasionally shaking the rain off their feathers. The daws which mingle with the rooks in the fields never use the rookery elms as perching places unless the rooks are all away, which very rarely happens.

These daws had an evening market-place on the top of a large plane opposite the rookery and on the other side of the moat. Suddenly from fifty to sixty birds detach themselves from the cathedral tower and settle on the plane. There they sit silent for a while, until without apparent reason a storm of emotion rushes through them and they burst into a loud chorus of metallic voices. But sometimes this emotionalism takes a different form. Without being in any way alarmed or disturbed, they all at once leave the tree simultaneously, advance in a solid column over the tops of the rookery elms, stop dead in the air, and, separating into two wings, fly back upon the plane. Then the same thing occurs again, and so may do half a dozen times. The instantaneousness of these cries and movements, the discipline of the short flight and the concerted action seemed inexplicable to me except by the theory of telepathic communication, evolved out of centuries of social intercourse, for I could detect no signs of leadership. A tidal wave of emotion does sweep over them; a call to leave the tree does summon them, not in singles or small parties, but the whole body, and the one is unseen, the other unheard. Another thought-provoking circumstance was that though the birds were then swept 
into a company movement and acted in unanimity and as a corporate body, yet as soon as they returned to the trees, they alighted in couples, each pair close together and separated from the other pairs. The interrelation between the social functions and domestic individualism of the species was in fact presented in dramatic form and as a kind of alternating rhythm. The personal and sexual identity dived, as it were, and then reappeared on the surface.

\section{III}

Between the middle of June and the middle of September practically all the interest of inland birdlife disappears. Fields and groves have no offerings for eye or ear, and the drooping, browning foliage is a sanatorium for avian patients undergoing their seasonal moult. Then suddenly, this anxious period over, they stream gaily and tumultuously out of their leafy shelters, invading the open spaces once more-I had almost said like a carnival throng in Southern Europebut for our impoverishment in brightly plumaged native birds during the last fifty and a hundred years. From then until the beginning of November or later, and all through the winter, if there are prolonged frosts, take place those complicated and internal migratory movements which affect all our resident species. So I returned in autumn to this diminutive city of birds to meet them.

One afternoon, a small colony of half a dozen sandpipers delayed their migration on the moat before passing onwards. Sandpipers are rare enough anywhere in the south; in southern towns they must be nearly legendary. They flew about the moat like miniature mallards, though so much speedier and more versatile upon their sharply pointed wings. Occasionally they would turn like a swallow and expose the pure, conspicuous white of the underparts, uttering all the time in concert their high, clear, musical, triple and quadruple whistle. Their gay visitation was made in the kingfisher's estate, and he, I believe, breeds regularly within five minutes' walk of the market-place, though the young are frequently 


\section{A CITY OF BIRDS}

killed by the swans. I often used to see him speeding straight as an arrow along the middle of the moat, the azure of the back brighter than the fourteenth-century glass I had been looking at in the north transept of the cathedral. Sometimes this Hylas of the moat would perch on a bush over the water with the sun riding on his back, where he would remain quite motionless, a jewelled figure of oriental tapestry, but in the spirit of life dulling the fine colours of the paint-box.

Autumn, indeed, is almost as good a time as spring to potter about this favoured town, escaping for a moment these sombre months and years in the history of man. The saints stand at peace in their arcades along the west front of this most human of cathedrals, and the birds, what with abundance of food, the sorrows of winter and migration ahead, and the toilsome responsibilities of parenthood behind, go about their business in a light-hearted, pleasuring spirit, in which the necessities of life play a smiling part. Their losses are forgotten, nor yet is there any fading in the attentions of lovers to one another, even though the social, the packing instinct begins to drive a wedge into family life.

Wagtails were collecting on the green before the west front, as they were in the cloister-garth, the tombstones of which were perches for the fly-catchers. These wagtails had acclimatized themselves to the atmosphere of the building almost as perfectly as the " ecclesiastical daws." They darted among the gables, turrets, buttresses and parapets of the cathedral, hovering perhaps before some fine tracery of foliage like humming birds above a forest orchid. Then away they would go over a wall or under a cornice with that whirligig, convulsive movement of body and tail, which throws out flashes of black, grey and white. Swallows and martins were assembling in hundreds, keeping more or less separate, the moth-like martins preferring the neighbourhood of the water, the swallows sweeping the lawns and greens an inch from the ground, occasionally disturbing the wagtails (who would take a little skip out of the way) and looking from above like enormous 
purple flies. Then, obeying some secret message (thought transference seems the only explanation), they would rise in a body and scatter all over the irregular contour of the grey stone, like butterflies about the flowers.

It was fine to wander round the buildings grouped into that subtle proportion of line, space and mass which gives the cathedral its supremacy above all others-a supremacy which even the restorer's ugly, thin, bluish shafts adorning the west front like gutter pipes can hardly mar-and watch the wild, giddy flights of the swallows, the daws, the wagtails and the starlings about them. Impressions are both contrasted and harmonious-volume and delicacy, intensity and repose, solemnity and dashing speed side by side, art and nature united in religion.

Art and nature are indeed but parts of the same objective reality; they achieve the same results, they employ the same methods and work to the same glorious end-the survival of the soul, since in the crowded multiplicity of life it alone in all its appearances is the best fitted to survive. Therefore, when I saw a woman in the nave with a pair of tern's wings in her hat, I was right to see in her a blasphemer, and one in spirit with the vandals who cast down the statues in the first tier of the west front. What did she there, with her plunder of the rich genius of God, to display the foulness of mankind in the place of its splendour? Truly, man is the incomparable monarch of the world, both in the height of his greatness and the abyss of his vileness. Nevertheless, the natural historian of animal life-mammal (including man, of course), bird and insect-must tread warily in his judgments. Civilizations have their seasons, their green, brown and yellow leaf, and ours, its labours accomplished, now hangs like a rotten plum on the tree of life. But another civilization overlaps it and will catch up the sifted value of its heritage, and in its turn will give place before another, the civilization perhaps of some humble race unconscious yet of its birthright, until we are brought safely home at last. The word of God, or, as we call it nowadays, evolution, is at the back 
of all life, with its persistent command- "You've got to be good, and you've got to find out what good is," or you shall die. Every living creature answers the call upon it according to its capacities, but we are failing to make our responses to new and higher calls made upon us, and the wages of failure is death. Yet to be cast down at the evil of our times is to lose our sense of horizons, to neglect the circumference for the centre of the circle, and to forget that the surprising thing is not the amount of ill in the world, but of good. We have been barbarians for a year and semi-civilized beings for a day, and God must be given his own time to make his work good. Only he thinks it time we said good-bye to barbarism.

The fascination of the town are its daws and rooks. The former, known as the "Bishop's Jacks," to distinguish them from the "Ebor Jacks," which breed two miles away in the Mendips, are at their best in autumn in the early morning and evening, when the day's business in the fields is over or before them, and the recreations of leisure are in full swing. In the evening they straggle homewards "in scramble sort" with the rooks (with whom they feed), the calm, regular, sonorous bass of the latter contrasted with the ringing staccato and sprightly barking cries of the daws, volleyed crisply from one angle of the stone to another.

Daws are the most boyish, mischievous, impish, happy-go-lucky and mirthful of all the crows. It is pleasant indeed to think of this boyishness in conjunction with the antiquity of the cathedral, and again to think of these daws as older than any cathedral, and the cathedral itself eternally young in art. But the cathedral histories have nothing to say of the daws, as in the descriptions of Bishop Still's black marble tomb they have nothing to say of his black-lettered ditty. ${ }^{1}$ The irreverent sportiveness of the daws, whether they are diving, soaring, floating or tumbling up in their blue pastures or about the great central tower, or sitting clamouring on the heads and shoulders of the holy

1 Actually he did not write it, but that does not exonerate the ecclesiastics, since only of very recent years has it been shown that Still's song has been drawn illicitly from him. 
saints marshalled along the west front, seems to mock everything that is pompous and consequential.

The daws, too, have a special game of their own. A pair of them pursues a third with shrill, metallic cries. The quarry takes refuge in a hole or cranny, and the hunters then perch above it, craning their necks over it, their sorcerers' eyes alive with gleeful cunning. Then the hideling daw cautiously stretches out a neck and suddenly makes a bolt for it, the others scrambling off their perches and taking up the chase again in full cry. They dash into the holes at full speed and with marvellous precision, being suddenly blotted out, as if the grey walls had some magical power of invisibility. Another game is to lay an ambush for one of their fellows and suddenly to dash out at him from behind some corner, pillar or gable. Parties of them, again, often form a solid body and conduct a series of aerial manœuvres and evolutions, flying with great velocity, and obey the telepathic word of command to wheel with a unanimity as mysterious as it is beautiful.

I used to watch the rooks feeding on a large field adjoining the town, and it was interesting to see the social blending with the sexual instinct. There they were stalking or idling or sunning themselves with bodies prone to the ground, wings unfurled and heads and necks outstretched upon the ground. But though the first mists were already throwing grey scarves over the cathedral towers, they were still making love; some of them were actually pairing; some standing shoulder to shoulder with their heads towards one another and mandibles interlocked, kissing in fact; others bowing to their partners with bills buried in the grass, tails expanded and lower parts raised high in the air; others gravely perambulating round and round their mates. It was not so much courtship as somewhat sugary marital bliss.

It is known, of course, that some of our native species pair for life, and a recent essay of Mr. Hudson'sDo Starlings Pair for Life?-adds a highly social species to the number. I think he proves his case, and if he does, he has cracked the hardest nut of scepticism about other species, whose habits are imperfectly known, 
also pairing for life. For starlings are one of the most social of all birds, and if the marital identity is not lost in the immense communal gatherings of winter, it is the more likely to be maintained among species less gregarious. There is no practical reason why the sexual should run counter to the social instinct, and linnets, sheld-drake, rooks (as egrets, weaver-birds, flamingoes, ibises, etc., among foreign birds, not to mention most of the sea-birds) preserve the latter even when the sexual excitement is most intense in spring. It is indeed still more wonderful that the herding instinct should not swamp all closer individual ties rather than vice versa, but I believe that if more evidence were collected on this head, it would be proved what we can only now divine or test in a few species, that many monogamous birds are faithful to their mates and do not forget them even when circumstances separate them for a while (as with chaffinches in some districts and some migrants where the males arrive before the females), or when the sense of community is in full flood. Why not? Why should we assume in our arrogance that love's fidelity is a sole moral privilege of the human genus, and that in the non-human races, genuine, durable love is only a fancy name for the reproductive instinct. It may be that Courthope (Paradise of Birds) was not too far wrong:-

Their bonds never gall,

Though the leaves shoot and fall,

And the seasons roll round in their course,

For their marriage each year

Grows more lovely and dear,

And they know not decrees of Divorce.

But if more birds than we think choose a partner for life, the business of wooing must surely be much more important than we suppose. ${ }^{1}$ Even among polygamous species like ruffs, birds of paradise, etc., the wonderful colours and ornaments acquired through sexual selection could not have been thus evolved if pairing were the

1 See Mr. Julian Huxley's admirable paper in the Proceedings of the Zoological Society upon the courtship of the Great Crested Grebe. It is something very like the wooing and marriage of human couples. 
perfunctory affair many naturalists have supposed it. Elaboration of colouring must be collateral with that of courtship. A fortiori, where species are known to pair for life (viz. the hawks), the preliminaries must call forth a deal more of character, effort, emotion and drama than we are willing to grant or than evidence exists to prove.

\section{IV}

I had many adventures on the outskirts of the town. I would pass half a dozen grey wagtails, sprites of the waterfall, at the east end of the bishop's palace, darting along the bank and leaping into the air to catch flies. The black cravat topping the bright yellow waistcoat had already disappeared, as a lover puts off his airs when his mistress adorns his home and rears his children. There is a steep wood to the east of the town under the wardenship of the "National Trust" (who might with advantage make their notice-boards legible). One day this wood was a forge of chiff-chaffs, hammering on their anvils and bustling out their "Come quick, come quick" to their fellows, to be ready to set off for distant lands. There were perhaps a couple of hundred of them, all the chiff-chaffs of the thousands of trees for miles round. But best of all was a family party of the beautiful black-and-gold-banded siskin, whose rather hoarse, querulous double-note- "why see, why see". (Howard Saunders renders zeisig) -I listened to some time before seeing the birds. Four of them were young, with colours much duller than the parent birds, themselves fallen from the brightness of the nuptial state. I cannot but believe, therefore, that they nested here. Siskins are not shy, but so restless that as they go prancing from tree to tree, making a gymnasium of them like tits, one has much ado to keep up with them. I wonder how many of the worthy citizens of the town are aware that in 1919 a pair of siskins reared their young successfully probably within five minutes' walk of their bishop's palace walls. For siskins breeding in the south are rare, and I believe there are no records 
for Somerset. I can only pray that if they breed in the neighbourhood another year they will escape the collector (not to mention bird-catchers, urchins and local "sportsmen"), that covetous pedant with his glass case for skin or egg, for ever on the prowl.

Now, again, it would be a nuthatch flying out from an oak, tweaking off an acorn, carrying it to a branch, riveting it into some crevice, and then hammer away, swinging the whole body to the blow. The birds were very blithe and active that warm and windless autumn, and one would constantly blunder into a bubbling centre of life in a glade or in some broad pathway in the woods. Then to and fro ran little contented exclamations and broken bursts of song and flying shapes darting across the open space or rustling like wind-blown leaves among the foliage. Suddenly all is still; the breeze of warm and vibrant life dies away.

At one time I was privileged to be a witness at a very curious drama of wild life. A sparrow-hawk was in pursuit of a pied wagtail flying in its erratic way with shrill screams of terror, quite different from the chiz zic of normal happiness. The chase took the birds to a tall elm, and by a clever double back into the foliage, the wagtail evaded the rush of the hawk, who, not being able to turn quickly enough, swung out past the tree. But then, to my astonishment, I saw against the tree the wagtail's mate in close pursuit of the hawk and uttering the familiar cry, not in terror as his or her lover uttered it, but in rage, indignation and defiance. The hawk gave it up and went over the scruff of the hill, still pursued by little David, whose love was hidden in the leaves of the elm. This strange incident was especially interesting to me, for I have observed that swallow and pied wagtail pursue hawks more often than other species, and that the pied wagtail is the most fearless and dashing. I have related other incidents of the same kind elsewhere in this book, but I may say here that I have seen the pied wagtail (sometimes alone, sometimes with his comrades) furiously at the heels of the Philistine as often out of the breeding season as in it. His abrupt and conscious shouts of sibilant 
triumph when he returns from chasing the discomfited kestrel or sparrow-hawk (whom I have never seen attempt to turn on him) are extremely comical-young Jack the Giant Killer sounding his penny whistle.

One day I spent the morning and afternoon exploring the vale of Avalon, that flat, grassy plain, intersected by dykes with rows of pollarded willows and starred and lined with clumps of poplar and elm and hedges of elderberry and thorn. I sat down on the river bank, and a party of five crows came sauntering by, so mentally alert, so deceptively casual, a thing you hardly ever see in the country-only in London. Then out of the misty blue a heron came sweeping and circling round, flying low nearly over my head. No sooner had he passed the elms whither the crows had retired, than out they leaped at him, for all the world as though they had laid an ambush for him. He quickened his flight and rose, but they, beating their wings rapidly and in great excitement, climbed above him and made stoops at him. His royalty was not so much alarmed as disconcerted, and not so much disconcerted as inconvenienced. He gave a load squawk of annoyance, stretched out his neck, made a half-turn and pursued his course with redoubled speed, the crows pelting after him in vain and then giving up the chase. The crows, I am certain, were worrying him out of pure mischief, and looked like urchins of the air beside him. Then, to my surprise, down came the heron into the paddock of a farm, and after walking about under some willows, like a mimsy among the borogroves, settled down comfortably to rest. Some minutes after his mate appeared from the same direction, and the same incident was precisely repeated, half-turn, thrust out neck, harsh, powerful cry, pursuit and all. The second heron caught sight of her mate, and holding her vans rigid, circled about fifty feet above him. He craned out his neck, followed the course of his mate, and then climbed upon his legs and took off after her, being instantly transformed from fantasticalness to grandeur. I was told that being of no "use," the herons of this district are greatly persecuted, and will soon be extirpated unless something is done so save them. 
There were but few birds in the vale-small colonies of linnets and whinchats and occasional commoner species. How this wide land has fallen from its ancient population, when the watcher, looking out over the water into the cobalt blue of the horizon, where the Mendips, mantled in softest lavender, lie like thickened shapes of cloud, would see between him and them thick and glorious squadrons of duck, spoonbill, bittern, harrier, night, squacco, purple, buff-backed and common heron, crane, grebe, swan, ibis, stork, osprey, stilt, godwit, snipe, curlew, egret, and many another, clouding the sky with their multitudes, shaking marsh and mere with their cries, and now passed away for ever, leaving him to fill some few of the empty spaces with falling leaves, like flocks of finches sailing down from the trees to feed.

Back in the town I found a large party of yellow wagtails assembled for migration in a meadow between the High Street and the station. Yet it is an ornithological axiom that they never come about human habitations. They were obliging enough to come within five yards of where I stood watching them, to the mild wonder of the good citizens of the town. Their methods of feeding are very intriguing. Every now and again one of them would cease from desultory picking and grow stiff and point like a spaniel. Then he would make an incredibly rapid, twinkling run for two or three yards, and there was a small, dark object at the tip of his bill. The grace and elasticity of the performance were indescribable, and one could but sigh for those worthy citizens who missed so fairy-like an entertainment at their very doors. The other wagtails go through something of the same action, but it is much less formal and detached.

One day, walking on the grassy uplands, a quarter of a mile from the town (where wheatears still lingered, in spite of the season, and grows the pale lilac, sixstamened, meadow saffron, leafless on its long slender tube), I caught sight of seven thrush-like figures feeding in the grass. They were taking long ungainly hops, then standing stock still and driving the bill down upon the ground in quick succession. It was effective enough 
if it worked out at an ant per stab. Or they would perch vertically on the posts of a barbed-wire fence, half of the body above the posts, half below, and sharply silhouetted against the sky. Or they would take short flights within a few inches of the ground, with never a dip. Tip the body up, and there was your thrush. But that green body, that short stiff tail, that black face, scarlet crown and yellow rump, so joyfully confirming a little theory that the green woodpecker is passing through a transitional stage from a tree to a ground-feeding species, belonged to no thrush. Why should it be more advantageous for the yaffle to become a ground-feeding bird, to be modified structurally no doubt in the far future, ${ }^{1}$ in the struggle for existence? Possibly the answer is that there is less demand for the ants on the ground than the insects he hacks out of the bark of trees, and that competition with other species of his old way of life (barred and greater spotted woodpecker, oxeye, wryneck, nuthatch, creeper, even coletit) is driving him to make a corner in ants on the ground. But I do not feel entirely satisfied with that, for his great bill and long tongue should make him the monarch of the trunk. On the other hand, he has a substantial body to feed. My view is that he has a flair for formic acid.

These are a selection of my theatre-going experiences in and about the town. Nowhere else in the country (except in sanctuaries) have I found birds so numerous and tame, thanks not so much to favourable natural conditions as the kindly, easy-going temperament of the people of Somerset. It is extraordinary how this attitude of tolerance differs from county to county in England (from Cornwall and Norfolk, for instance). It is by no means an active sympathy-we are some way from that, and nobody, of course, dreams of teaching children the meaning and value of the intricate interdependence of

1 The nearly extinct South American Pampas Woodpecker (Colaptes Agricola), which has become a purely ground-feeding and ground-living bird, has been so modified, its legs, according to Azora (quoted by Hudson) being longer than those of other woodpeckers. 


\section{A CITY OF BIRDS}

life. But this toleration-indifference if you like-is free of that ugly utilitarian spirit which views all life in terms of immediate self-interest, and sacrifices use and beauty to its mean ends. And the birds understand this and forgo part of their fears and gladly avail themselves of man's neutrality, until the hope that neutrality will one day become enlightened sympathy is born.

One moony night $I$ walked out to where the tower of the cathedral rose out of the night, its stone diaphanous and dim, like the substance of some rare and scarce earthly thought. I turned up a little close, and heard a party of girls singing in one of a set of minute and beautiful houses that stand arm in arm, facing one another across the paved courtyard. The sweet voices of these happy girls flowed out of the house like a perfume into the embalmed air, where the long chimneys, each of a design different from its neighbour's, cut patterns out of the fabric of space. The cygnets slept. on the moat, a thickening of the diffused and ghostly light, shapes of mother-of-pearl, from which at times rose gestures of expanded wing and curving neck, uplifted and then sinking back upon the water. One were the works of man and nature; interchangeable the separate quantities of sight and sound. The one is multiplicity, and every living thing, when passionately and perfectly itself, is fused into the spirit of all things. It was all music and prayer, and the voices of the singing girls seemed to pass into the religious motions of the cygnets. The world appeared "like the King's daughter, all glorious within"; only fantasy was real, and the silence was crowded with vanished scenes and dead faces. Suddenly there burst upon this breathless calm a torrent of such unholy shrieks that for the moment I grasped the tree under which I stood in terror. There, three yards above my head, was a white owl screaming at me like the damned. There he perched and screamed at me until I shambled off, realizing in sadness that if we are the only creatures who can see within creation, so we are the only ones who live within it at discord with its mighty hymn. For I was banished. 


\section{CHAPTER IV}

\section{GILBERT WHITE AND SELBORNE}

G ILBERT WHITE was born at Selborne-the beneath the "hangars" or hanging beech woods which stretch for many miles across the county, with some few dips into the valleys-on July 18, 1720. Naturalists and men of letters alike have been puzzled to account for his immense popularity. The life of the Rector of Selborne was monastic in its seclusion, and the greater part of it was spent in his native village in tranquil observation of "the works of God in the creation," with occasional excursions into Lincolnshire, Ringmer by the Sussex Downs, Switzerland, Rutlandshire, and eighty miles afield to fetch home his tortoise, Timothy. He died in 1793, having accomplished nothing in his life but a series of letters to his naturalist friends, Daines Barrington and Thomas Pennant, which were published in quarto, apparently upon their persuasion, in 1789, and dealt with the natural history of his parish, particularly its birds, with some account of parochial antiquities of no value whatever, and perhaps only written as a concession to the Gothic play-acting of the age. Yet this shy, unpretentious little book, businesslike, strictly limited to the subjectmatter, utterly free from flourishes, intellectualisms and philosophic speculation, and as quiet as a windless midsummer night, is not only cherished and venerated by the naturalist, who turns a blind eye to its obsolete errors, and the man of letters, who turns his to its natural history, but is really the source of an illustrious phylum. It flowed through Edward Jesse of the Gleanings (who published a portion of White's MSS.) and his like, and forked into two branches about the middle of last century, 
the one moving towards modern "humanitarianism," the other to the admirably precise field natural history, which, almost overthrown by laboratory and museum specialization, shows signs of emerging the stronger and more useful science-not to mention its graciousness.

What, then, was White's achievement? First of all, one is inclined to think, a triumph over the eighteenth century. In style, manner and attitude White was eighteenth century to the bone-the best of it in maturity, elegance, fastidiousness and easy, cultured grace. He was " an admirer of prospects," and church spires he regarded "as very necessary ingredients in an elegant landscape.". Of a gentleman much taken with echoes:-

From a seat at the centrum phonicum, he and his friends might amuse themselves sometimes of an evening with the prattle of this loquacious nymph, of whose complacency and decent reserve more may be said than can with truth of every individual of her sex.

There is nothing amphibian here : the perfect urbanity of White's rusticity would have passed the most exacting coffee-house standards. But when it comes to his method, he is as much a stranger to his age as Blake was, whom he could as little have understood as the polite circles of metropolitan culture could have understood him riding forty miles to see a heronry, or creeping about on hands and knees, revealing the domestic secrets of the field cricket. Precision of statement, exactness of knowledge and observation, an absorbed interest and curiosity for the problems of natural life hitherto untouched (Willughby's Ornithology is more a legacy of the bestiaries than a prophecy of White)-this was bucolic savagery to the eighteenth century, which could be discreetly rhapsodical about the nymphs of fancy who lived in trees, but turned up its poetic nose when the nymph of fancy was metamorphosed into the nuthatch of reality. It cannot be too often insisted that the eighteenth century abhorred facts and particularities : that it had a passion for the vague, the abstract and the remote, which ultimately destroyed all its 
standards and fashions, and made its toy Gothicism a perfectly natural development of its decline. In spite of its conformable style, it would have ostracized the Natural History of Selborne, because its facts about real things were an offence against good taste-had the work ever come within its radius of judgment. Thus, White accomplished something very notable when, as I say, he married urbanity to rusticity, the fine gentleman to the dairymaid, a style like the "placid and easy flight" of migrating swallows with the "life and conversation" of the swallow himself.

White's actual discoveries in natural history have been so enormously extended and sometimes displaced by Darwinism and all its later consequents and perfections that there is a tendency to belittle them. We think of him as an author who contributed to our pleasure rather than our knowledge. That is an injustice. Nor is it only in the famous passage about earthwormsthat "half the birds and some quadrupeds are almost entirely supported by them," that they are the great promoters of vegetation by boring, perforating and loosening the soil and "rendering it pervious to rains and the fibres of plants," that worm-casts are the finest manure, and so on, and that the earth without them would become "cold, hard-bound and void of fermentation, and consequently sterile" -that we can read prophecy and anticipation of the overpowering revolution in men's thoughts about the world in the middle of the nineteenth century, whose only analogy in evolutionary significance is the discovery of metals. "A circumstance respecting these ponds," he says in another passage but rarely quoted,

though by no means peculiar to them, I cannot pass over in silence; and that is, that instinct by which, in summer, all the kine, whether oxen, cows, calves or heifers, retire constantly to the water during its hotter hours; where, being more exempt from flies, and inhaling the coolness of that element, some belly deep, and some only to mid-leg, they ruminate and solace themselves from about ten in the morning till four in the afternoon, and then return to their feeding. During this great proportion of the day they drop much dung, in which insects nestle, and so supply food for the fish, which would be poorly subsisted but for 
this contingency. Thus Nature, who is a great economist, converts the recreation of one animal to the support of another !

Undoubtedly, this is reading the lines of the "correlation of organisms," a vast system of interlinkages which Darwin himself hardly probed to its full facts or philosophy, but which, all the same, is the most important enlightenment of Darwinism both for the future of the human race and a right understanding of the universe. White, too, knew something about adaptations (when he describes the perfect suitability of the organs of the Great Northern Diver to its needs); he dimly realized that "hunger and love" were the two great motive and mobile forces of nature's system; he understood that birds do not increase in spite of their prolificacy (if he had gone a step further and asked himself why, he might have strode a hundred years); he declared that "there is a wonderful spirit of sociality in the brute creation," which is a throw-forward to Kropotkin's Mutual Aid; and there are other examples.

Nor is it true to say that White's vision of the natural world, as on the whole a kind and smiling abode for happy beings, was a virtue of temperament rather than a reflection of knowledge. Knowledge is useless and a curse to mankind and all life unless it be rightly interpreted, and because we have put the accent on the wrong word-on the "struggle" rather than the "existence," and again on Malthusian rather than actual Nature-we have no right whatever to blame White because he put his accent on the "existence," knowing very little of whence it came and whither it goes. The theory of incarnadined Nature's predacity, mercilessness and predominance of brutal force, has done uncountable havoc and mischief in the world by presenting man with a moral certificate for his own rapacious exploitations; and if White regarded the face of natural life with a delight and love which lit it up and seemed to him to emanate from it, it may be that our further knowledge will (as it is already beginning to) corroborate what he divined and saw rather than knew. If he knew little of the origin and growth of natural life, 
he understood it for what it was, a time, however brief, of energy, happiness, change and experiment, a time of effort and adventure, in which social life and parental love play an increasing and expanding part in its progressive struggle.

The Natural History of Selborne is an inquiry into the "life and conversation of animals," and it would be a mistake to treat it as something different from itself-a record of field observations. There is little that is old-fashioned here, and the errors are a guarantee of the soundness and perspicuity of White's judgment. He never discovered that the swift is not a congener of the "hirundines"; he never distinguished between the tree and meadow pipit; he confused the call notes of the great with the marsh tit, and he was strangely unaware of the existence of the cirl bunting, though it sings to this day in the little churchyard where he lies buried. He knew the sedge-that "delicate polyglot"-but not the reed warbler; the yellow wagtail and the whinchat, but not that they were migrants; and he is sorely tempted by the theory that martins and swallows pass the winter in crannies and holes and at the bottoms of ponds, a wildness of hypothesis he would not have entertained for a moment had he possessed an A B C knowledge of anatomy. And White was quite right to be puzzled about the sudden appearances of a few swallows and martins on a warm winter's day.

But these nuga antiquae are a featherweight against his enrichment of natural history. In bulk his letters are indeed extraordinarily free of blunders and howlers, and British zoology owes a great deal more to him than the discovery of the harvest mouse, as English literature owes a great deal more to him than an initiation into the mastery of letter-writing. $\mathrm{He}$ wrote charming and faithful sketches of caprimulgus; he found out that the sexes of chaffinches separate in the winter; he was the first to distinguish woodwren, willow-wren and chiff-chaff, and other fine things too numerous to mention. Natural knowledge practically begins with Gilbert White, just as he is the 
first writer to convey it by means of a persuasive literary form. This latter he owes as much to the accident of historical origin as to his genius, since the age of specialization, with its exclusive priesthood and oracles of jargon, had not yet possessed the field. The admirable little monographs he wrote on his darling "hirundines" are models both of accurate observation and precise language, and the literary man, the naturalist and the humanitarian might well join hands over his grave in homage to the ancestor of their common understanding, purposes and interests. The man who was "touched with a secret delight" to "observe with how much ardour and punctuality these poor little birds (swallows) obeyed the strong impulse towards migration" was a lover who acquired knowledge by the spur of his affections, who grew more fond by the increasing of his knowledge, and who fused his love and his knowledge by the power and subtlety of an appropriate artistic method.

White found out these secrets of life and expression by a kind of natural force and amiability of personality which give distinction, weight, and discernment to his observations and an unforced balance and liveliness of movement to his polished style. To put a writer's lastingness down to his personality is rather begging the question, but in a peculiar way White's book is all the man and the whole man. No writer is less self-conscious and individualist, or more objective in the sense that his whole mind, heart and skill were devoted to revealing something quite outside himself. He seems to have had very little idea of his epistolary virtues, and in one letter to Pennant he writes with naïve charm :

On a retrospect, I observe that my long letter carries with it a quaint and magisterial air that is very sententious, but ... I hope you will pardon the didactic manner for the sake of the information it may happen to contain.

There was about as much self-importance in White as there was light-headedness in Timothy, his tortoise, and he is a standing example of the truth of the 


\section{4}

\section{BIRDS OF THE COUNTRYSIDE}

artistic axiom that he who shall lose his personality shall save it. Mr. W. H. Hudson, on paying a visit to Selborne, was reminded in a very beautiful piece of imaginative writing of Nicholas Culpepper's line-" His image stampèd is on every grass"-and when I went to Selborne myself, before reading Mr. Hudson's account, I did feel his presence with extraordinary, almost physical, vividness. There is at any rate no doubt that "his image stampèd" is on every line of his work, limited as it is in scope and prosaic in temper, and the accomplishment of a man who hardly ever left the boundaries of his own sequestered parish. White, with his grave, courteous manner, and in his lucid, composed idiom, told us all about a certain place, but that is by no means a corollary of the artistic genius of place. This is an immaterial thing, a spiritual endowment, and one feels it by an awareness of his presence in the shadows of the old churchyard yew as behind his workaday language. It is surely one of the wonders of art, embracing man and nature, the living and the dead, that the correspondence of this country stay-at-home should have made that parish a mental rambling haunt for the whole of the English reading world, and more abiding and famous in story than a hundred battle-fields. But perhaps the most permanent impression we receive from reading White is not the place he lived in nor the history nor the art, but the man. Art and natural history both take their truth of being from character, and here is a whole, real, simple man, born two hundred years ago, and as actual and genuine a human person to us who live after him, as he was to his parishioners. This is the immortality of art, which embraces man and nature, the living and the dead.

\section{After Gilbert White-Selborne, and I shall here give} an account of one of my visits there. If a man, be he ornithologist or lover, wishes to get the hang both of Gilbert White and Selborne, let him read Mr. W. H. Hudson's account of his first visit to this remote 
Hampshire village. Mr. Hudson sat under that famous, patriarchal yew in the churchyard, and there, not the ghost, but a kind of earthly emanation, a "residuum of life," a faint surviving image of the man, appeared to him. The two conversed and compared notes, the eighteenth century questioning, the twentieth responding. And this duet is a piece of really inspired prose, by which we are made to comprehend how far we have advanced from the eighteenth century to the modern attitude to nature. Nor, in a few lines, could the personality of the gentle, domestic, old scholar of nature be more magically summoned out of the past.

This, then, was the message of Selborne, and made the walk to it something of a quest, almost an initiation, as though, hidden beneath some grass-blade or in the ivy of the church tower, there was to be found a minute "crock of gold."

When, therefore, I set out for Selborne over the high table-land from Petersfield through Froxfield and East Tisted, I felt I was doing the best I could for the emotional promise of the day by keeping an attentive eye for the birds in my neighbourhood and an attentive inward ear for that refined and spiritualized conversation, like the vivid though leisurely intonations of two blackbirds.

I had not gone far when I heard a willow-wren murmuring from the bough of a hornbeam by the side of the road. It was one of the first I had heard that spring, for though the willow-wren is one of the earliest migrants hither, it takes longer to get into its musical stride than do chiff-chaff, blackcap, wood-wren or gardenwarbler. Warde Fowler has given a very exact description of the bird's "dying fall"; Burroughs, the much overpraised American ornithologist, who paid our warblers a visit, speaks of its "long, tender, delicious warble-the song of the chaffinch refined and idealized". (I cannot myself see the faintest resemblance in it to the chaffinch's song), and Mr. Hudson of the likeness of the notes in the finished cadence to the human voice, and so appeal to human sympathy. It is not at all 
an elaborate or brilliant song, and the languishing notes, though they do not always float down to the last sighing diminuendo, are always repeated in the same order. Yet it is a song to which I could listen longer than to that of any other small bird (except the nightingale) I know, so fragile is it, but so lingering that after some minutes it steals into and interpenetrates the whole being, until one breathes and moves by music, as though personal identity were relaxing and shifting, swinging into the measured beats of nature's pulse, caught up into that great pendulum of song that surges up through drone of gnat's wing to the chiming of the star, and now down, a shaft of light, a loosed wind, a leaf, down into the fainting Amen of this yellowish-green bird-form among the green-winged branches.

There is, indeed, a double appeal in the willowwarbler's song, the one belonging to the natural festival of renewal, the other to human sentiment-a good morning and a good evening. It is the music of the wind-flower, clear, yet low, and is the very expression of shy, maidenly, early spring, when the April morning is like one of Blake's children and the shy-peering grass, the primroses and bluebells seem rather dimples than shapes, rather melodies than colours, each with its separate note, but blended all into one concert of praise. But while aerial, the song is also human, not in the tone, I think (as Mr. Hudson says), but its expression and the gentle stimulus it gives to associations of the past. It is too subtle for melancholy, and its plaintiveness is free of sorrow-it voices, shall we say, what old Lyly would call " a pleasing pain." Though it is impossible for the human ear to distinguish by any difference of note or quality between a bird's song uttered in anger or anxiety and one of rapture, yet intoxication of spirits, the overmastering gladness which is in all nature, are what commonly impel a bird to sing, and of such is the willow-wren's elegy. But for us an elegy it remains, a reminder and looking backwards through the screen of leafy memory drawn aside by it. Thus the song I heard was a true dispensation for my journey to Selborne, and I could go ahead, boldly 
paraphrasing-" a day of memories and sighs I consecrate to thee."

I was glad to find the yellow-hammer common along the hedgerows, for they are favourites of mine, and I wasted a good deal of time watching them singing their little hymns, like a sighing gust of wind among tall grasses, beaks comically lifted to heaven and golden heads shining in the sun.

It is a thing to note that the chaffinch, greenfinch and this canary of ours are the only native species who run up a flourish at the end of their set song. The yellowhammer's phrase is, of course, a much more humdrum affair than the chaffinch's : he does not put himself out about rivals, and song to this comfortable body sitting on the top of the hedge is what a pull of his pipe is to the placid countryman perched on the top bar of a gate. I doubt whether he prefers wild and incult lands so much as is supposed. No, he likes to take his ease on more cultivated uplands, upon the lower branch of a tree or the summit of a thick hedge intersecting wide fields, where he can get a good view and sibilate away to himself all the warm, long day. I imagine he does not think much. It is an amiable musing, and his reverie goes ambling over the different objects that present themselves like a humble-bee from flower to flower. Yellow-hammers fight, of course, in the breeding season with as much fury and as little damage as other birds, but I maintain that they are the most absent-minded of all singing birds.

Here, too, turtle doves had settled for the summer, and their low, tremulous croodling or purring notes accompanied me for a couple of miles. They have a beautiful love-flight, sailing down to earth, with arched wings and expanded white-barred tails, in a slanting glide, that makes the curves of Milo's Venus look mean, and finishing up with a crack of the wings, like the woodpigeon's. There were several pairs of lapwings building in the fields, and I once turned aside to try and find a nest, ${ }^{1}$ not because I cared much whether I

1 The perfect adaptation of the colouring of the egg to its environment makes it a very difficult nest to find. And I think 
found it or not, but simply for the pleasure of having their company in a world where the larger birds shun our presence, as Coleridge's walker fled the "fearful fiend, That close behind him treads." So I walked about, enjoying the unique sensation of these fine birds following me all over the field, flying close round my head, and displaying the utmost anxiety and fearlessness. But at last I grew ashamed of getting my pleasure at the expense of an emotion painful to them, and slunk off, being seen safely and some distance off the premises by the outraged tenants. They are wily enough when the hunt is a determined one, and I knew when I first peeped through at the sentinel male he would signal to his mate to run from her eggs or chicks before rising from another quarter of the field to join him in a protest demonstration, half-politic, half-earnest. The cries of lapwings are much more varied and musical when the sexual impulse is at flood tide than at any other time, and though they will "tumble" out of an excess of high spirits in autumn as well as spring, they will pirouette and dance and sport irregularly in the air during the nuptial season as at no other time, as though the exhilaration of living demanded a kind of free verse movement in flight.

So I jogged along that lavish, swelling, varied, though never grand country, finding both whitethroats, the lesser just as demonstrative and excitable as his cousin, and singing his shrill, garrulous warble with crest raised, body shaken, and throat puffed out and vibrating in the fine frenzy of melody. The common whitethroat's song is also an ejaculation, sharply grated out, but it is more varied and less brief, and its scolding notes are interchanged with others of a more musical quality. Both these little warblers are twigthumping orators. The lesser is more arboreal than the common, and prefers the tree-tops. I heard an occasional blackcap and garden-warbler, and saw two or three jays and magpies, before I arrived at the long, winding street of Selborne village.

that the reason partly is that the bird deliberately selects a spot most resembling the colouration of the egg. 
The first thing I did was to climb the "zig-zag"(constructed in White's time) of Selborne Hangar, to wander on the common. Birds (except wood-wrens) do not frequent the beech which White called "the most lovely of all forest trees, whether we consider its smooth rind or bark, its glossy foliage, or graceful pendulous boughs," for the simple reason that its woods permit no undergrowth, and nowadays there are no honey-buzzards (as there were in 1780) to build upon the canopy of foliage. But there were none on the common, a wild, desolate, and untamed land, commanding many a fine prospect of the irregular, rolling, fecund Hampshire country, though I found a throstle's nest, and that went some way towards compensating me. How wonderfully beautiful the eggs are in their natural home-blue oval skies, powdered at the poles with black stars and with a greenish tinge over the blue, as if the earth had stained the heavens! In the collector's cabinet they look and are no more than pebbles or coloured marbles. When I find a throstle's nest I am often reminded of John Clare's sonnet, "The Thrush's Nest":-

I watched her secret toil from day to day-

How true she warped the moss, to find a nest, And modelled it within with wood and clay; And by and by like heath-bells gilt with dew,

There lay her shining eggs, as bright as flowers,

Ink-spotted over shells of greeny blue.

And there I witnessed in the sunny hours,

A brood of Nature's minstrels chirp and fly,

Glad as the sunshine and the laughing sky.

Clare ${ }^{1}$ has none of Barnes's fastidiously and exquisitely learned secrets of melody. But they are alike not only in being both good, precise naturalists, but in clothing their verse in a certain lovingkindness. It is not fantastic to tie their qualities up together. The absorbed watchfulness of these poets upon the beauty of the visible

1 Clare's spirit (and above all things he was a lover, a poet of the spirit), with its keen particularity, survives not only by its own virtue but in the poetry of a modern, E. C. Blunden. 
world-about the invisible they bothered themselves little-seemed to transfer the beauty not only to their numbers, but their personalities.

So I left the waste and set off down the pretty village street for the Plestor, the little square with the sycamore which has supplanted "the vast oak, the delight of young and old," overturned by a tempest in 1703. Thence into the churchyard, keeping the eyes resolutely turned away from "The Wakes," which now looks like my suburban residence in London. Happily, there still remain the churchyard and the massygirthed yew and the cypresses and the squat, square tower of the church, which no rich man has yet thrown down to rear a mighty fane to his Sovereign God. Still, too, hovers the blessed spirit of the place which hides the small leaning gravestone of Gilbert White with long, waving grasses. That stone, with "G.W." upon it and the dates of his birth and death, is still inviolate, and no progressive person has stood over it and exclaimed: "What needs my Gilbert for his honoured bones?"-while the affrighted familiars of the spirit shrieked and departed. But all the screams I heard were the modulated ones of the greenfinches, varied with their fluttering song. The greenfinch, indeed, the olive bird with a slash of gold flaming above the flank when the wings are closed, was the commonest bird in the churchyard, and his lively ripple (greenfinches are great talkers) went breaking over the boughs swaying in the breeze. In the big sycamore, where, Mr. Hudson tells us, he saw the cirl bunting (I saw him on the way home), a daw was building, and the hole was so small that the female took half a minute to squeeze herself through. Lower down on the same tree a fly-catcher had its perch, and repeatedly swung off it to round up a fly in a sweeping curve and return. In White's time twelve pairs of swifts circled the tower in their evening revels. When Mr. Hudson went to Selborne it was eight, and I saw but two, though this year (1919) swifts outnumbered both swallows and house-martins put together. It made me uncomfortable to think what White would feel about our dwindling 
" hirundines," dwindling so surely year by year, now that the French, Spaniards, and Italians have found a new and improved method of taking them on migration, so that the security and quietude of that old churchyard seemed menaced and ruffled, and I left it.

I went home by the Liss main road. Every halfminute or so motor-cars passed by in a convulsion of stinks, dust, whirr and hoots. In the middle of the road, perfectly quiet and composed, stood a little bird, uttering every few seconds a subdued, pensive, sorrowful twitter. Whenever a motor squealed by it fluttered under the very wheels into a near holly-bush, and when the clamour had subsided flew down again into the same place, uttering that plaintive call. I was astounded when I recognized the shy goldfinch. So I walked up to where it stood (it was a male), and there I found the body of another goldfinch-not a body, but a shell, all that was left being the outer skin clothed in faded feathers. It had been dead several days. I took the bird and laid it in some long grass by the roadside, and as soon as I had turned my back, the live bird flew down from the holly and perched beside the grass, uttêring his mournful, scarce audible requiem. Then at last did I understand that strange talk between the two naturalists in Selborne churchyard, now that nature had shown me this wonder, now that I had found the crock of gold. 


\section{CHAPTER V \\ BIRD-HAUNTED LONDON}

I

THE title of this chapter is a misnomer. My 1 observations of London birds are confined almost exclusively to the district in which I live-an inner, south-western suburb near the river, and in brave, legendary days a fourpenny bus ride from Charing Cross. It is true that I have penetrated our brick jungles in search of wild bird-life in various parks and open spaces. But the changes commented upon by Mr. Hudson (who gives a list of forty-nine breeding species in Kew Gardens in Birds in London) are now accomplished. It is a great mistake to suppose that the parks belong to the public, and it is not they who are to blame for the banishment of the wild birds, but the singular passion of park authorities for parlour-maid nature. They are born into the world with a mission to turn Tib, Marian and Silvia into Chloris, Celia and Sacharissa, and they spend their lives in making them presentable. Tib's hair is apt to steal down upon her eyebrows, Marian laughs like a mad thing, and Silvia's green girdle is all frayed at the edges. Back with it, down with it, away with it! So for years these worthies have been lopping boughs, trimming grass, uprooting undergrowth, until at last they have succeeded in tidying up the tousled nymph for the drawing-room, and have manicured nature down to the quick of their own tidy little souls. Unless used for agricultural purposes, the open spaces in and about London are now like sets of eighteenth-century heroic couplets. But the birds do not share their tastes.

Kew Gardens are intended to be little more than an 
open-air botanical museum. But even there Nature might be allowed more freedom to stretch her limbs and unbind her hair. But I have a soft place for Kew, chiefly because of a human memory, and partly because I once saw a party of goldcrests there in a larch grove (they nest in the Gardens), and a place where goldcrests live lays a spell on me. One early October morning among the pines of a Suffolk heath, their branches draped and festooned with gossamer, clustered with dewdrops, like mantillas on dark hair, I met a large company of goldcrests breaking over the trees under which I stood in a wave of greenish foam. Bright drops of shrill sound-zee, zee, zeefell from them in showers and, crystallized in the sharp air, entangled themselves, it seemed, among the gossamer. The delicacy of that happy sight give places haunted by goldcrests a particular grace of association for me.

Richmond Park is slowly recovering from Sir Alfred Mond. It is visited by many of the migrants, but the sparseness of the undergrowth prevents most species, except those building in holes in trees, from making a home of it. Jackdaws, rooks, woodpeckers, mistle-thrushes, owls, jays, nuthatches, creepers, tits and starlings frequent it in some numbers, and the heronry in Sidmouth Wood is a wonderful sight in early spring. Visit it in March and the birds will be seen floating among the trees, alighting awkwardly among the branches and standing, gaunt and statuesque, on the platforms of the bulky nests. There are occasional tiffs when a bird trespasses upon the legitimate tree of a nesting pair, and many love-scenes, the couples caressing each others' necks and bowing long bills with the most flattering air. The scene, indeed, is like that of an older world, and it would be no great feat of illusion to transport oneself back to a nesting colony of Pterodactyls. The birds are very noisy in the breeding season, and their cries are more mammalian than bird-like, the only bird-sounds they resemble being the honking of geese, the quacking of ducks, and the guttural calls of coots and water- 
hens. One approaches the heronry as to a menagerie, resounding with grunting, squealing and barking notes like those of seals.

The great crested grebe resides on Penn Ponds among the coots and mallards, though $I$ have never seen more than three pairs. There I have seen their wonderful nuptial dances on the water, the shining breasts conspicuous a quarter of a mile away. Nuthatches and greater spotted woodpeckers are not so uncommon in the groves of old oaks as one would suppose. In March I have heard the greater spotted woodpecker drumming his love-song on the bark of an oak. It is a rapid tattoo, a loud imperative summons, and the bird (showing great excitement) takes pleasure in varying the pauses of this instrumental music, the blows being repeated in succession from half a dozen to a score of times. The most extraordinary thing I ever saw in Richmond Park (on October 25, 1920) was a hooded crow. I would have rejected my identification in favour of an aberrant carrion crow but for the fact that $I$ saw the bird at close quarters and for two minutes' length of time. Nobody, of course, will believe me.

Wimbledon (I am told the kingfisher haunts the Wandle, but I have never seen it there) and parks in other districts of London I know too little to give an adequate account of their birds, but ' $I$ will make a brief reference to a visit I paid to St. James's Park in the June of 1919. The Government dragon had spewed out its rubble over the greater part of the charming lake-once a mistress "sweet and kind". to water-birds-and had built itself a squat den on top of it. Obviously this outrage was too much for the dabchick, which nests there no longer. The lake now is little bigger than the average heath-pond. The less specialized water-hen, however, had stuck to its quarters and conducted its young about among the pelicans and ornamental water-fowl-the only authentic wild bird of them all. The pelicans were ludicrously disproportioned to their surroundings, looking like eccentric angels on exhibition. Nature has 
made them comical and dignified, grotesque and superbly beautiful simultaneously, but here the scales were tipped the wrong way. None the less, they were comparatively happy and not gaoled in the Zoo, whatever their limitations.

But my intention is to confine myself to my own locality, and it may not be altogether a work of supererogation to describe what I have seen with my own eyes in a district only mentioned in passing by previous writers, so accessible from the centre of London, and at dates so recent as 1918, 1919, and 1920.

\section{II}

The peculiarity of London wild bird-life is to be almost entirely nomad and seasonal. With the exception of sparrow, titmouse, owl, crow and heron, I do not know of a single species which remains in the same place throughout the year. All is shifting and unstable, and the same bird that stays to-day, tomorrow will be going. Unless, therefore, one is dealing exhaustively with the bird-life of all London as Mr. Hudson did years ago, it will be convenient to take it by rotation of the seasons and to begin with the autumn. When the last of the summer migrants have departed, the mighty wave of winged life still surges from north to south, scattering in its passage a few flecks of foam upon the mirk miles of London Town. The country round my home is open, flat as a planed board and treeless, except for the orchards, one on either side of the river, a few scattered sycamores, poplars, and elms, and lines of elms and willows along the banks, a highway of migration. Most of the land, with the fertility of the rich alluvial deposits of the river to encourage it, is highly cultivated with vegetable produce, and there is something harmonious and restful to the eye in the long symmetrical rows of green shoots channelling the dark earth. I can never fall out with a long line, be it but that of the provincial cabbage. For that reason, I grew to dislike the little allotment patches the more I saw of them. Their 
pinched confusion of outline at once destroys the large rhythm and repose of the fields, and I do not think it fanciful to see in their ugliness a wrong and brusque method of relationship with the earth, a kind of ungraciousness with it, in which the poverty of appearance naturally and in the long run corresponds with that of material results. It is wonderful what a lot of practical work real beauty manages to do.

Except for the gulls, who seem to come up the river earlier every year, ${ }^{1}$ there is very little bird-life along the river until the winter. The land is the enclusive stage for exits and entrances, and the woodpigeon, who leaves us in September (sometimes in large flocks for the country, death and richer food, the survivors trickling back to safety in December and January like a routed army), gives the signal for the procession to begin. I once saw a detachment in early October thus migrating in a high wind, and as they wheeled, taking a corner of the gale, they threw up their wings into a beautiful arch in the manner of redshank and ringed plover. Then I saw no more of the ring-dove until the end of the first week in December.

The land now begins to serve as a collecting station for autumn flocks, like a miscellany of poems. Some days after the wood-pigeons had gone I blundered (on a day of yellow fog) into a migration of blackbirds. They had stopped to rest in the may and elderberry hedged orchard on my (the Surrey) side of the river, and I saw as many as thirty of them in the gloom, while the clogged air vibrated with metallic detonations from at least thirty more black knights-errant hidden among the trees. Next day two-thirds of them had vanished, and gradually the party thinned away into the unknown, until in another week only the original residents-half a dozen or so in number-who remain with us until the nesting season (most of them being eaten by the "rakehelly rabblement" of cats) were left. Yet with

1 The earliest I have seen them (a pair) was on August 4th -perhaps a pair that failed to rear a family. 


\section{BIRD-HAUNTED LONDON}

the running out of one tide of life, another sets in, and larks, lapwings, pipitss, chaffinches, greenfinches, dunnocks, mistle-thrushes and pied wagtails begin slowly to dribble in upon us like people going to church. One day I actually saw a bullfinch disappearing over the hedge into the orchard with a gleam of his white rump. I had but time to shelter him in a grassy recess of memory, for that was the first and last $I$ have ever seen of his loved kind in or near London. Once, too, I saw a corn-bunting feeding in a cabbage field among sparrows, chaffinches, gulls and lapwings.

Lapwings lend a peculiar distinction to my neighbourhood, and by the middle of December, when they muster on the banks of the river and still earlier in cold weather, they are more than a hundred strong. They are as often in pairs as flocks, and it is possible that Mr. Hudson's account of the starlings preserving their marital identity in the winter congregation also applies to the lapwing. Courtship begins as early as the middle of a mild February, the male advancing towards his fair with dancing steps and uplifted, quivering wings.

One autumn day I received a striking demonstration of the probability of the starling theory. I disturbed a band of starlings and sparrows congregated on a tree under which I was passing, and a starling, having collided with a sparrow, was furiously pursued by it and separated from the flock. No sooner were the pair of them fifty yards or so away (they travelled at right angles to it) than another starling detached itself from its fellows, flew after and joined its partner.

The immobility of the lapwing serves it wonderfully as a protective device on a ploughed field. I was once sweeping such a field with the glass on the Middlesex side of the river, when the wings of a lapwing were raised, and I suddenly' perceived that the field was full of them. So perfectly did the metallic greens of the back match the subdued high lights of the clods that the birds had baffled even the searching cunning of a field-glass. Without the glass I could not see a single one, though it was 
a clear day, the birds within fifty yards of me, and I knew them to be there! In rest, they are indeed as still as bird statues, standing with hunched shoulders and necks drawn in, like bronze green flowers in a windless land. This is plain evidence that "protective" colouring even in our land need not be and is not always dull. A golden oriole in the chequered sunlight of the trees would be protectively coloured.

What a contrast is the lapwings' quietude with their flight, the flight of a miniature heron with none of the steadiness! They are like large leaves casually whirled about in the air, and they seem to delight in showing off the blacks and whites of their wings as irregularly and yet rhythmically as a dancer displaying her limbs. In spite of their rounded wings, they take the wind with more ease than gulls, the reason possibly being because, like many other of the Charadriida, they make use of body action in the air. It may be this superiority that makes gulls sometimes stoop at a lapwing flying among them. They enjoy taking the air of a moonlight night, and one November I was out in the fields at half-past eleven listening to their ghostly cries and watching their wavering flight round my head in a light itself ghostly and wavering between dusk and dawn.

In late summer and during the autumn herons used punctually to fly over my house from the Richmond heronry in the morning and back again in the evening, and it is not until the winter that one or two of them are to be seen stalking along the river-bank. I have seen twelve, thirteen, sixteen and nineteen herons, doubtless parent birds and young, marching the air from my window. One heron, with its Marlowesque flight, its unhurrying stateliness and power, is sufficient to banish common thoughts. But nineteen, thrown out into a wide, irregular mass and cruising a stormy sky into the rich turmoil of sunset-here is the grand style.

Birds are good barometers, and it is curious to see how the autumnal swelling of their numbers is affected by weather conditions. The process is only cumulative 
if the weather keeps open and humid, but let a cold snap occur and the numbers of the starlings are dwindled, some of them no doubt going overseas without more ado, while other species spring into notice like mushrooms. I have been out one day and seen a meagre sprinkling of wagtails, larks, greenfinches, chaffinches and pipits, and gone out three or four days later with winter snatching autumn roughly to his embrace, to find ten and twenties for pairs. Autumn repulses her Esau, and the birds are back in their original numbers. By December the larks are assembled in thirties and forties, and the pipits running and fluttering over the weedy patches. Should a frost dig its nails in hard, they will make for the river and pick about among the stones and mud like their cousins, the rock-pipits on the seashore. ${ }^{1}$ Dun. nocks prefer holding on to the allotments and the apology for a hedge round the orchard, and even adventuring among the virgin forests of artichoke in default of more congenial surroundings. I become more and more convinced of the elasticity of birdlife and readiness to change its habits when occasion demands. Among the higher animals, instinct, uncoupled by a vigilant intelligence, would poorly serve the needs of daily life. I once was present at an upheaval in the mild dunnock world, when half a dozen of them assembled to shoo a cat away in a chorus of alarm-cries. The cat yielded the field to the reinforcement of my little red dog, and one of the vicarious victors at once burst into song, less in triumph than relief, albeit a savage east wind was sweeping the plain.

Apart from the skylarks, the kindest sight among the small birds hereabouts are the greenfinches and wagtails. Now and again I have seen as many as thirty of the former in a single flock, undulating through the air and uttering their glad, inflected

1 The pipits pair as early as February, though they do not remain to nest; and the larks, if the weather is not too severe, disband about the middle of the same month. "Internal rhythms" respond to "external periodicities." 
twitter like a wavelet or a vibration of ether or the birds' own flight; or ercet on the tops of bushes and pea and artichoke stalks, little shining green knights with golden swords strapped to their thighs. Wagtails are quite numerous, and so my walks over the same ground were always insured against dullness. They trod the dark ploughland with their mincing steps, tossing their heads backwards and forwards like Indian balancers, or took erratic wing to alight again with a sudden switching off of the current of flight, turning right about face. Here, too, they cultivated the charming habit of perching and swaying on the tips of the cabbage leaves. Wherever men worked in the fields, these Robin Goodfellows came dancing down to them, and to see birds in close touch with men, each benefiting the other, is to me ever beautiful and moving. I never saw them other than in pairs, and often toying and sporting with their mates, even in frosty weather. If the pairing instinct thus survives the pairing season, as I have observed with numerous species, it must be something more than a pairing instinct. Human backs are expressive psychological indexes, but wagtails speak, argue, expostulate, and declaim with their tails. Wrens, robins and thrushes are fairly well distributed, but nothing is to be seen in these parts of the autumnal migrations of the younger robin generation, the country being far too open for them, and the succulent smoking manure heaps appealing more to starlings and finches. Still, we have about a dozen residents. The pleasant sparrow vespers to the declining sun are music that London could ill spare.

Omitting the gulls, our remaining large land birds in the autumn are the mistle-thrush, kestrel, carrion crow and wood-owl.

The wood-owl is with us practically all the year round, and probably nests in Richmond Park, for not only does it nightly enliven the darkness with its wind-in-the-chimney music, summer and winter, but often brings young with it in the autumn, whose kee-rwick, kee-roick alternates with the deep, hollow notes 
of the parent. During the late summer of 1920, a tawny owl used to perch on a sycamore tree: near my window every day at dusk, befor, setting : o:rt darkling for the chase, and I once flushed orie of them from a cedar in private grounds at mid-day, and he departed in full hooting trim. It is strange that the wood-owl should be so much commoner in London than the barn-owl, whom an imbecile persecution has now made the rarer bird all over England. On July 5, 1920, a yaffle actually flew over my garden and back again five minutes later, the only occasion I have seen this species in London outside Richmond Park and Wimbledon Common. The wandering gipsy parties of mistle-thrushes formed in the summer break up in December, and early in November (1919) one of them (they usually go straight over in parties of about half a dozen) spent a few days in the orchard and on the fields, greeting me with their boisterous, girding cries of derision whenever I trespassed upon them. When their adventurous, masculine spirits urged them onwards, they left a pair behind for several weeks to keep me company, and I once watched one of them amusing himself about one of the orchard trees, circling it, plunging to and fro among its branches, skirmishing about over its top and diving down within a few feet of the ground. The relationship of this air-dog with the susceptible song-thrush is piquant. They are as unlike as it is possible for one bird to be from another, and only buoyancy their share in common, the one in facing perils, the other in recovering from them. There is a poem in my friend Ralph Hodgson's The Last Blackbird which gives the mistlethrush as no other can.

I heard the grey thrush piping loud

From the wheezing chestnut-tree;

The grey thrush gripped the spray that bowed

Beneath the storm, and brave sang he-

$\mathbf{O}$, he sang brave as he were pne

Who hailed a people newly free,

are two stanzas.

1 The parent also kee-twicks, but I made sure these were young. 
The kestrel (one bird) may or may not stay with us during the winter-it depends on the weatherbut in the autumn he is roaming about within half a mile of my house two or three days in every week. Everybody bullies and persecutes him, from the piedwagtail to the black-headed gull (except, of course, the dunnock, who minds his own affairs), and he can rarely hover in peace, but a gull drives him off his pitch or a wagtail puts him to flight, returning when his victim has disappeared, shrilling with self-applause and intoxicated with triumph. Sometimes he hovers right over the buses passing along the river to and fro beneath him, possibly for a respite. He got quite used to me, and often allowed me to come within thirty yards of him and admire his beautiful striated plumage, when perched on the handle of a plough or on a manure heap, or preening himself on one of the white posts on the recreation ground, or on the transverse bar of the goalposts with that proud, statuesque air all the raptors, except the buzzards, have. Or he would be flying leisurely on pointed wings and oaring his slender shafted body a few inches from the ground, or suspended in air with pulsing wing-beats. To other birds he never pays the smallest attention, except to give dignified place to them, though it is hard even for him to look the fine bird he is with a feather-headed wagtail screeching at his heels. It is always a puzzle to me to understand what the kestrel expects to find on a bare patch of ground his eyes peer down upon with such intentness. ${ }^{1}$ Would not any sensible mouse remain in hiding with this deadly slayer of his tribe hanging over him like Damocles' sword? Yet there he is, as absorbed in his researches as St. Jerome in his study -like a newly released soul taking its long, sad, farewell gaze at the seductively wicked world before leaving it for the arduous virtues of a better one. In February 1920 our kestrel disappeared, and at the end of the month returned with a mate, while on July 5th a young bird flew past me and alighted on a

1 He probably feeds on grubs, beetles, cockchafers, earthworms, etc., as well as rodents. 
tree, calling his quaint squeak. Presumably, then, the parents nested somewhere in the south-west, though $I$. have no idea where.

But the crow, the only disreputable or reputedly disreputable member of the whole suburb, except me and the cats, is the black angel of the fields and allotments. He is one of the very few species which has increased with us since Mr. Hudson wrote Birds in London, and in 1919 our pair safely brought off four young from a nest in the top fork of a tall elm almost opposite my house on the Middlesex side of the river. The six of them kept together, cruising the neighbourhood throughout the summer, autumn, and winter, their corvine wisdom being perfectly well aware that these monotonous fields are a Jerusalem of safety and abundance for them.

I have seen as many as nine of them together in the air, shouting, flying races and buffeting one another in mock-battle, as many as twelve on the fields and twenty-one feeding together on the river ooze in the autumn of 1920 ; doubtless sevcral families joined forces. It is interesting to observe the crow resuming its ancient social habits, broken up by man everywhere else in England except perhaps in a few of the wildest districts. And I think that the birds gain by this in temperament and character, expanding and fulfilling their individualities in the broader milieu of social life. Kropotkin was a wise man when he said, "Man did not make Society, but Society man," and animal sociability has undoubtedly been one of the greatest, perhaps with the exception of parental care, the greatest driving force of progressive evolution.

Here the crow is a plump, lamb-like creature, for few temptations come his way, and he fully satisfies his hearty appetite by varying a grub with a vegetable diet, trundling down to the river at low tide to play the gull for pickings both on the water and the mud, when he wants to dine out, or the larder is bare in cold weather. So comfortably does he live that he has sloughed off all his rustic cunning and wariness, and with the easing of the struggle for existence, is on 


\section{BIRDS OF THE COUNTRYSIDE}

very tolerant terms with the rest of the feathered. But this "O sweet content" has not made him in the least gross and aldermanic. What it has done is to divert the energies he expends in the country to keep a hold on life into channels of enjoyment. Gravely stalking the fields, he will suddenly explode into hoarse thanksgivings, craning out his neck, ruffling his plumage and roaring away for minutes at a stretch. Or he will balance himself on the tops of the cabbages and duck and flirt his tail to keep himself on. He makes shameless love to his wife half the year round, and with as much youthful gusto in the summer as the spring, before his offspring or out of their sight. Sometimes, out of sheer abandon of spirits, he makes passes at the gulls, snapping his mandibles at their necks when they are feeding on the ground, and desisting to soar and gambol in the air in madcap frolics with his family. These crows of ours will chase one another in flight like clumsy swallows, and, though they cannot dash down wind in the giddy way small birds do, there is nothing they enjoy more than setting their vans to the wind and down slanting to earth with a rush. Both parents and young have quite laid aside their hatred of the human form, and, as though they enjoyed giving Darwin the lie, allow me to approach within ten yards or even less without turning a feather. Even when I walk right in upon them, they are in no way disconcerted, flopping leisurely off a few inches from the ground, to come to earth again some yards further on. Elsewhere the crow is all at odds with the world; here he is on the best terms with it.

An incident I witnessed in October gave me the crow's measure better than any other in my experience. Four of them were ambling about some fifty paces from me, and what seemed to be the tail of another came out from behind a tussock. It proved to be an all-over black cat, and the black cat was in a great taking over the black crows. It would stalk one of them and then make a flying leap for him. What did the crow do? He gazed contemptuously at the 
cat, and when the assassin was upon him, gravely took a couple of sideway hops out of reach and turned his back on the enemy of his race to tickle his craw with a leather-jacket. This happened again and again, and each time one of the crows evaded the cat's rush with a mixture of ease, calm and mildness and an air of "what ails you, my good friend?" ludicrously discomposing to the cat. The others, who made a circle round the cat, either took no notice of it at all, or threw a compassionate glance over its way, and then back to the grub. Now and then they all stopped feeding and gazed at it as we might at some person making a fool of himself and not aware of it. At no time was the cat distant more than three or four yards from any of the birds. Finally, the eat simply gave it up and retired, looking so crestfallen that the crows, watching his departure, seemed to pity him more than ever.

This was not the only cat-and-crow incident I witnessed. One day later I saw this same black cat, a thorough picaro, stalking a solitary crow feeding on the ploughland with his back turned to the enemy. Suddenly he turned round, and this time it was too much. He gave a shout of rage, leaped into the air, hovered some feet over the cat (who sat back on his haunches as when attacked by a dog), making stoops within a few inches of the feline nose. But this was only the first act. Finding that the cat was immovable, friend crow sprang up higher into the air and began trumpeting "caws" for all he was worth, paying no attention to the cat. Then, behold, from different quarters came a reinforcement of two crows, pelting along as hard as they could go and shouting encouragement to the solitary warrior. Having joined forces, the three crows hovered down close upon the cat, fluttering their wings, swooping down upon him and singing hoarse battle-songs. This was altogether too much for the cat, who turned tail, walked, trotted, galloped, and finally bolted, pursued by the triumphant crows right into the street, two hundred yards away, when they gave it up. The drama occurred 
exactly as I have related it, and I believe it is worth relating, since $I$ have never before seen so remarkable an example of intelligent co-operation among birds, following upon a deliberate summons for assistance. Whether other people take any notice of our crows, I do not know, but for the constant refreshment they have given me I am truly grateful to them.'

On an iron-bound day early in February 1919, with flakes of snow hurling almost horizontally past me, I met with two pairs of grey wagtails, the first time I had seen them in London, looking like strayed wanderers from some brighter world in their exquisite grey and yellow feathers, ruffled in the bitter wind. This wagtail turned up again next winter, and this time a mile nearer in. I saw one running and feeding along the embankment on December 22nd, and four days later close to the same place, but flying over the fields. He has the true wagtailian double note, but it is not so thick and sibilant-altogether brighter and more abrupt. On January 14th I was so fortunate as to meet the grey in the fields in company with pipits and a pair of pied wagtails, and I had a rare opportunity of comparing their notes. When they are heard together the difference is marked, and the grey's twice and sharply struck bell, pure in intonation, is much superior in quality to the more relaxed and consonantal note of the pied. They differ as the duskiness of the one bird differs from the uncompromised grey and yellow of the other. It gives one a rich sense of the artistic progress of evolution to reflect that pipit and grey wagtail both are descended from a generalized type as dull in colouring as the pipits. From it arose the sylph-like Motacillida, as the Ancient Mariner arose like Aphrodite from the sunless expanse of Shelvocke's voyages. Thus nature plays her endless variations upon her plain and single theme of praise, a Cecilia, with her eyes fixed on the courts of heaven.

1 One of the briskest and most intimate accounts of crows I know is in Lieut.-Colonel Cunningham's Some Indian Friends and Acquaintances. 
Had this evil time lasted a week longer than it did, the mortality must have been a heavy one, and, as it was, those oozy shallows saved many of the feathered from untimely death. It is starvation, not cold, that kills the birds-its tooth is not so keen to penetrate their warm wrappings and intensely beating heart beneath it, unless insufficient food and drink can slow it down.

Darwin, it will be remembered, projected a study of natural checks to over-population, and it is a great pity that he did not write it, since it must have very largely modified the paragraph headed "Struggle for Life Most Severe between Individuals and Varieties of the Same Species" in the Origin of Species, a paragraph (with very inadequate evidence to it) mainly responsible for the now superannuated theory that the system of nature is an incarnadined "gladiatorial show." It is a great pity, for that theory has perhaps done more harm, inflicted more misery, and sanctioned the rapacious spirit of commercialism more thoroughly than any other idea of civilized times. It would be impossible here so much as to attempt to describe how that theory has been displaced by a broader and deeper reading of animate nature, but it is relevant to point out that, quite apart from the quintessential importance of migration as a method of solving the economic problem of feeding many mouths with little food, birds actually combine rather than compete together when food is scarce. The phenomenon of winter flocks is entirely against the competition theory, and one is inclined to invite those museum specialists with their dismal illusions of nature's fratricidal warfare to step into the open air and watch a winter procession of tits. For one tit in a flock of tits can find more food than if he were solitary, since he depends on a hundred eyes rather than on two, apart from other advantages for self-preservation. The conditions of inanimate nature are equally against the theory. It is a fact that the world is not overbut under-populated by the higher animals-far too under-populated, alas!-and climatic changes operate 


\section{BIRDS OF THE COUNTRYSIDE}

in the most direct and powerful manner to reducing a local congestion of numbers.

I remember standing on the bridge one day towards the end of this bad time, and watching two herons circling over the river among the screaming gulls in front of me, a kestrel hovering on my left hand, flocks of ducks passing overhead (doubtless on account of the freezing of the Richmond and Wimbledon ponds), on my right-hand lapwings, water-hens, star lings, robins, thrushes and blackbirds trotting "on the marge of the angry flood," and in the middle of the river a pair of crows (from the Middlesex side) hovering and making little dashes at the water as gulls do, only much less to the manner born. It would have been an impressive assembly anywhere; in London it was one to make a cockney swell with pride, though the actors thus brilliantly taking their parts were on a starvation wage. In the December of 1920, again, a heavy snowfall one day coincided with a yellow fog. I walked out into the silent fields and stood up to my calves in snow. An invisible heron and shortly after him a crow rasped out their calls, and a company of tufted duck followed a minute later by one of mallard swung out of the day-in-night and, sweeping over my head, passed again, like vain longings, into the unknown. In this life-in-death desolation there was nothing in sight, nothing in hearing, nothing in atmosphere to tell me that I was not standing, a lost and solitary wanderer, in the midst of the Siberian tundras.

For one thing we may thank these recent years of misery and terror. The Yuletide-cum-Pears'-Annual cant has received a mortal stroke. The virus of cold is now faced for what it is, the signal for the death of the children of earth and air, the ally and accusation of our egoism, greed and more merciless indifference. But let us beware of blaming nature for our own frosted hearts, since neither child nor bird need die, did we play the true parts in the drama of the universe which the dignity of our evolution has assigned to us. 
The gulls only keep to the river in large numbers in severe weather, and at other times forage far afield, returning to the river at about four o'clock to roost in their communal dormitory on the river. In the beginning of 1919 I saw a superb flight of gullshundreds of them-returning to roost along the river, all in order, solemnity and silence (usually they fly in undisciplined masses), and formed into every variety of loose position, squares, parallelograms, semicircles, and the familiar $\mathbf{V}$ or rather $\boldsymbol{V}$ shapes-symmetrical dispositions, which yet allowed the fullest scope for freedom and diversity within the bounds of the general law and unity they obeyed. At another time I disturbed a flock of gulls feeding on ploughland, and as they rose in mass it chanced that they hung for a moment over the dark earth in undulating folds about a hundred feet long and twenty broad, like some fabulous flying serpent with glittering and waving scales. Scenes of unearthly beauty come purely by chance in the uncertain world of bird-life, but they come not at all unless one's observations of it are unrelaxing. Thus I cannot count the times I wandered along the river-bank, admiring the gull company wheeling over the river, swimming it and strolling the mud-banks in a ceaseless clamour of high, windy voices. But only once did I see them transfigured (on December 16, 1919) to a glory rarely granted to human eyes. It chanced that afternoon that the sun, lying flat over against the river, heaved the clouds off him and thrust his yellow body through them, sending the wrack flying in trailing wreaths and scarves, like the spray and wash off the back of a risen whale. At once the ooze of the banks was resolved into a floor of burnished gold, throwing off an orange-coloured haze, through which Sinbad's valley came flying a flock of gulls of such supernaturally delicate white and pearl that they became diaphanous, emblems of pure thought drifting through a golden age of meditation. It was the kind of sight that might have converted an unbeliever to heaven. Yet in its way it was only an optical delusion, since without the glass the effect was only beautiful. 


\section{BIRDS OF THE COUNTRYSIDE}

It is a mistake to suppose that we are only honoured with one species of gull, and in bad weather I have noticed no fewer than four within a quarter of a mile of my house-black-headed, common, herring and lesser black-backed, though never more than about a dozen of the last species all told. But in 1919 I noticed two immature brown herring gulls on the flats among a company of about a hundred blackheads on a very warm and humid day in December, so that other species of gull are also founding a tradition of wintering in London, one, too, of determination when young birds help to make it. This assembly was a remarkable one in other ways, for it included four crows, a pair of water-hens, a small flock of starlings, a pair of wood-pigeons, and a dabchick. I had never seen a dabchick on the river before, and its movements were as peculiar as its presence. It was swimming downstream with great speed, diving every minute or so to increase it. Then, when it caught sight and ear of this vociferous crowd, it made straight for them, and at the edge of the water had a tremendous bath, beating up a mist of water with its violently agitated wings. Having thus passed the time of day with the others, it set off again into the unknown, as mysterious to me in its coming as its going.

It is, of course, practically impossible to distinguish the common from the black-headed gull ${ }^{1}$ during the winter, but I noticed that the nuptial black or rather dark chocolate-brown hood of the blackheads was assumed among many of the latter (doubtless the older birds) as early in 1918 as February 1st, a day of implacable snow, and January 7th in 1919. By the middle of March you could be sure that the few capless gulls of the size of the blackheads were of the "common" species, as silly a misnomer as that

1 There is, however, a difference. The primaries of the "common" gull are longer, with white "mirrors" near the ends; its build is squarer, and its bill is without the reds or orange of the blackheads. See T. A. Coward's precise and brilliant manual for further distinctions. The birds are equal in size. 
of the "common" bunting, for they have not a single breeding-station in England. The lesser blackbacks, sprinkled among the blackheads, and illuminating their pearls and whites by the rich contrast of their own dark cloaks, will occasionally busy themselves in the fields, and 1 once flushed one of them within fifty yards of my house. Assuredly, the breaking in upon us cockneys of these wild fays of wave and cliff, like masquers upon a gloomy hall, is a peaceful conquest of nature that prophesies a brighter, if distant future.

I have seen great crested grebes on many occasions all the year round in the district, both on the river and the reservoirs. Their appearances are quite incalculable, and they are quite approachable. My first bird was extraordinarily tame, and it once dived and reappeared in a couple of minutes almost at my feet, when it set to work preening its feathers and standing up to wave its absurdly stunted wings without a trace of concern. All the loons have these short wings, yet some of them migrate over vast distances, and there is nothing to show that their aquatic life is affecting their wingpower. That would only happen if it was no longer of any service to them or they fell into lazy habits. For nature is the most impartial and democratic of mothers, and gives to all her children their opportunities and their perils, and a free will and means to benefit by the ones and escape from the others. As a matter of fact the big grebe uses his wings very much more often than the books allow. On Penn Ponds, where there are three pairs, I have several times seen them in rapid flight a few inches above the surface of the water. Their wedge-shaped bodies enable them, when they alight on the water, to plough through it like a shearwater.

My district possesses both a pond and a reservoir, but the water-hens wisely keep to the river, disappearing (in 1918-19 we had four) in March. But the reservoir, too, had its own fame and endowment, being occupied by a large party of tufted duck, pochards, mallards, and coots. No "ornamental water-fowl" these, but at liberty to come and go as they list, 
free both from the fowler who kills and the keeper who cripples, and so a distinction to my neighbourhood in proportion as it is better to receive and enjoy the gift as it comes than to compel and spoil it. When disturbed, they took flight, beating along the water like moorhens, except that they did not touch it and frequently taking extended flights, descending to water with a rush of wings. In the water they look stout and thickset of build, their bright yellow irides sparkling from their purple-black heads with pendant crests, and the stretch of dead white on the flanks, very different from the glowing sheen of the big grebe's breast, lower breast and belly rimming the violet glossed black of the backs rather in the shape of an Indian canoe. They used to dive and bring up their meals from the bottom to eat comfortably on the surface, and thereby hangs a tale.

The tufted ducks fed at various times of the day, and I noticed that Larus ridibundus invariably called upon them at meal-time. To my delight, I discovered that this gull, taking a leaf out of his cousin, the skua's, book, had established a definite, formal and orderly parasitic relationship with the duck he gulled. One day ninety-six tufted ducks were attended by some thirty gulls, and as soon as one of the former went down, a gull placed himself in the neighbourhood. The duck reappeared, and the gull (sometimes a pair of them) left the water, hovered a yard or two above the duck's back, and swooped gently down upon the innocent. Down went the duck again, dropping his food on the surface, the gull half submerging to recover it. The stoop was obviously made with the intention of flustering the duck, a stratagem successful nine times out of ten. The same process took place with the other gulls and day after day. The experimental stage was long past, and yet I believe I have the honour of being the first to record this secret. The food of the duck was neither weed nor fish on the occasions I watched this ingenuity, but so far as I could guess, water-snails (Limnea), limpets (Ancylus), and other freshwater molluses. 
I have observed myself (and Mr. Edmund Selous says the same thing) that the blackhead also pursues lapwings who have picked up larvæ from the ploughed fields. The gull chases the lapwing, who doubles to and fro, until suddenly the former gives a convulsive twist in the air-he has caught the larva dropped by the lapwing. Yet the gulls live quite amicably with the ducks and lapwings; there is neither animosity on the one hand nor fear on the other. The relation (and Mr. Selous's observations of gulls with lapwings suggest the same conclusion) is accepted on both sides; it has become institutional, and the victims accept this tributelevying or Income-Tax-gathering as part of the normal routine of life. Is mankind less or more fatalistically irrational ?

So different are the dingy browns and greys of the female tufted ducks from the strongly contrasted blacks and whites of the males, that at some distance away the two might readily be taken for different species. The colours of females and young, of course, usually represent the parent form of the species, where the males (see Pycraft, Courtship of Animals) have not yet handed on their colour entail to the females. Thus to see the bright male and the dull female of the same species together is an impressive shorthand of the progress of evolution, of the great advancing tide of beauty, rolling up like dawn and then day from the caverns of neutral beginning. It is moving to think of these wild birds of the wild north travelling from their storm-beaten homes in one little group after another, all to the same little stretch of quiet water in London, so unerringly and companionably, and to see them grow, first 7 , then 9 , then 15 , then 18 , then 21 , then 35 in the winter of 1920 , to a final crescendo of 120, with 12 pochard, a bridge (the mantle) of the softest vermiculated lavender-grey uniting with the black tail-coverts and the chestnut head and neck, in their company. The good news of the security of this London water had gone forth. By the end of March they had all gone. Mallards and (once) a widgeon consorted with them. 


\section{BIRDS OF THE COUNTRYSIDE}

The skylarks rarely left the fields. I had a remarkable experience with these larks. On January 29th (1919) I disturbed a round hundred of them from a large turnip field, and instead of flying off close to the ground with their loud, thick, guttural chirps of alarm (which are woven into the song when heard close at hand), to alight further off, as is their usual custom, they massed into a dense column and began to circle round and round me. The flight was an undulating one, and the birds would sometimes dip almost to the ground and sweep up from it again in an intoxicating surge of brown bodies. They continued their aerial evolutions, wheeling and looping round my head for nearly four minutes. Finally the whole flock came to the ground some twenty yards from where I stood, and wonderful it was to see how they did it. They did not drop to the ground in a shower as linnets do, but swam down to it, the vanguard ranks of the column sweeping low and parallel to the ground, slowing down until they came almost imperceptibly to rest, the higher ranks behind them curving down to the same position and so on until all of them were on the ground. Never for a single moment did a bird of them fall out of his place, and I was able to observe the continuity of the slope right up to the moment when the foremost ranks came to earth. As they flew round my head they kept on passing a large brick building fifty yards away, and the browns of their backs would leap into vision as the birds passed between it and me and fade into duskiness again as they came out against the sky. If this was not the most beautiful, it was certainly one of the strangest displays of bird-life I have ever seen. I was grieved to see that the larks were less numerous in the winter of 1919-20, and their numbers, as I carefully ascertained by repeated countings, at no time went beyond sixty. One of them was splashed with white instead of tawny on the margins of the feathers of the back, so that by the time these words are printed I suppose some pedant will have him in a glass case. Linnets 
are sometimes to be seen on the river tow-path, windtossed balls with ambrosial voices. Strange to meet such a bird in London. Possibly the linnet is the most amiable of all living creatures, including man. The jealous exclusiveness of the love season affects him not, his volatile spirit is all neighbourliness. The linnet is the moonstone in the crown of nature, yet for all his fragility and gentleness, he lives and thrives, while Dinotherium, Monstrum, horrendum, ingens sleeps for ever in the vaults of the British Museum.

I occasionally saw rooks (no doubt from the Richmond rookery) in very small parties, but they rarely traverse this district, and are only passengers when they do. The sparrow-hawk, again, is much rarer than the kestrel, but I have seen one three or four times flying by. On one occasion it passed right over my house, hotly pursued by a gallant party of pied wagtails. Four of them dropped out, but the fifth still maintained the chase, to return, tossed down the wind, in a babble of triumph. What are the stories of knight-errants overwhelming ogres, giants and dragons to the dauntlessness of this Lancelot of the Passerine Order, leaving his fellows to go hue and cry after the invincible enemy of his little nation, since no family cares steeled his fiery heart?

Fieldfares are very irregular visitors and only birds of passage, though I very occasionally flushed a few from the orchard in the winters both of 1918-19 and 1919-20. In March 1919 I once saw a pair of redwings fly into the open fields from the orchard, fly and disappear westward speedy as thought (they are the fastest fliers, as they are the handsomest of the British Turdince), and that was the first and last I ever saw of them. Early in February 1919 I had what I believe is a unique experience. I was watching a large assembly of finches feeding from piled manure heaps on the Middlesex side of the river, when I saw to my glad surprise that among the sparrows, chaffinches and greenfinches there were thirty tree-sparrows and bramblings, the males of the latter, with their fawn breasts, mottled white rumps and upper plumage 


\section{BIRDS OF THE COUNTRYSIDE}

slashed and chequered with orange buff, chestnut and white being easily the first and boldest in beauty.' Bramblings are an uncommon sight anywhere in England during the winter (they nest overseas); in London I doubt whether they have been observed anywhere for the last twenty or thirty years. Passer montanus is a much prettier bird than Passer domesticus, and easily distinguishable from it by its sleeker plumage, comelier shape, chestnut head, white collar round the neck, and conspicuous double wing-stripes. Unlike the house-sparrow, too, he does not "affect neighbourhoods." Ralph Hodgson told me he found a lesser redpole's nest within a dozen miles of the centre of London, and Mr. G. A. B. Dewar relates in Wild Life in the Hampshire Highlands that the butcher-bird and tree-sparrow nested the same distance away in '98. I found my bramblings and tree-sparrows less than six miles from Charing Cross, and they stayed for the rest of the winter except to make a migratory movement in March (si magna licet) over to my side of the river within two hundred yards of my house. But they failed to return in 1919-20. Lastly, to write "Finis" to the winter with a flourish, I have seen both the common snipe and the wheatear, the one within one hundred and fifty, the other two hundred, yards of my house. I flushed the snipe on November 18th of last year from (of all places) a cabbage field, and, giving its strident cry, the bird zigzagged off in its Chinese puzzle flight high up over the houses and the road where the buses run. Snipe, then, are not exclusively confined to marshy ground; even the Charadriida, so specialized for particular localities, are capable of changing ground. This bird was probably an immigrant from abroad, strayed from its course. The wheatear I saw on ploughed land on March 13th, and it was gone the next day. The wheatear has been recorded two or three times, I believe, in London, but

1 The winter plumage, of course, is more obscure than the spring, the brilliant contrasts being edged over with minute wavelets of brown feathers. 
never so early as this. He got his name into the papers ! Such visitations from birds of marsh and virgin upland do indeed blow away the missish stuffiness of Suburbia.

\section{III}

The spring with us is not by any means the season of rejoicing and renewal it is elsewhere. The sombre, brown fields hardly smile when warmer airs fan their weather-beaten cheeks and trees, bushes, hedges and wild flowers are too few for a profusion of "budded quicks." Apart from the trees, we have little, outside a few hawthorns, to measure the season by except the elderberry. In the babe-like winter of 1919-20, the stiff, metallic, coppery-green leaves of this somewhat surly and plebeian plant were out in the first week of February, and in the middle of January in 1921. It is by loss, not enrichment, then, that we measure the retreat of winter, bawled at and buffeted as he yields a reluctant field to the March winds, like mistle-thrushes driving off a hawk. For the winter congregations gradually break up and steal away, reintegrating if the temperature drops, yet leaving us poorer almost day by day, and only returning when the nesting season is over. Blackbird, dunnock, ring-dove, throstle, robin, tits, starling, crow, and, strange and handsome to record, linnet and yellow wagtail, alone nested with us. A pair of larks remained the whole year, but I never found their nest, if they had one. Rarely if ever do these nests escape robbery, but it was a sore thing to find the linnet's nest in the orchard destroyed and the bluey-white eggs, powdered with chestnut and purplish-red spots, taken. In London one sees more of the autumn than the spring migratory currents, and the only time I heard or saw anything of the latter was on February 25, 1919, when the sounds of a great migrating host (mixed waders) billowed across the night sky. I was out in ten seconds, but could see nothing, though the night was cloudless. To stand out in the great vault of night under the "bright patient stars": and 
hear the cries of the rushing, winged travellers drifted upon one from the well of darkness is to be penetrated not only by the unsolved mystery of migration, but the sublime miracle of all life, until the whole being responds. Thus do we pass onward from the darkness of birth into the darkness of life and death, speeding forward, and unknowing why we travel, what we pass, and whither we go, guided only by the spiritual stars within the firmament of night.

One curious nesting phenomenon I must not omit. I have found half a dozen thrushes' nests built on the terminal branches of large trees, fifteen and twenty feet above the ground. This must be the result (1) of the few suitable nesting sites hereabouts, and (2) of their nests being invariably destroyed. Now, if the birds brought off their young safely by this new fashion, the variation would be seized upon by natural selection and perfected into semi-automatic instinct, and the bush-building habits of town-thrushes would entirely disappear. The change is as revolutionary as if special conditions made it necessary for a certain village to build its houses underground. Darwin gives some interesting nesting variations in his posthumous chapter on "Instinct," and they are examples of what Romanes calls "plasticity of instinct." I prefer to call them examples of intelligence by which hereditary instincts are not only modified, but discarded by the associations and circumstances of the individuals of a species.

Thus impoverished by the departure of the birds, we listen for the first songs of our resident birds with an intentness sharper than in the country, and when we hear them, familiar songs from familiar birds, it is with a satisfaction not achieved by countryfolk with their nightingales, just as light seen through a chink may set the emotions vibrating more than the whole visible day.

Of late years, I personally could not feel in accord with the throstle's song, which, intermittent with us Londoners in a mild winter (I have heard it all months except August), breaks into its full volume of 
sound by March. Somehow the very innocence of the throstle's song, his brilliant, varied, luxuriant declaration of care-free gladness, lack meditation and tenderness. We are now so burdened with memory, so appalled by the misery of our own world, that this hey-nonny of a "too happy" bird is as remote from us as the equivalent Elizabethan madrigal. A sorrow to match and express our own we shall not find in nature, but the throstle's very exuberance of joy seems to mock and reproach us.

It is otherwise with the blackbird, whom I first heard on February 22nd (1919) at seven o'clock in the morning, and in 1921, actually on January 26th. I remember reading somewhere an observation that the blackbird's flute is less a song than "a refined and spiritualized soliloquy." The writer never said a truer thing, for those calm and leisurely intonations are not those of song, but of talk, and the very imperfections and breakings down seem like the prosiest portions of the narrative, the plea, the description, the dramatic monologue, whichever it be. The speaker, for all his eloquence, is not a trained rhetorician. It is as if his tidings were of things of too fair a report for the vehicle of sound to convey; his technique is not adequate to them, and his appreciation of these marvels make him fragmentary, incoherent in his effort to express them.

I think the reason why this music moves us even more than its beauty warrants is twofold. In the first place, the break with winter is not too abrupt. Unlike those of July and August, avian voices are never silent in winter. The pied wagtail along the river utters his bright, sibilant double note as he hurls himself through the air; the meadow pipits ring their fugitive elfin bells; the robin's thin silver spears of melody pierce the mirk; the tits clatter among the tree-tops, and seem, like Dr. Johnson, to be always drinking tea, so like are their vivacious notes to the rattling of cups and spoons; the tawny owls cry like the night wind in the rigging and down the chimney; gulls and lapwings are the bagpipes 
of storm; the larks in flocks on the allotments utter their strident, grating alarm cry; the starlings are a Parliament of Foules, composed wholly of their own party; the wren gives us his sweet, running, precise phrase-and so on. Everywhere the winter hums with talk, friends' talk and business talk both, and all at once the blackbird chimes in with the transition from the workaday world to the ideal one. Secondly, the blackbird's rich contralto has a reflective and even melancholy-seeming cast more in touch with human emotion to-day than the throstle's effervescence. As I lay and listened to him it seemed impossible that I should soon get up, eat porridge and read of the villanies men do to one another.

Within two yards of me in the garden I have the robin singing "inwardly," as Gilbert White would say. This subdued and delicate warbling is quite different from the usual song, or the tet tet of indignation, or the sobbing gasp uttered when the nest is approached. It is so faint as to be unheard ten yards away, and rather like a series of vocal sighs crept into melody-airy bubbles of sound, a song in music what pearl is in colour-how can one describe it ? The great tit's spring song I first heard on January 28th, in 1919, and the blue-tit's as early as December 1920. The former is a high and low note, loudly and rapidly repeated, sometimes twenty times, somewhat metallic, and uttered with a jovial, consequential air admirably suited to so virile a character. Blue-tit's welcome to the season is only a single note, likewise volleyed out in quicker sequence still, and with a prelude of three notes, with longer intervals between them, but it is much purer and sweeter in quality than the oxeye's song. By April the dunnock is singing all day long, and will so continue for months. In the wonderfully mild winter of 1919-20, indeed, he sang regularly from October to March. A sentiment clings to this temperately gay song, which finds its way even into books of the ornithologists of the collecting sort, as they industriously cart into them their rubble of tedious facts compiled at the expense 
of so many lives, vastly more poetic than theirs. The lark's song I first heard out of a yellow fog on February 9, 1919, and in 1920 as early as the 16th of a very mild January, gushing down upon the earth "where men sit and hear each other groan" in a shower of golden rain, rustling down and splashing where the guttural notes sounded above the more liquid ones.

The lark's felicity is not earthy like the throstle's, and its exultation is purely of the care-free heavens. Our own mounting hopes and escaping thoughts seem to climb that invisible staircase of sound and motion up which the lark ascends and from which his music descends. For neither song nor bird seem of this world. Yet our conception of angels is that of inane debutantes in nightgowns, with wings growing out of two slits in them, borrowed from the "lower animals" who are not admitted to the joys of supramundane existence.

It is usually said that larks stop singing in midair, and drop like a stone. But they by no means invariably descend in this manner, and $I$ have often watched them in this neighbourhood come sliding down in a long curve, singing and vibrating their expanded wings until within a few inches of the ground, when they hovered for a moment, and only ceased singing when their feet actually touched the ground. The season of larks singing in numbers only lasts with us between the first impulse to song and nesting time in the first week of April. I have noticed that larks, like other singing-birds, differ from individual to individual in the quality of the song.

The chaffinches, whose numbers accumulate to many more than a hundred, disappear from us before their marital music begins, though in the variable winter of 1919-20 they began singing as early as February 24th, without, however, the dash and audacity of spring. Thereafter, I am at a loose end for birds, except for the courting displays of the crows, chasing one another from one chimney-pot to another, and the music of the owls which $I$ hear every night as 


\section{BIRDS OF THE COUNTRYSIDE}

I sit in my study reviewing minor verse. The pied wagtails depart for the nesting season and return again after it, so that it is rare to hear their spring warble delivered like that of pipits and wheatears, while hovering some feet from the ground. But it is not true to say that they do not sing in the winter, for I sometimes used to hear their cheerful, hurried and charming song, in the same notation as dunnock's and swallow's, and uttered not in the air but on the ground. I have never heard the mistle-thrush sing in the winter, here or elsewhere, and it is my belief that he is, like the blackbird, invariably a harbinger of spring, the loud, ardent, assured and assertive messenger of the first dawn, the early streaks-like the daffodil.

Except for swallows, martins and swifts, we see and hear practically nothing of the migrants, though willowwren and chiff-chaff sometimes spend a few days in the orchard before passing on, and cuckoos now and again fly over the houses and fields.

There are, however, exceptions. In June 1920 a pair of yellow wagtails nested in some waste land, tangled with oxeye daisies, parsley and mayweed, between Snipe Field and Wheatear Field. Whenever I approached the nest (once found, I kept some distance away from it, for fear of attracting attention to it) the birds would fly round my head in broad sweeps, uttering their bright alarm cry-tihee, tiheetrying to entice me away by manœuvring in the direction where I knew the nest was not. It is not difficult to get near these shapely and brilliantly plumaged birds, and they perch indiscriminately on the ground, wagtail-fashion, on the tops of small plants, chat-fashion, and on small trees and tall bushes, finch-fashion, keeping their lustrous bodies well out into the day. The voice is nearer to the grey than the pied wagtail's, and the flight is all curves and undulations. This symmetry of flowing lines is deeply satisfying to the human eye. Nature is a world of curves, as a great biologist says, and we were brought up racially on them. Early in May 
of the same year I saw a lesser whitethroat in the orchard. I was standing quite still under an appletree, and the little bird flew on to a branch three yards above my head, and immediately plunged into frantic song-sipper, sipper, sipper, sipper-two notes rapidly repeated like a row of exclamation marks. So near to the bird, I could tell that it was a trifle smaller bird than the common whitethroat, and more reddish brown on the upper parts. As Mr. Coward points out, the surest way of distinguishing between greater and lesser whitethroat are the much darker ear-coverts of the latter. But you must get a better than a bird's-eye view of him to tell them apart.

The willow-wren slips through the gardens as well, and I have had him back in mine, on August 10th, singing the ghost of his spring lyric in the middle of the day. By the middle of August greenfinches and chaffinches begin to drift back to their autumn and winter haunts, and the swallows and martins (whose final doom comes perceptibly nearer year by year) are educating their families. On the same day that the willow-wren appeared in the garden there was a great congregation of swallows, and I counted one hundred and fifty-three perched on the telegraphwires within ten yards of the house, while fifty others swarmed like bees about it. Then suddenly they were all gone, and ten minutes later the normal number were hawking the skies. It was exactly like a rehearsal for migration, and may indeed have been something of the kind. Several of the martins built nests in the gables of the houses of my road, though not, alas! in mine, and one very late brood was, I have strong reason to believe, deserted.

It is interesting to watch martins house-hunting in a road (my road) where they have built in previous years. A pair of them will inspect one house after another, swooping up under the gables, fluttering before them, and then passing on, unable as yet to make up their minds. Once the site is chosen, the tenants will stand no nonsense from other pairs on their search. In August, the martins begin to flock the skies about 


\section{4}

BIRDS OF THE COUNTRYSIDE

seven o'clock in the evening, fluttering and wheeling like pipistrelles. There is a quite steep cloud of them, and when they have exhausted one space, they occupy the next, slipping further and further away with fainter and fainter cries. These evening flights, however, are undertaken for more than daily bread. They are partly for exercise and play, partly for educating the young birds, and are partly a noviciate in sociability and before departure overseas. For migration represents biologically a radical change in the rhythm of bird-life, and needs almost as much preliminary training as a boxing match.

\section{IV}

I will end this account of the birds of my district by one of those in my garden-the ordinary suburban affair, some twenty-five yards long by eight broad, and with no trees in it above a small plum and apple and a sapling mountain-ash. For this garden, like Sergius, I never apologize, for, thanks to the good cheer and accommodation I provide, it is a winter almshouse for eleven regular, (not counting rare visits by other species) different and needy species-sparrow, robin, chaffinch, dunnock, blackbird, starling, blue-tit, oxeye, wren, throstle and mistle-thrush - a good tally for a London garden.

I have learned a few things by watching these birds which no books have told me. In the first place, it is mythical that sparrows drive away the more delicate species. ${ }^{1}$ On the contrary, they encourage them, since the sparrow, however parasitic on man, is perhaps the most incorrigibly wild of all our native birds, and if he relax his cautionary tension in a garden, other birds give a sigh of relief and throw their anxieties to the winds. The sparrow's attitude is a perfect barometer of safety, and I have never known him interfere with the others, in spite of his large numerical superiority. Mr. Hudson gives a desolating account of the Tower sparrows and their

1 Their appropriation of the nests of martins is of course different. 
hooliganism, but maybe they are tinged with the associations of the place. The remarkable thing about my sparrows is their capacity to learn, the cause above all others of their prosperity. Conceited, aggressive people learn nothing; knowledge comes from patient experiment, humility, watchfulness and readiness to seize the occasion when it offers. My sparrows are not Pelmanites or profiteers, though this taking advantage of the labour of others is Jew-like. But the bad Jew (who is generally behind the luxury trades-brothels, fashion, cinemas, etc.) preys upon the vices and frivolities of men; the sparrow lives on the specializations of others and does the work, which is quite unlike the parasitic money-getting of, say, the fur-trader. Not only do they keep in the background, alert, judicious, capable and unobtrusive, but I have never known them to take the initiative in anything. They wait and watch what others do, and then if it seems good to them, and being quite catholic in taste and without prejudice, they go and do likewise. Thus it was the blue-tit, robin and starling who showed them the way to feed from the bird-table-sometimes, as I have seen, driving their pupils off it; blue-tit and oxeye to perch upon the portholes of my hanging box, thrust in their heads and extract the oatmeal from within; the thrush who instructed them in the joys of the same food on the ground; and blue-tit and oxeye, again, how to grasp the rind of a cocoanut with their feet and hammer down (as now they do regularly) upon the succulence within. They are the least professional and specialized and the most elasticminded of the whole passerine order, and their ability to profit by the specializations of others is unmeasured. All these experiments are conducted in unbusinesslike, shoddy, hoydenish fashion, for the sparrow, being a jack-of-all-trades, possesses no technique to any of them. He is the casual labourer of the race of birds, and it is to his capacity for doing any mortal thing in a second-rate way, to his acutely intelligent observation of the habits of others and decisiveness in acting upon what he has assimi- 
lated, that I attribute the wonderful hold of his tribe upon life-rather than to the mechanical factor of prolificacy.

Indeed, as I study the birds in my garden, I fall more in wonder of the infinite variety of nature, psychological variety not only of species, but (as I hope to show later) of individuals of the same species. How uncommercial-minded the individualist robin is, for instance! That spruce form, that gallant and fiery spirit hardly gets a tenth of what blackbird, thrush, tit and dunnock do in the same time. He is looking out challengingly for a rival all the time, and is as far removed from scrambling, happy-go-lucky, child-like starling, contented dunnock, vulgar sparrow, cheerful, industrious kittywren, and insatiably curious, active, elfin tit as the sparrow is from his fellow-finch, the linnet. I have had as many as three male robins in the garden at the same time, and though they do not often come to blows, their exclusive tempers will never suffer one another's presence. The usual procedure is a singing contest. One will perch on the fence, the other on the plum-tree at the other end of the garden, and then each will hurl bright, furious spears of sound at the other, one bird always attending with concentrated jealousy upon his rival's musical charges until the end, when he takes up the burden. So the lyric duel continues, until they have worked themselves up into a mood for arms, and one of them, whose conviction of rightful possession is stronger than the other's, quits his perch and advances upon the other, his red breast puffed out like an ensign of battle. I find that the intruder usually gives way and flees, pursued over bush, over fence by the bird whose saeva indignatio has flamed as red as his breast. But occasionally the battle is joined, and a Homeric business it is, though never in my experience with fatal results. Still, there is no doubt that robins do very occasionally fight to the death, being in that respect unique (except for the raven) among British birds. 
Thrushes and blackbirds interrupt their feeding by their wooing, and I have seen my golden-daggered cock-blackbird chase his mate away from the garden, she alighting on the fence, and he within a foot of her, to swing up his tail in that slow, large gesture like a fine line of blank verse, and thus pursue her from fence to fence out of sight. It may indeed be all dalliance, but there is no mistaking the reluctance of his sooty brown mate. The hen blackbird has just that undeveloped, indeterminate vesture which fits the dusky raw material of bird-life in the Cretaceous period. It is this kind of thing that makes me feel the wonder of evolution-that the golden oriole, both material and symbolic, is of the same tribe as the hen blackbird. As colour is developed from drab, so mind out of vague desires and gropings.

Birds need water in the winter as much as they need food, and I made a bath for them out of the lid of the dustbin. The starlings who came to the garden in daily troops of twenties and thirties are adepts in it, gamboling in it, showering and disporting tremselves sometimes six at a time and sending the water flying in all directions. The thrush is more demure, but as he improves he must be anxious to learn the abandon of the starlings. The blackbird I have never seen dare the main, but tomtit and oxeye plunge starlingwise and caper about like children in the sea. The sparrows are learning by degrees.

Wren and mistle-thrush are rarer visitors, and when the latter does put in a very welcome appearance, it is at twilight when the other birds have departed, to indulge in a hearty and solitary bathe. It is remarkable to see the wren at all in this hedgeless district, but he does look me up now and again, and though he will touch nothing of my varied fare, has come within a couple of feet of my window, and sometimes bathes, beating the water with his wings. I have had as many as half a dozen blue-tits and four oxeyes in it at one and the same time. Nothing comes amiss to tomtit, and he will stand on the table sampling one dish after another, to retire at last grasping a 


\section{BIRDS OF THE COUNTRYSIDE}

grain of oatmeal to a twig of the plum-tree, there to clutch it in his claw and tear it to pieces with his bill like a hawk. Meanwhile shuffle-wing comes upon the stage and makes a few shy pecks. But tomtit reappears, and shuffle-wing at once gives place to him, waiting in patience until the Blue Boy has finished his inspection.

On a bitter day early in February 1918 oxeye astonished me by a nuptial dance on the fence, drooping his wings, curling out and stiffening his feathers, stretching his head out low (as a cow does to smell the earth) and tramping down upon the wood in a kind of prancing capriole delightful to the appraising taste of his lady sitting by. It is with birds in love with their mates as with artists in love with the world-they obey the law of making the most and best of their material. The speed with which these tits feed, their sudden pauses to look up, round and ahead, the precision, energy, brilliance and facility of their movements, the volatile change from flight to bodily motion and again to flight all in one unresting wave, like a seventeenth-century "heroic pastoral," without end-stops or Ralph Hodgson's Eve, bring it home to one at what high pressure they live.

In the late summer and early autumn a few young birds drift through the gardens on their way to the sea. I had never seen fly-catchers in London, until one morning in July two young birds alighted on my windowsill and there remained for ten minutes, lifting beaks to the rain, as though it were larval or aphidian manna dropped from the Celestial Bird-Mother. Their mother in the flesh found them at length, and, scolding them for thus exposing themselves, took them off with her. A willow-wren with three young ${ }^{1}$ remained for a whole day in early August, and these casual visits

1 Young willow-wrens are brighter than the parent birds, which is an exception to the general rule that the young of a species approximate to the ancestral form. The breasts of young robins are spotted, one sign of relationship between the robin branch of the warblers and the thrushes. 
made me wonder whether family parties of migratory birds do not often travel more or less on the route of migration, and so gradually converge in some numbers. A hen robin with three young was another visitor remaining for two days. She used to sit and sing to her young or croon to them in a murmurous undertone only audible at about ten feet away, and quite different from the male's song, or rather songs. Do the hen-birds of other species thus musically whisper to their young? In the mating season it is natural that the hen-bird, the more passive and conservative in character (anabolic) and reluctant in passion, should be nearly always songless. But the maternal passion is as powerful as the sexual passion of the katabolic male. If hen-birds can or do sing, that is to say, it would be in the intervals of conducting the young and at a time when they are able more or less to fend for their own living. Lastly, a pair of whitethroats (adults) haunted the garden for three days at the beginning of one September, pursuing their daily round with a composure divertingly unlike their usual spirits. So conspicuously is the metabolism of birds effected by the changing acts in the theatre of the seasons.

Two pairs of blue-tits nested in my garden in $1920,{ }^{1}$ and numerous as are the observations of these drolls en famille, I cannot refrain from trying to communicate portions of the charm of my own experience. Both pairs were on the best of terms with their landlord, and, when the young were hatched, would fly to and fro from their boxes with my head leaned against them. The hen is a close sitter, and her spouse exhausts every argument to persuade her into the sunlight. But she (the singular must do for the plural) was not often to be blandished from her little white eggs, starred with chestnut, so that he would either fly in or his vociferations became so importunate that out she would fly and off they

1 Not to mention a pair of robins, who had filled an old kettle with nesting material by the third week in tropical February 1921. 


\section{BIRDS OF THE COUNTRYSIDE}

would go together. Occasionally a tramp would appear on the scene-a sparrow perching on the top of the box-and instantly she flies out at him and sends him packing right out of the garden. Once an oxeye called at the box with a view to tenancy while the rightful owners were at the other end of the garden. The air became electric: the hen flew straight into the box, and the cock fell upon the oxeye, who put up a semblance of resistance for a few seconds and then took to his heels. But I never witnessed the smallest unfriendliness between the two pairs nesting in the same garden within a dozen yards of each other. Yet if Mr. Eliot Howard's fantastic theory (as I cannot but call it) in Territory in Bird Life were true, these pairs should have been in constant and severe combat through trespassing. The most patient of observers, the ablest of men, fall into perversities as soon as they treat animals as automata, as pawns of complex biological reaction and peremptory inheritance. He approaches birds, that is to say, as an engineer would approach horses, and to treat the whole psychological problem of bird-sex as a congenital obligation for the effective discharge of the process of reproduction is the same as treating horses in terms of motor-cars. There is a lot in the territorial theory, and the selection of individual sites for breeding purposes does play a large part in the biological change from the Socialism of winter to the Individualism of spring. But Mr. Howard intensely cultivates this part to the detriment of the whole, a not infrequent lapse of the expert. He thrashes his theory until it drops with exhaustion. And all because he regards birds as dominoes on a biological draught-board, instead of intelligent living creatures.

Sometimes the hen would go no further than the plum-tree, and the cock would pop a larval gooseberry moth into her mouth, and she, accepting it with a kind of demure grace, sprang back into her nest. In such fondness and service they passed their crowded days.

The cock was full of marital solicitude. One day 
the pair of them had gone off together, and he returned without her with a caterpillar. He summoned her to come to table-tee-tee-er, tee-tee-er-but she responded not, and he dropped in to look for her, and came out two minutes later visibly disconcerted, called loudly, planted his head in the entrance hole and shouted again. But she came not, and so, swallowing his caterpillar like a sensible bird, he rushed off at full speed, crying out to her in obvious concern. The way in which their lives worked in fitness both to physical necessity and emotional beauty was very seductive. When the male was long absent, she used sometimes to put her head out of the window, peering here and there, and then disappear into her nest. This she would repeat, if he still failed to put in an appearance. The food was exclusively caterpillar or aphides, and both birds refused to touch oatmeal, of which they are very fond in autumn and winter.

When the young were hatched, the labour of these small birds to feed them became heroic, and they both grew visibly thinner.

Work apace, apace, apace, apace, apace,

Honest labour wears a lovely face.

I could never understand how the young became aware of one of their parents' visits before he or she went into the nest. But they invariably began clamouring in muffled, silvery chorus as soon as he or she alighted, whether on top of the box or on a twig within a foot of it-as they often did for an inspection. Could they have heard the foot alighting or the wings beating? Young birds are highly educable, and are not born with too burdensome a luggage of inherited adaptations-the most wonderful of them all, the egg-tooth, an adaptation from reptilian ancestry, being an elaborated tool for one stroke and then lost-but this superacute sense of hearing is one that might very well be an over-specialization and hence a danger to the species. For if an enemy 
trod near the nest, the clamour of the young birds from hearing the footfall would betray them.

Though the process was not systematic, the parents more or less fed the young in shifts, the female on the whole bearing the larger share in a total sixteenseventeen hours' day. But the male, while actually doing less work, accomplished more results by confining his foraging nearer at home than the henbird. This was a suggestive example of male and female differentiation. The female is more conservative, stable and routine-bound than the male; he plays the more adventurous, dynamic, individual part. Why, then, did she go further abroad than he did? Presumably because, in a wilder environment, both parents go further abroad for food than my garden-space represents. But in gardens with fruit trees and herbaceous borders, there are ample supplies close at beak. The male, so I conjecture, recognized this; the female was more obedient to "sub-conscious memory."

The first brood seemed to assume the toga without any examinations, for though they were in the nest one evening, they were gone early the next morning, and I saw nothing of them again except in the middle of the day, which they spent with their parents in a sycamore-tree three gardens away, toing and froing among the branches and drinking large draughts of the intoxicating open day. The other family was less advanced, and one morning in the middle of June there was an irruption of five great tits, parent and four young, taking possession of a new playground. They soon discovered that curious noises (not unlike their own a fortnight before) were rising out of a hole in a box, and they all went pell-mell over to it. They perched on the top of the box, while their parent sat on a cross-piece of wood a yard away, looking indulgently on; and the hen blue-tit, who happened to be feeding the young, poked her head out to see what was going on and then flew away. One of the oxcyes then grew so inquisitive that he perched on a rose spray outside the box. Just then 
the hen blue-tit returned with a caterpillar which she popped into the mouth of the young oxeye and then perched hard by, wiping her beak and preening her feathers. Meanwhile the young oxeye, devoured with curiosity, perched on the edge of the hole and peered inside, its brethren fluttering and shouting with excitement about him. This was the grouping-three young oxeyes clambering about the nesting-box, one perched at the edge of the hole, tilting its body within it to investigate what lay within, and the adult oxeye and blue-tit perched unconcernedly by within two yards of each other. It was precisely as though one family were paying a friendly visit upon another, an agreeable humdrum affair it seemed to them, but what a sensational drama for me! It will no doubt appear that this account is altogether too anthropomorphic. I am relating these events as they occurred, giving them a sub-human setting, because no other interpretation appears to me to fit the facts. "Awareness," says Lloyd Morgan, "is ubiquitous throughout Nature, if here in us in high measure, then in the oak and the acorn, in the molecule and the atom, in their several measures and degrees."

But what intrigued me most of all was the feeding of the young great tit by the parent blue tit. Have we here a possible explanation of the solicitous behaviour of its foster-parents to the voracious, illconditioned, oafish young cuckoo foisted upon them ? Parental care was an experiment perfected by natural selection and riveted by the high survival utility it conferred. Its importance for the perpetuation of the species cannot be exaggerated. Now, I cannot believe (as some observers hold) that the foster-parents are unaware that the cuckoo is no relation of theirs. They are aware enough of other birds, not to mention the adult cuckoo which they constantly and rageingly pursue. The a-sentient egg they do not know for a fraud, but that the young cuckoo is not (say) a young wagtail they know perfectly well. But the foster-parents are naturally compelled to feed the upstart because of the overmastering power and urge 


\section{BIRDS OF THE COUNTRYSIDE}

of parental love, for it is absurd to call so fine and ages-deep a passion, to which they are willing to sacrifice their lives, by a more timid name. And this makes the instinctive conduct of the female cuckoo the most repulsive in all nature, since it exploits a noble passion to the destruction of its own object. This criminal subtlety (analogous to that of the plume-hunter who takes advantage of the devotion of birds to their young to approach and kill them the more easily) probably explains why its victims have not yet evolved a defensive organization against it, as they have against birds of prey.

When I opened the two nesting-boxes, I found four dead nestlings in one and two in another, none of them more than two or three days old. This is quite usual with a species that lays so many eggs. Thus spurts the flame and vanishes, and great Nature pays no heed, her heart and brain fixed upon the roaring looms of life. She is right, and the dead ask of her only the burial of the dead.

Many people will think that the activities of this confined and miniature world are not worth commemoration. But from this same little community of toers and froers in a suburban garden $I$ received what was in its way a revelation. On November 28th I saw a tomtit come into the garden, fly straight up to the window cocoa-nut where the male oxeye was feeding and drive him off it. Oxeye perched upon the bird-table; tomtit dashed at him and packed him off to the apple-tree, and only returned to the cocoa-nut when he had seen his larger and much more powerful cousin to the end of the garden. I took little notice of this incident at the time, until I observed that it was repeated dozens of times with variations right on through the winter. Sometimes it was the female whom this minute, feathered bandit tried to expel. But she generally resented it, and spreading her wings and stretching out her neck opposed a solid defence to the aggressor. But to do so she had to leave the cocoa-nut and tomtit, unable to drive her away by circling round her, would fall 
upon the cocoa-nut instead. What had happened was not a casual but a regular displacement and reversal of power between these two particular male birds, the discomfited one not only belonging to the largest and strongest species of the tit family, but one notorious for its boldness, resolution and pugnacity.

What is the explanation of this? Physical disability I can dismiss at once, for the oxeye was perfectly healthy. I can see no other but that of the individual differences between birds of the same species, differences as great upon their plane as human ones upon theirs. This particular tomtit was very much more of a tomtit than this particular oxeye was an oxeye. Birds, in fact, are variable individuals, each with its own peculiar composite of character.

But this is only a negative statement. The personal reality of the living universe is the thing - "personal agency," in the words of Professor Pringle-Pattison, "is the only clue to the mystery of existence" - and the emergence and development of personal agency both from the life of the race and to further its ends and growth ("Everything for the species ; everything by the individual ; nothing for the individual," as Cresson says) is one of the greatest products of the evolutionary process.

By what process, again, have species evolved and perpetuated themsclves in all their differences from primitive forms? By luck, mechanical adaptation, brute force or fertility? These are a very dry and poor soil for the flower of life as we see it to grow in. No, it is by individual effort, resource, character and initiative, profiting by the variational genius of the germ-plasm, by learning how to live, as Genus Homo learned how to be a man, by no other way than the development of his mind. "The living organism," as Professor Thomson says in The Bible of Nature, "is characterized by the power of effective response." It is the call upon life which comes from without, and upon the response of the living creature to the summons depends the history of evolution. 


\section{BIRDS OF THE COUNTRYSIDE}

"I cannot," writes William James, "but consider the talk of the contemporary sociological school about averages and general laws and pre-determined tendencies, with its obligatory underrating of the importance of individual differences as the most pernicious and immoral of fatalisms. It is almost incredible that men who are themselves working philosophers should pretend that any philosophy can be, or ever has been, constructed without the help of personal preference or belief or divination."

And again: "Not an energy of our active nature to which it (the personal and theistic view of life) does not authoritatively appeal, not an emotion of which it does not normally and naturally release the springs. At a single stroke it changes the dead blank it of the world into a living thou with which the whole man may have dealings."

For me a blue and a great tit feeding from a cocoanut by my window animated the universe into a living thou. 


\section{CHAPTER VI}

\section{A DORSET DIARY}

THE country I am writing about extends in a rough 1 semi-circle some few miles inland, with the undulating road (half a mile behind which lies the sea, breaking beneath chalk and blue lias cliffs, crowned with sheep-walks and small commons) between Bridport (Hardy's Port Bredy) and Lyme Regis, which is on the Devonshire border, for a base. There is nothing spectacular in the country at all. It is poorly timbered, waterless and highly cultivated in the valley pastures by numerous small farms. Ranges of hills, here and there linked to form a miniature turf downland, grow up out of the valleys in every direction. They are steep but of no great height, and many of them of odd rather than graceful shapes. Indeed, the only "features". of the country are the cottages in its straggling villages, built of Portland stone, with masterpieces of thatch, and the unkempt little cider-orchards which are the suburbs of every village.

Yet I grew so intimate with this sober but cheerful land, bare and lonely, but tenanted, wild but homely, unambitious, but packed with character; I came to recognize every field, wayside tree and hedgerow with such increasing love, that I would rather lie buried in one of its untidy orchards than in Westminster Abbey. The better I came to know it, the less I troubled about its extrinsic beauty of appearance, any more than a man does about the good looks of an old friend. I learned it, I had it at my fingers' ends in every mood of wet and fine, but I could no more express nor communicate what it taught me than I could endure to lose it. Though I am now far away from this corner of Dorset in time and place, I did leave something 


\section{BIRDS OF THE COUNTRYSIDE}

inexplicable behind with which I can always get in touch, whether voluntarily or through no will of my own.

October 16th (1918).-A distinguished day. I saw for the first time here a wild raven. It flew low over my head and disappeared over the edge of the cliff, vigorously mobbed by a pair of rooks. This raven exists in legendary account among the numerous small villages inland and by the coast, but I have never met with anyone who saw it in the flesh. Needless to say, I kept my privilege to myself. I never saw this splendid, traditional bird again, and indeed $I$ can scarce credit the fact that I did see it. So far as I know, there are no near breeding-places of the raven on the coast. Perhaps I had been walking, not from the village to the sea, but from the present to the past, from the extraordinary to the normal in bird-life, to a time when ravens grew like blackberries in the fields of the air. On some stunted bushes within a hundred yards of the fishing village I came upon half a dozen lesser redpoles, very passive and tame, being, I suppose, tired out after their long journey from the North. In the village the swallows were congregated on the telegraph wires, preparing for migration, and among them was an albino, all over greyish white.

There was a handsome barn along the road, where a pair of swallows were rearing a late brood, and I used to spend some time every day lying on the hay watching the parent birds feed their young. At this time, the young (four in number) were out of the nest and used to sit transversely across an oak beam a foot below the rafters, silent and statuesque until the parents came dashing in like light under the lintel of the door, when they would instantly come to life, fluttering their wings, jerking their bodies over the edge of the beam, and mouths all agape, whence burst a storm of twittering. Now I am quite certain of my facts. The parents had two chicks each under charge, and invariably fed their own pair, hovering before them. ${ }^{1}$ They not only fed

1 One cannot, of course, distinguish the sexes of swallows, but the point is that each pair of chicks was in the charge of a 


\section{A DORSET DIARY}

them thus, but in due rotation, beginning with the outside chick and going back to it, when the inner one had been fed in its turn. Whether this fair dealing and regularity be followed when the young are in the nest or even whether it be the common practice of the swallow tribe I do not know, but so it was here, and the young, though all demonstrating at the same time, never jostled one another or scrambled for the good things. It was touch and go, but I am happy to say that the whole family got away in time. What agony of divided spirit must the parents suffer when the hot, personal devotion is crossed by the mysterious, objective, tribal impulse of migration, crossed, held up, beaten down and finally swept away, and mercifully with it all pain of loss, all bitterness of regret and gnaw of remembrance!

October 17th.-Warde Fowler says that only once in all his years of observation had he seen the grey wagtail away from water. Yet to-day I watched this little Undine, prancing over a cottage-roof, a hundred yards from any water, and that but a muddy ditch. Yellow-hammers had begun to flock on the uplands.

October 22nd.-Taking a short stroll at dusk in the fields I heard a tremendous uproar from the hedges round. It was the blackbirds. The hedges vibrated with their metallic chirps, so that one wondered whether some terrible catastrophe was threatening the blackbird world. There were so many of them that I guessed they were migrants from the north, many of them no doubt to cross the sea. Simultaneously the owls set up their nocturnes; so that the blackbirds were turning night into day and the owls day into night.

October 23rd. - The swallows have not yet gone, for I saw a score of them circling the church-tower of the village. The migration of swallows presents an interesting problem. ${ }^{1}$ The question is this: Do swallows

single bird, and the inference that the father fed one pair and the mother the other.

1 By the exercise of what mysterious faculties migrating birds survive at all is a sufficient mystery. Granted that young birds find their way by inherited memory, how can a sedentary species 
migrate at the approach of rough weather in the autumn independently of any fixed period of departure, or is it scarcity of food that drives them, or do they select a more or less calm day for crossing the Channel ? The question has not been answered by observation, because swallows (like other species) are notoriously irregular in the choice of a time for leaving our shores. Certainly they linger on almost into November in the south-west, when the conditions are kind. But do they wait until the weather becomes boisterous, until, that is to say, their chances of destruction are at a premium? Cold should do them little harm, but storm would mow down their ranks like a machine-gun. Very well, then, they do not thus wait upon disaster, or they would not have survived and flourished to their present prosperity. The supplementary losses due to storm over and above those that annually befall them in manifold forms would have been too much for the continuity of the race. Probably the swallows once did wait thus, but by the experience of catastrophe they contrived to learn a gradual good sense, calling, it would seem, for a good deal of sagacity over and beyond instinct, and fused, by continual practice, into habit. No doubt the habit is still imperfect and the swallows have some way to go before they can become as weathertight and weather-wise as avian prudence and foresight can achieve. If they ever do so learn their job, and (apart from the interference of $\operatorname{man}^{1}$ ) still further minimize their losses, it would naturally follow that they would rear still fewer offspring in a season, it being a truer economy to have fewer young that live than

travel a thousand miles in a few hours? how do birds avoid traveling in circles at night? how do they anticipate weather changes ? how, at twenty thousand feet above the ground, can they tell the end of the journey? Compared with these miracles, the changing of the water into wine reads like a conjuring trick.

1 It is one of the saddest things among all those melancholy reflections that haunt the modern naturalist that the barbarians of France, Spain and Italy are exterminating the swallow, our swallow, loving and beloved of England. It is to these uncivilized races that we owe this robbery. Three million swallows were killed in the South of France for millinery and food in one year. 


\section{A DORSET DIARY}

many more that die, an economy followed by nature among the higher animals. This may be conjectural, but, at any rate, the swallow must have learned something; and the lingering thoughtlessly on into the sudden peril of violent tempest with its holocaust of lives must have been in some measure abated or partially counteracted by some fresh stride of the swallow mind, some original adaptability to meet the stress of conditions making for failure of racial continuity. ${ }^{1}$

Originally, no doubt, migration was a "mutation," that is to say, a brilliant idea, a creative inspiration, a stroke of genius in precisely the sense we apply those terms to the poet and the artist, born by the mysterious ferment of the germ-cells both in rhythmic obedience to the tidal sway of seásonal ebb and flow and to battle with the pressure of unfavourable external conditions (congestion of numbers, inadequate food-supply, change of climate and so on). Then Natural Selection got to work and sifted out the failing heart, the dragging wing, the bewildered sense of direction, on the one hand, while the active, enterprising, plastic organism embodied the idea in perfect workmanship through successive generations on the other-again on the analogy of a poet giving form to a lyrical impulse. Thus the success of the golden plover wintering in the Hawaian and breeding in the Aleutian Islands -a distance of two thousand miles-may be justly compared with a poem that has "come off." The mutation which gave birth to the sublime notion of migration has become of course an instinctive inheritance, but it has to be worked out by the individual organism in its social relations, as the details of an institution have to be worked out. I do not mean that

1 Gatke's obervations of the migration of birds over Heligoland afford pretty convincing evidence that the greater number of the migrants fly from one to three miles high, and so would become more or less superior to weather conditions. But that does not alter the fact that (1) this occurs chiefly in windless weather, and in bad the birds fly much lower, (2) that vast numbers do not attain these elevations as the "rushes" at lighthouses show. 


\section{BIRDS OF THE COUNTRYSIDE}

birds find their way by the exercise of intelligence, acting upon instinct alone, but that the wonderful sense of direction, germinally implanted as an instinct, depends for its effective practice upon the qualities of the birds themselves. The impulse to spring migration, for instance, has been suggestively called a "constitutional home-sickness," and the species which feel it most acutely and employ all their wits and energies to making a success of it will be those that survive and prosper. The fact that some species-puffins for exampledepart and arrive with a punctuality that seems automatic does not affect the argument. For on the one hand they have achieved this punctuality by an experimentalism extending over thousands of years in the past, and sea-birds are much hardier and more independent of weather conditions on the other. And, even though migration works almost like clockwork nowadays, there are still mistakes, confusions and failures remediable by learning the consequences. Migration, again, is a method of "peace by negotiation," a way out of the intensified struggle for subsistence brought about by over-population.

The "survival of the fittest" means no more nor less than the urge and pressure of God knocking sense into hippopotami, men, water-lilies, blue-tits, spiders and roses. Learn the sense to do this and avoid that, and you shall live; refuse to learn, and take the consequences.

Along the beach (which is all shingle and sorry walking) I met with a new and uncommon species here-the greater black-backed gull-a fine sight as he flew close down by the sea, which was dead calm. On the cliffs to the south of the village I watched half a dozen kestrels. They would launch themselves straight out from the edge of the cliff, turn abruptly back, and then wheel sporting to and fro, up and down the cliff-face. Their light reddish-brown matched the coloration of the cliff so perfectly that when hard against it they would magically disappear and as suddenly re-emerge against the sky or a darker portion of the cliff. Probably a young brood, exercising with 


\section{A DORSET DIARY}

their mother, whose rufous mantle their own resemble. The back of the male is bluish-grey.

October 25th. - I wandered along the stream, or rather ditch, which leads through the cultivated valley to the foot of the bare, rolling, down-like hills. Out of a small clump of elms (what Andrew Marvell called a "plume" of trees) flew no fewer than fifteen magpies some thirty yards from where I stood. Among the low alders, brambles, and willows growing along the stream-bank I fell in with a company of travelling tits, strung out in a long line, threading the bushes like rain penetrating foliage, and chirping away to one another, to keep the flock together. All four kinds were there and half a dozen tree-creepers as well; but not, alas! the long-tailed tit, for he wellnigh perished out of England in the terrible winter of 1916-17. In some places the trees were alive with the birds, and they looked like a travelling circus of minute acrobats. That is rather a vulgar comparison, for there was nothing idle or grotesque in their antics. They were extraordinarily engrossed and energetic little nomads, devastating the insect world that lay in their path. A wren sang in the midst of them. He, like the tits, is a small workman, who suspends labour for a moment to express his satisfaction in good work well accomplished.

October 26th. - The sight to-day were the starlings. A flock of about a hundred was moving to a single consciousness across the grey sky. It was like a cloud directed by intelligent force. It would thin out in a long line, bend its extremities into a crescent, and then mould itself into a ball. Then it would divide in two and wind in upon itself in beautiful and orderly conformation. Such manœuvres were never seen among us earthbound men. At the same time gulls in hundreds were drifting in from the sea to feed among the fallows; the rooks (the rookery hereabouts is at least three hundred strong) were massed high in the distance; troops of finches dashed across the expanse, and a pair of carrion crows hoarsely applauded from the tops of a group of bright-berried rowans. It was both an exhilarating and a restful spectacle-our English 


\section{BIRDS OF THE COUNTRYSIDE}

bird-life seen at its freest, most expansive, and rhythmical. The birds all seemed to be falling into measure with the throbbing spirit of the universe. They in their

Pure and circling thoughts express

The greater Heaven in an Heaven less.

October 27th.-The green woodpecker is common here, and I saw or heard him every day, either in flight or upon hedgerow elms or feeding upon ants on banks. Indeed, without seeing Fletcher's or Shakespeare's " chattering pies" or hearing this woodpecker's tumultuous, abandoned laughter, as though Nature leaped like David before the Ark and shouted for joy, the day for me was a dies non, and this sight and this sound have ever remained to me the first in favour above all others which large birds can give. We can see him or rather hear him too from the other end of the tale, for there are times when he suspends his song half-way to the end, and there is a certain resemblance to the loud double chirp of the greater spotted woodpecker, itself perhaps close to the original call-note of the woodpecker family, from which springs the beautiful, proud voice of our bird.

It is strange to think that the world of animate nature was once "dumb" indeed. The Labyrinthodonts of the Permian period must have achieved their great conquest of the land without any shout of triumphhave mated silently, grappled silently and died silently. What amphibian was it that first used language and startled a speechless world with the first grunt or roar ever heard? He anticipated Shakespeare. Witchell in his remarkable and unjustly neglected Evolution of BirdSong suggests that the first articulations of birds were produced by the excitement of fighting, which agitated their lungs. But it is just as likely that they were produced by the excitements of sexual impulse, that they were call-notes rather than alarm or battle-cries, the alarm-cry possibly being a variant of the call-note, which was seized upon by sexual selection, and gradually differentiated and elaborated like plumage and display. 


\section{A DORSET DIARY}

Witchell suggests ingeniously that it has been want of leisure which has prevented the development of song among tropical species-leisure being indispensable to varied singing and temperate species having fewer natural enemies. It seems a little fanciful, for tropical species have plenty of time to be absorbed in nuptial dance, and hawks are of world-wide distribution. Bright plumage is the song of the tropical bird. At any rate the alarm cry has remained less differentiated than the call-note from which, first by repetition (as occurs in simpler songs) and then by changes of pitch, tone, pause, etc., song as we know it, has been evolved. So to listen first to the call-note and then the song of the nightingale is a shorthand of evolution. The world did not begin with the roseate spoonbill and the bird of paradise, nor the thrush's maternal devotion, nor the symmetry of the tiger burning bright in the forests of the night, nor the swiftness of the hare nor the curves of the antelope. They have been achieved in their perfection by the enthusiasm and industry of countless experiments, by elaboration from the dust of substance, by fugues wrung out of croaks, wings out of scales, beating hearts, warm blood and softest down out of gelatine, even as we have conjured the Dryad of flame out of petrified timber.

Green woodpeckers are called "yaffles" in Dorset, but their fine old name of "yappingale" is lost with the wellnigh vanished Dorset dialect. For the Dorset folk cannot understand their own dialect poet, William Barnes, as I have repeatedly proved. Other names, now vanished, for the green woodpecker were "rainbird," "hewel" (hewhole-Andrew Marvell) and "woodwale." The latter occurs in Chaucer's translation of the "Roman de la Rose," and both original and version are so beautiful that I am tempted to give them both:-

II étoit tout couvert d'oisiaulx

De rossignols et de papagaux

De calendre et de mesangel.

II semblait que ce fut une angel

Qui fuz tout droit venuz du ciel. 


\section{BIRDS OF THE COUNTRYSIDE}

Chaucer's paraphrase is as follows :-

But nightingales, a full great rout

That flien over his head about,

The leaves felden as they flien,

And he was all with birds wien,

With popinjay, with nightingale,

With chelaundre and with wodewale,

With finch, with lark, and with archangel.

He seemed as he were an angell,

That down were comen from Heaven clear.

What the chelaundre is I know not. According to Ruskin (a very doubtful authority) " mesangel " (Anglicé, archangel) is a provincialism from $\mu \epsilon \hat{\imath} 0 \nu$-viz. smallest, viz. a titmouse. But why not a goldcrest, then, or a wren?

October 28th.-I walked out into the wildest parts of the hills. The country gets more desolate in this direction, and there are some fine prospects, or rather lines and slopes, for this part of Dorset is nearly all form and no colour. I came across a bloodthirsty weasel, dragging a large buck rabbit after it. The little savage would only leave its prey when I was hard upon it, and then only lopped off reluctantly for a few yards. I am not sure that one cannot discover the presence of evil in the weasel, so rare in nature. For killing out of blood-lust (as the weasel does) and not for food is surely evil as indeed it is useless. There is no need to be too anthropomorphic or to apply the standards of a higher stratum of evolution to those of a lower. What is "evil" in the vertebrate animal may be "good" in the mollusc. The truth of the matter is in Lecky's saying that an individual or nation which falls below the ethical standards of his or its own time is more immoral than an individual or nation of a lower grade which keeps pace with those of his or its own time, even though absolutely the action of the latter is morally much worse than that of the former. Degeneration is a relative term, and we justly call the cuckoo and the weasel "evil" because their average conduct is inferior to that of their avian and mammalian congeners. But it is a highly complex 


\section{A DORSET DIARY}

problem, and I forbear to penetrate it except to suggest that if nature be quite perfect, the absorbing interest of evolution, that gradual infiltration of the spirit into matter is destroyed and the future mortgaged. Our joy in nature is born not only of her exceeding beauty, but of that very imperfection which prescribes conflict and glorifies its end.

Assuredly, if we find mental, emotional and æsthetic qualities in animals - and mind is no more a monopoly of man than beauty-we occasionally find their correlative, evil, the prerogative, in a complex form, of man. ${ }^{1}$

November $2 n d$. - The sea was running high and fast to-day in bright, glad, highly-strung weather (like Alexander Smith's day, strayed from its April home) and riding and cresting the great curling waves was a mass of herring gulls, partly on and partly above the breakers, so that gulls and waves seemed of one substance, in a relationship by which their separate identities wavered and were exchanged. It was a sudden apparition of the materialized spirit of wild freedom. On the shingle, pied wagtails were running and singing, so blended with the greys and high lights of the stones that it was difficult to distinguish them. I notice that the wren now often breaks off his period short of the trill. But the quality of the voice after the autumn moult was very pure and sweet. The winter climate here is so mild this year that lambs are daily being born and are abroad with their mothers well into the dusk.

November 3rd.-In spite of the open country, larks are rare here-both in summer and winter. It was quite an event to meet with a small band of them. Gluttony and "economic ornithology" are doing the trick. The folly of the utilitarian spirit lately abroad runs its ugliness very close. I remember passing some allotments in the summer-the district shall be name-

1 See Romanes' [Mental Evolution of Animals] list of the emotions of animals. The psychology of animals is also discussed by Tyler, Simpson, Thomson, Drummond, Gamble, Julian Huxley, Lloyd Morgan, and other philosophic biologists, not to mention the suggestive correspondence columns of the Spectator. 
less for the credit of its people-sown with potatoes alone. Blackbirds and thrushes (whose exasperating beaks were specially modified to serve as spades the moment Sir Walter Raleigh landed on our shores with a potato tuber in his pocket) were hanging half-decomposed from wires fastened to poles stuck in the ground. How much less silent are these winter months than were August and July! We hear not the bird's songs, but their conversation.

November 4 th.-Up in the hills I saw a solitary siskin, in company with cole-tits, and a few yards further on, three goldfinches sitting on a dogrose-spray in the hedge. How pleasant to think that I owe the sight of this feathered cherub to the efforts of Mr. W. H. Hudson! We do not see them, alas! in their tens of thousands, as Cobbett used to do. But some years ago they were nearly extinct in Dorset, and Mr. Hudson relates that he tramped fifty miles of Dorset soil without seeing one. Now that the bird-catcher has been slightly checked from depopulating England of its loveliest small birds, the goldfinches are a little on the increase. I have seen them in half a dozen different places within a circuit of four miles, on the cliffs, in orchards, on the uplands, and actually in the village itself-sometimes in flocks of from six to a dozen.

November 9th.-To-day I saw a sparrow-hawk hovering (they do hover, though less obviously than the kestrel) right over the farm-house where I am staying. ${ }^{1}$

I spent some time in the cider orchard adjoining the northern outpost of my village and saw never a bird. In the early summer it was a birds' club and, like ancient Athenians and modern art circles, I was always running after some new thing in it. A thick sprawling hedge surrounded it, bulging inside with bramble and pierced at intervals by tall elms. The

1 I regret the scarcity of hawks not only for their own sake and my pleasure in seeing them, but because they keep their prey in health and vitality, by picking off the weaklings in the one and the laggards in the other, because their removal upsets the poise of life and because it shows modern man to be a wanton fool. 
ground, all waving with feathery grasses, tilted gently down to a narrow stream or ditch crowded in with pollard willows, alders and more bramble and fields spread widely out from its old and lichened apple-trees on three sides; so that it was a well-chosen site for a Parliament of Foules. Hither came regularly all three woodpeckers, the greater spotted most of all. I once crept to within a few inches of him when he was probing an apple-tree bark on the further side of me, and we both popped our heads over the gap where it forked into branches at one and the same moment. My visd-vis was paralysed with astonishment, and for about five seconds he gaped at me as I at his white cheeks and forehead, black crown and scarlet nape, before he sped away, winding among the boles with loud exclamations of alarm. The lesser spotted or "barred" woodpecker usually kept to the tops of the elms, but he once perched among the branches of an overturned tree on whose root I was sitting, a duodecimo edition in his barred plumage of the chequered sunlight entangled in the dark matted twigs. Hither, too, came the lovely diamonded wryneck, announcing his presence by his thrice-repeated peal and striking terror perhaps into the ants clustering the lichened boles. I saw him every day for a week, and I vow he got used to me. Then he disappeared and I never saw him more. For how many years longer will English orchards shelter the " cuckoo's boder," a romantic bird gradually failing us and so doomed in the future to end his days in a glass case? Here, too, stridulated the grasshopper warbler; small breakdown gangs of goldfinches used to float the tree-tops like motes of sun and set to work to clear the thistle-heads by the stream; a sparrowhawk occasionally policed the hedges and a butcherbird appeared now and again, though his pitch was elsewhere. High in the greenery of one of the elms a wood-wren quartered himself for some time, and I used to make a point of sitting at its foot in the evening to hear his leafy song, preluded by bright strokes-chit, chit, chit, chit-running with beautiful abandon into a quavering trill, as he shivered his long, bright wings. 
Why he (a wanderer and a lover of beech and oak) selected this elm rather than the others I do not know, but so it was. Not far from it on the further side of the stream, where had grown fairy windflowers and bluebells "at whose birth the sod scarce heaved," all air, all hue, immaterial like the sigh of spring, there in the meadow, I had flushed a corncrake and actually put that wedge-shaped body to flight, the only corncrake I have seen for two years. ${ }^{1}$ Here, too, the elegant nuthatch came to disport himself and point and curvet among the boles to the song of the blackcap and owls and jays used to take it en voyage. The back-benchers were in strong force, and oxeye, creeper, greenfinch, chaffinch, throstle, blackbird and wren nested herein or close by. Only two reared a family. But now this storied orchard was utterly deserted. Nor was it really curious, for one of the unwritten laws of autumnal bird movements is to take to the open.

November 12th. - The fieldfares have come at last, and I would meet them rushing overhead with their loud chack chack, or all facing one way both on the ground and in the trees, as though, as Vaughan says, " expecting some hidden matter."

I saw my redpoles again in the same place. They are a well-decorated little bird, of the titmouse shape and character, but of richer and deeper tints, the velvety maroon of the crown throwing up the warm mottlings of the back and subtly varying the rusty red (carmine in spring) of the breast and black of the chin, itself shading into a buffy white on the belly. One of the males sat conspicuously perched at the top of a vertical twig, almost motionless. Now he would dive down into the field to feed, and then resume his perch; now he would spring a dozen yards into the air, turn a kind of somersault, and descend again to the same perch. He never bothered himself about my near approach. We both enjoyed ourselves. The rooks, in spite of the dull day, were holding a committee meeting in the

1 The keeled sternum of the corncrake is, like that of the waterrail, specially adapted and narrowed to enable it to plough through the thick grass. 
rookery, debating (with some heckling and dissension) the pros and cons of repairing the dilapidations of their homes. The motion was finally thrown out, or at least referred to the Highways Sub-Committee, for presently they came trooping out with nothing done.

November 13th. - In a small cup-shaped depression of a large sloping grass field, fringed with a few reeds and with a little water in it (rather like a dewpondin the valley), I flushed a common snipe-much to my surprise, since, lonely as the country is, it is divided up among small farms and highly cultivated. The mottled bird zigzagged off so quickly that I could not have told it was not our winter visitor the jacksnipe, but for the fact that it sprang up with a strident, grating cry. I used to hear the snipe "drumming" or "bleating" every evening in the spring further north in the wilder country towards the Wiltshire border. A pair had nested in a bog starred with asphodel and sundew, and in the twilight the male's ghostly sport began, a diffused and mysterious sound like the twittering of Virgilian shades in Hades.

November 16th.-After watching half a dozen magpies flying and settling leisurely about a patch of the valley meadowland, I suddenly, while passing a thick hedge, ran my eyes straight against a smaller edition of them. It was a pied blackbird, a male with golden beak, black body, and wings pure snow-white (i.e. blue-white in shadow). He was a morsel cut out of the tropics, and very brilliant among the uniform greys and browns of his surroundings. I stood within a couple of feet of this fine creature. As I neared home a pied wagtail was disporting himself upon a thatched roof. How exhilarating are his sudden spasms of uncontrollable joy, when he leaps up into the air, or dashes with lowered head along in a run like a trill, and ends by frantically waving his tail! He positively cannot contain himself for the ecstasy of living, and I have often seen him literally tumble off a roof in glee, and only recover himself when near the ground. The ornithologists call him Motacilla lugubris.

The sun came shouldering out of a thick cloud as I 
reached home, so for me this was not so much a redletter as a pied day. It began with the black uppermost, for I found a shot crow lying in the fallows. There I buried him and placed a tombstone of clods at his head. Now that he has flown our many-coloured glass-house, perhaps he has reached "a place more rare," where God has granted his creatures a stronger sense of humour. It is interesting to note how kindred are the characters of magpie and pied wagtail.

November 17th. - The bullfinches have taken to the hedges, and to-day I had a sight of six of them. Nor was it a fugitive glimpse, as one expects with rare and persecuted birds. For these birds kept about twenty yards ahead of me for over a mile, flying in and out of the hedge and frequently allowing an approach of twelve feet. At one time I was so close to a female that I had only to stretch out my hand, had I desired to capture her. It is not surprising the bullfinch is rare; it is more so that he has not been extirpated. It has always been a pleasure to me that old Bewick defended the bullfinch's " disbudding" utility. "It is usefully busy," he also says, "in destroying the worms that are lodged in the tender buds." But gardeners live by bread alone, and so get nothing but half a loaf. Not that I care whether or no the bullfinch lives up to his reputation. But I know that self-interest does not look before and after, and that there is nothing in this world that brings so practical a well-being as reverence for beauty and respect for life. Even were it not so, and the universe a lie in consequence, are there many who would not give a few apples to see the bullfinch's rosy apple breast, blushing through the leaves-and not a core but a warm heart beating beneath it? For the bullfinch is part of the true glory of England, and in time will be exterminated by gardeners, bird-catchers, and the female savages who wear "wreaths" of them in their hats.

In my most careless days, the endangering of the life of a highly developed species, even if only out of this loved land of ours, seemed to me a sorry thing. Now in later years, when I have made some study of 


\section{A DORSET DIARY}

biology, which so illimitably expands the wonder and enhances the mystery of life, the extinction of a high species by the arbitrary action of man seems terrible to me. A species is "a sort of visible fugue wandering about a central theme," and to scratch out a beautiful note in it is irreparable. These gaily plumaged bullfinches of mine took short flights, were heavy on the wing, extremely conspicuous both at rest and in motion (the white rump being as plain to the sight in flight as that of the house-martin and greenshank), and not at all wary. Their alarm-cry, too-a low and gratefully melodious pipe-once heard, cannot fail to be recognized. They were feeding on the haws and the black currants of the wild madder, an abundant evergreen in patches in the south-west, and very conspicuous as it climbs among the naked twigs with its dark berries and whorls of glossy green leaves. That is your bullfinch. He goes about the world, like a wandering minstrel, making colour tunes.

November 20th.-In a spinney of mixed spindle and dogwood, with yews growing in it (I usually avoid woods, so empty are they of wild life), I believe I saw goldcrests, but I could not be sure, they were so high up. I would I had been, for the goldcrest was all but scratched off the list of the English avifauna in the winter of 1916-17.' I flushed a woodcock, the only one I have seen in this part of the country. The wren was singing mightily, and his song took on a kind of enchantment, almost a fantasy among the silent trees-not at all belonging to its normal, bright, busy, work-a-day quality. Thus do birds' songs differ, not only from individual to individual of the same species, but according to the mood of the day, the season of the year, and the character of the place in which they are sung. It is interesting to note how often a bird's song is the precise expression of the bird's temperament-robin, chaffinch, willow-warbler, wren, dunnock, blue-tit, sparrow, linnet, and yellow-hammer, for instance.

In Mr. Boraston's book (Birds by Land and Sea)

1 They are, however, recovering, and I have seen them in numbers since in different parts of the country. 


\section{BIRDS OF THE COUNTRYSIDE}

there is a discussion of the elaboration of song from the primitive call-note. 'The actual notes of a bird's song are no doubt an ancestral inheritance, but the quality of their composition depends upon the educability of the young birds, upon their power of profiting by the lessons of their parents. If the power of song was germinally transmitted from parent to offspring as completely as more automatic functions (the feeding specialization of a snipe or woodcock, for instance), we should not find, as we certainly do, great differences in musical quality between individuals of the same species. The call-note, on the other hand, is vastly more uniform, far less susceptible to individual modification, and a much truer indication of family relationships and common descent from general types. The alarm, recognition and call-notes are a racial entail; the song individual and acquired through filial imitation in successive generations.

All evolution has been won out of some kind of individual effort and free will, and every nestling must learn the melody that the character of its parents has wrested for it out of the uniform backward of time. So it is in art, and every fine poem, statue and symphony repeats in little the story of evolution, while anticipating its climax. The difference between a bird's call-note and its song is the same difference as that between writing and literature.

I am wrong about the colour of Dorset. On a fine day like this the bare shoulders of land are suffused, or rather blushed, with a peculiar, ethereal, delicate pearl. Pink, blue and lavender are all in pearl, but the greens and browns seem to distil into this gauzelike lustre as well. If one stands upon one of these shoulders and looks across the chequered fields to the low-lying purple ranges of hills beyond and other amethystine ranges beyond them, all in half-tones, then the true inwardness of this part of Dorset is rather intensified than lost. For one views the glories of its setting, as a man putting his hand to some close detail of craftsmanship will see it give sudden form to the 1 See above. 
whole traceried design, behind which glow the meaning and perspective of all the universe. But the eye travels by chance upon a clump of beech from whose dark filigreed twigs dangle a few late leaves of beaten gold - and the setting fades before this new and intimate enchantment. I notice that the tits in this mild winter climate are as often to be seen in pairs as communities.

November 25th.-Up in the hills I came out of a lane into the open pasture. A crow started up at my feet and pelted away, shouting out at the top of his voice-" Look out, look out, here comes one of those murderous human louts!" Two redwings (I have seen very few of them this winter) dashed away in an abandonment of terror with a wild irregular flight; a small flock of pipits sprang aloft with squeaks of dismay; a throstle plunged into the undergrowth of the hedge; three wood-pigeons left their tree and fanned the air with the speed of the wind; and a magpie, floating amiably along, hurled himself headlong to the earth, to put the slope between him and me. Such is the welcome accorded to the human form divine. As men pursue happiness, so bird-lovers the birds, and with the same results. For it is ourselves who are the outcasts of nature, not the crow and the pie. Our sovereign capacity so misused has made us foreigners upon this green earth.

December 2nd.-I met a rarish bird to-day, the shorteared owl, out at about three o'clock in the afternoon, and hunting formally and silently close to the ground, like a small feathered greyhound. On the hill I found a victim of the sparrow-hawk, a male blackbird, with but the golden mandibles and a pile of feathers for the epitaph of Colin and his flute, who will sing no more madrigals to his Chloe what time the "sweet militia" of flowers begins once more to march along the vale. It was a Cimmerian day, and the birds passed through the mirk, like shadows of themselves. I made out a couple of nuthatches on one of the rookery elms. There is something very distinguished about the nuthatch, and his beautifully disposed and harmonized colouring and sprightly, independent, varied movements and 


\section{BIRDS OF THE COUNTRYSIDE}

attitudes about the bark made him a charming picture. These birds had a way of diving headlong with furled wings from a higher to a lower branch, dropping like a stone through the air and alighting with the utmost grace and ease. What a plodder the tree-creeper is beside them! The rooks were shouting away by their nests, bowing their heads, spread-eagling their tails, flying, floating and scrambling in a ferment of excitement. Repairing operations had begun, and I must have been mistaken about the vote. Little did those ingenuous, trusting rooks know that the housing question was not to be settled for many a grey and blustering day.

December $3 r d$. - I set out, and within a hundred yards blundered through the Looking-Glass. On the roof of a cow-byre a wagtail minced, pranced and twirled, while the mate flung himself or herself through space like some airy, miniature dolphin of a rarer element than its own. Blue, cole and great tits shone skyblue, grey, buff and black against the dark gloss of ivy-draped thorns and hollies. In the tree above my head a bullfinch dipped his old-rose-red breast, bowed his lustrous black head and tilted his blue-grey back over some "daintie dish" invisible to me. Blackbirds chuckled in the hedge; sparrows and chaffinches poked out their chests on the hawthorns; a nuthatch pried about the bark of an ash near by; robin was in fullest song, sprinkling coloured jets of sound into the still, grey atmosphere; and a roving band of fieldfares took the sky with powerful wings overhead. One tells it all in plodding sequence, but it happened simultaneously and vanished with the breath of pleasure one spent upon it.

Thence I wandered into the fields and watched the tits, sparrows, finches and buntings, feeding from the remains of a corn-stack. There were four yellow-hammers and a pair of corn-buntings on a small ash five yards away, and the brilliant yellows of the hammers shone and glowed against the neutral tints of earth and sky. It is when we get close to our native birds that we realize that their sober sheen is an illusion of distance. 


\section{A DORSET DIARY}

The colouring of a large number of our species is quite radiant after their honest English fashion.

The great tit (also brilliant in his way) will always get on in the world. He seems quite indeterminate in his way of living, feeding on the ground like a finch, in the trees like a tit, in the air like a fly-catcher, hammering the bark like a creeper, and equally at home in every calling.

From this incalculable, indeterminate method of getting his living, may we not assume that his species is potentially more capable of variation than other more highly specialized types? The great tit, like the sparrow, is in the mid-stream of evolution; he is in the full current of progress; he has a future before him. I will not attempt to go into the highly complex problems of the causes and conditions of variation, of the gradual (or sudden as sometimes happens) metamorphosis of one species into another and usually higher (as the history of the world shows) type. But one may say with some confidence that the inventions or qualities which have contributed more to the "differentiation and integration" of life as it is at present than any other have been the following: Increased mobility (only very few of the heavily armoured types have survived in smaller descendants confined within narrow areas); the development of parental care (the seedbearing plants of the secondary period quite ousted the spore-bearers); the power of combining for mutual aid (the vast majority of modern vertebrates are social); the growth of the brain and the nervous system (there is an enormous difference between the brains of modern mammals and the marsupials and monotremes of the secondary period); the indomitable will to live and all-roundness, by which I mean the avoidance of overspecialization. The gorilla cannot progress because it is over-specialized. This last was the great point of Samuel Butler, who so well called mutations "happy thoughts," and compared evolution with the development of a fugue from a very simple subject. The Admirable Crichtons have been the founders of great houses and the heirs of the ages, and nature is against 


\section{BIRDS OF THE COUNTRYSIDE}

the expert who loses touch with the whole in his knowledge of the part. "It is possible," write Geddes and Thomson,

to interpret ideals of ethical progress-through love and sociability, co-operation and sacrifice-not as mere Utopias contradicted by experience, but as the highest expressions of the central evolutionary process of the natural world. As evolutionary biologists we are thus practically with moralist and theologian, even with poet and sentimentalist, if you will, against the "vulgar economist" of Ruskin or the self-styled practical politician of to-day.

Or we can put it in another way, and say with the all-round man against the specialist, with the trinity of knowing, feeling and doing, with the good, the true and the beautiful against the dominance of one or other to the exclusion of the rest. Well, the great tit is in his small way an all-rounder, as the wryneck, for instance, is not.

December 5th.-A day of small things but large birds. Four and forty rooks all perched motionless on a small leafless ash presented a sufficiently droll and fantastic design. A magpie and a jay were sitting comfortably together on the same twig, and as soon as my abhorred form loomed up, the magpie scuttled away across the open field, but the jay dropped down on the further side of the hedge and crept away invisibly along it. Ah, friend, thought I of him, you will take some stamping out! Pipits keep open house, for I find their assemblies constantly mingled with larks, finches, buntings and wagtails in the fields. I saw a detachment from this League of Feathered Nations to-day fly up into an elm where a kestrel was taking his ease. They took no notice of him at all as he of them, not even to harry him. The kestrel as a rule has much ado to keep his dignity, so pestered is he by nearly every bird that flies. As for retaliating, he never dreams of it, and were it not for his accipitrine turn-out, birds would no more regard him than they do a heron. Small deer, not small birds are his concern. ${ }^{1}$

1 By nature, that is to say. In game-preserving districts the kestrel often becomes a bird-eater, the temptation of being sur- 


\section{A DORSET DIARY}

December 8th.-With the sun full shining, billowy clouds edged with pearl, catkins in the hedges, campions in the banks, daisies and knapweed in the fields, a few primroses, "sweet infantas of the year," in sheltered spots, and flaming patches of gorse, with robins holding rival concerts, and the wren chanting the pleasures of labour, it was easy to say, "If winter comes, can spring be far behind ?" The primroses had come peering from their windows of mould out of curiosity to hear the bleating of the lambs, and lo, it was spring! So they remained, leaning out of their window-sills, enjoying the zephyrine air they breathed, when they ought to have been inside, reading and taking to heart a poem called, "On an Infant, Dying as soon as Born." Surely that bleating should have warned them! I, too, began to feel my sap rising until I happened to turn my head to see a couple of robins grappling on the ground five yards away. Their wings frantically beat the sod and they were closed like wrestlers, positively rolling over and over right to my feet. Finally, one extricated himself and took off, the other champion pelting after him. Who was the victor, older or younger generation? At any rate, I know where to find one sovereign robin, princeling of his little state. I have seen robins fighting desperately scores of times, but never to the death, and I believe that the mortal combat is very uncommon, as it is among other birds, who fight like mad at mating-time, with an occasional loss of a feather or too. But I knew now it was not spring.

Pheasants were numerous, and I watched the rooks standing two and three at a time on the cows' backs, ridding them of ticks (an example, like that of starlings and sheep, of "commensalism" in England), while others were tackling the mole-heaps and using their beaks like spades to shovel aside the earth. Curiously enough, I flushed a jack-snipe in the same small, marshy depression where I had previously put up a common snipe. It is a smaller bird, with a less sustained rounded by pheasant chicks being too much for him. He acquires the taste, and then becomes more destructive to wild small birds than the sparrow-hawk. 


\section{BIRDS OF THE COUNTRYSIDE}

flight, and less mastery in the May-fly art of flight, and utters no alarm-cry when roused, as the common snipe always does. ${ }^{1}$ I was standing watching a robin singing, when a wren came bustling out of a hedge six inches from my head. Suddenly catching sight of me, he bounced up on a prominent twig and roundly abused me for disturbing his honest toil. I sneaked off. The small birds, thanks to the warmth and moist and open weather, are very plump and well-conditioned-many of them quite portly.

December 10th.-Another fine day and a walk down to the sea, which, just before sunset, was of a very subtle colouring-in three layers, bottom slate-grey, middle a pale, cold, delicate blue, and top powdered over with gold dust. It was soon over, but magical, prophetic while it lasted. It is not strange that an ancient people looked upon the rainbow as the symbol of a promise, for all natural displays out of the common round are somehow annunciations. On the way down I saw a pair of jays scolding a tawny owl, which retaliated with vigour. On the way back it grew dusk, and, as I descended a hill, the vale suddenly burst into song until it was "overflowing with the sound." The dunnock struck up his trivial, shrill, small strain, the wren was in fine voice, robins improvised and (best of all) a throstle on an ash was giving a full serviceloud, brilliant, varied, harsh and dulcet at the same time. He is never a fine singer-his merit is his luxuriance, copiousness, experimentalism and rich gladness. But on this December day he seemed a spirit, and in keenest sympathy with the human mind. I thought of spring, and his melody said :-

We look before and after, And sigh for what is not.

2 That fine observer, T. A. Coward, says that "its call, if uttered, is not so loud," when the bird is flushed. I can hardly disagree with him. All I can say is that in my experience, and I have often flushed the jack-snipe in East Anglia, I have never heard him utter a sound. 


\section{A DORSET DIARY}

I thought of him as that intangible desire for which we look and sigh.

Witchell declares that the perceptible difference between matins and evensong in bird music is due to the operation of different influences. In the morning birds sing the pleasures of anticipation, in the evening from leisure and the sense of a good day's work accomplished. May we not go even further and discover in these emotional differences a subtle adaptation to the atmospheric conditions? The spring song of the robin is glad, the autumn song subdued and melancholy, and this change is a reality, and not simply due to a hypertrophied fancy on our part which interprets the robin's two songs by the time of the year in which he sings them. Nature is nearly all fitness and harmony; her creatures are a pattern of adaptations. The voice of the buzzard is adapted to the wildness and solitude of his haunts : why should not the morning and evening songs of birds be adapted to the exultation of the one and the repose of the other? There may even be a physiological change in the metabolism of the body, just as when Wordsworth wrote "my heart leaps up when I behold". he wrote as a good physicist as well as a good poet. His body actually did echo his emotion.

I noticed that several blackbirds were perched about this thrush, attempting to sing, but only producing a metallic sound, something like that of a spoon striking the inside of a cup, but not quite so dull. Is it an untenable hypothesis that blackbirds do actually lose their voices in the winter? Here, at any rate, were favourable conditions-dusk, a warm day, the example of other birds, their own attitude and, as it appeared, desire to sing. By the village church a barn-owl was floating silently, low down almost at the roots of the apple-trees in an orchard.

Nor was I at the end of the repertory of song, for starlings were carrying through their astonishing performance on the vane of the church tower, and if the honest starling is not pre-cminent for quality, he carries off the palm for variety. I think he is a mocker, for I have often heard him imitating bird-notes, especially 
the sharp call-note of the chaffinch, the family calls of the tits, a syllable or two from the yellow-hammer's reedy epigram, and various notes from the repertory of blackbird and throstle.

$\mathrm{He}$ also imitates his brethren, and this conscious and social mimicry may be the prelude in the future to deliberate chorus singing, two actual examples of which, I believe, have been recorded. The crested screamer of the pampas of La Plata (see Hudson) undoubtedly did so sing in orderly pause and rhythmic unison.

But like the jay, and unlike the marsh warbler, the starling is an ambitious amateur, and his naive echoes of the feathered poets are usually not more than plausible. I doubt whether he imitates other bird-songs for any other reason than to add to his inexhaustible larder of expression. Some observers have attempted to disentangle the various objects from the sounds representing them. Such naturalism is not for me. When a band of performing starlings is congregated, I remember Walter Crane's atrocious wood-engraving of "The Triumph of Labour," and at once the procession starts. The tabors are sounded, the cymbals crash, women kiss their babes with resounding smacks, the cartwheels crunch over the ground, and the harness of the oxen creaks in a joyful medley of sound.

December 11th. - I came upon about thirty redwings to-day, volleying loud cries in a large holly, occasionally raising their wings to display the deep chestnut of the flanks and under wing-coverts and softening their notes on taking flight. The "feltie" is a hardy bird, and so little of an epicure in his diet that he can stand our winters with the best of them. But the delicate and fastidious redwing, how is it that he does not migrate further south when he leaves his northern pines, or for that matter leaves us when the sun comes our way once more ? He is the smallest of the British thrushes, and though such a Northerner, the frailest (he does feed on berries because I have seen him do so). In severe weather, consequently, it goes very hard with him. Certainly, his ways are not the least of the mysteries of migration. It may be that he migrated to England 


\section{A DORSET DIARY}

when it was part of the tropical belt, and has failed so far to adapt his constitution to the changed conditions. In the same way it seems to me possible that the nightingale fails to cross his limited area of the Home Counties, because its borders at one time were that of the ice zone. It is easy to distinguish redwing from song-thrush, not only by the orange-chestnut of the flanks, but the white eye-stripe.

In a cowyard filled with muddy water I had a good sight of a mistle-thrush, a bullfinch and a pair of grey wagtails. The bullfinch against the dark mud and the sodden leaves was sumptuous, Oriental, a small ambassador to us islanders from Araby or the Spice Islands. A wonderful mean has been struck between harmony and contrast in the colouring, so right and yet so audacious.

December 13th.-I saw seven bullfinches to-day, and these fairy lamps (burly in form though they be) seemed to light up the grey winter day. As I stood under an elm in the hedgerow a great cry burst out of the dark air, and sweeping out of it with closed wings came the yaffle upon the bark-becoming instantly motionless, with body and head pressed back from the trunk, so that he looked like a statue cut out of jade. Then he looked down waggishly at me, and away he went into the murk with that rushing, soaring and dipping flight of his like sudden breaths. Still standing, I was passed by two assemblies of tits, like a company of mediæval mummers going the rounds, or a gang of labourers in some minute and perfect state. Climbing the hill, a covey of partridges shot away from me with rapid wing-beats, and a moment later an immense flock of gulls and rooks came up the sky from the pastures and began wheeling in and out, backwards and forwards through each other's ranks. It was a pied cloud drifting the lower ether. In a desolate part of the hills I encountered a single marsh-tit, thus for once in a way justifying his reputation as a wanderer in solitary places. Descending into the valley again, I made out siskins (a beautiful composite of yellow, black, grey, green and white even in the dulled winter 


\section{BIRDS OF THE COUNTRYSIDE}

dress) perched on the branch of a small ash among a flock of forty or so chaffinches, and not six yards from where I crouched. It is not often that the siskin's roof is the sky, his bars the wide horizon, his floor the earth, and his box of seeds the verdure thereof, rot often that (like the great tit) he associates with chaffinches-tits, goldcrests and redpoles being his usual companions.

December 15th.-The day was the darkest yet for my farewell ramble. I watched a biggish bird on an elm darting up and down from branch to branch, wagging his head, scuffling to and fro in a fever of restlessness, and uttering an extraordinary cry like that of a dog on a chain-half bark, half whine. Naturally, this was exciting, and I stalked this oddity as well as I could, now that the land is all bog. Then, before I could get very close, away he flew, displaying the white rump and discharging the characteristic scream of the jay. But I have never heard the jay imitating a yard-dog before, nor seen any account of it in a natural history volume. Was he actually mocking a dog he had heard ? Montagu in his Dictionary of Birds says the jay will at intervals introduce into its spring song "the bleatings of a Lamb, mewing of a Cat, the note of a Kite or Buzzard, hooting of an Owl, and even the neighing of a Horse."

Mimicry, indeed, plays a much larger part in birdlife than is supposed. In captivity, when the poor things have little else to do, most birds imitate the sounds they hear about them, and in London I have heard a song thrush imitate the loud yell of a parrot in a house near his evening perch to perfection. There are numerous examples of blackbirds picking up the bar of some popular song, and the young of the finer singers learn their parents' melodies by intelligent mimicry, grafted on to fundamental inheritance. Witchell gives many examples (a trifle stretched, it is true) of birds imitating elemental sounds-onomatopœia in fact-the belted kingfisher a mill-dam, owls the moaning of wind in hollow trees, the American marsh-wren the air-bubbles of the marsh, and other birds the rippling of streams. 
I have heard a starling imitate the pee rwit of the lapwing, and it is recorded of another starling that he used to imitate the chapel-bell, swinging his body to and fro in the manner of the bell's pendulum the while. It is perhaps too soon to state definitely (as Witchell does) that songs and cries are modulated to resemble sounds with which the birds are familiar, but it is a striking fact that the voices of birds are as much in harmony with the sounds of their neighbourhood as their colours with those of their surroundings, and this may be at any rate partly due to conscious mimicry. I profess myself willing to believe anything after reading Henry Drummond's account in Tropical Africa of an insect instinctively imitating a bird dropping. Of one thing we may be sure-nature's sound artistic taste is at the back of it all.

One thing the vocal imitations of birds do provetheir acute awareness and intelligent appreciation of what goes on around them on the one hand and their ingrained social sensibilities on the other. The following is R. W. Schufeldt's description of an American mockingbird (Mimus poliglottus) :-

Clearly and with the greatest possible accuracy and rapidity, and with a mellow strength even exceeding the originals, he utters the notes and calls of twenty or more birds in succession, ranging all the way from the plaintive air of the bluebird to the harsh, discordant cries of jays, sparrow-hawks, and even with equal compass the vociferations of the eagle. Catching breath, and tossing himself lightly into the air above his perch, he alarms the entire feathered community assembled by his imitating the cries of a birdling seized by a hawk; this is followed, perhaps, by the crowing of a cock or the vociferous note of the whippoorwill, and the very incongruity appears to put his feathered listeners to shame at the hoax.

The passage surely gathers up a bundle of social realizations-curiosity, perception, humour, pride, memory, æsthetic pleasure and conscious make-believe elaborated into deliberate social drama. The whole scene is bathed in a consciousness of which the simpler mimetic faculty is the raw material. A performance like this is to the first lispings of the young bird conning his parent's 


\section{BIRDS OF THE COUNTRYSIDE}

song what Burbidge, Garrick and Mrs. Siddons are to the rustic mime capering about in a country manor house with a bear's head over his own.

I may at any rate add to Montague's description of the vocal accomplishments of the jay "the bark and whine of a Dog," and remember it for an antiquarian curiosity when those "imperfectly acquainted with the ways of Nature," as that good scholar of nature, Professor Newton, says, have won their gallant war and brought the last effervescent jay in his cobalt blue, cinnamon, jetty black and snow white livery down dead at their feet.

Returning home I heard the sound that to me is the most sovereign of all the repertory of our larger English birds-the inexpressibly joyous, clear, wild, free and intense laugh of the yaffle. Upon a memory so bright and void of care it is well to close. 


\section{CHAPTER VII}

\section{A VILLAGE IN HAMPSHIRE}

I

D. McTAGGART, in an essay on immortality, maintained that the mind is a kind of natural sieve. When we set out from the terminus of this world at the end of our lives, we retain or ought to retain as our luggage only the true essentials of our individual knowledge and experience. They are our ticket as well as our luggage, and will carry us into a country of new knowledge and new experience just so far as our booking allows. Not being the authority on future worlds, which many others claim to be nowadays, I do not pretend to apply the simile to any other worlds but this one, and more narrowly in this chapter to that particular North Hampshire village which I have visited many times in spring, summer and autumn.

I remember a casual remark of Mr. Hudson's to the effect that unless birds are seen emotionally, the mental image of them cannot be retained. Thus, when we see birds at their very best, our emotions respond to them the more eagerly, and the image we carry away is the more vividly stamped. These investments of the backward-looking mind among the most solid securities - solid because they are the most enduring, and the most enduring because certain selected circumstances have been unusually favourable to them-remain as sound and bright as heretofore, as others have been (to mix metaphors) moulted off. I shall write this chapter, then, upon the theme of "birds at their best." "

1 Birds, of course, are usually at their best-physiological as well as mental and æsthetic-in the spring, with its nuptial flights and dances, its devotion and parental care, and so on. But I am taking a more personal point of view. 
That is no reflection on the country. The part of Hampshire where my village lies is graced with a rich fertility, a plumpness comfortable without distinction. It shows its second best in the flowers and its third in the hangars or ranges of hills whose slopes are thickly plumed with woods (mostly beech) and extend for miles, dropping gently down at intervals into the broad valleys lavishly spread with crops, pastures, plantations and barbed wire. But even these hangars are a trifle monotonous unless one can look down on a clear day from a height upon the autumnal foliage, quilted with patches of red, gold, russet, sage green of a clump of conifers, yellow, purple at a distance, and brown, like a dome of many-coloured glass staining the wide, uniform heavens.

My acquaintance with flowers is unhappily not apace with my friendship for them, for it is my wild ambition to know every species of British plant and animal from diatom and infusorian upwards-the desire of the moth for the star. But even I can tell that the soils of Hampshire have a particular kindness for plants, and the luxuriance of the summer and autumn hedges is quite tropical, especially that of the plume-flowered Traveller's Joy (named by old Gerarde), whose powerful runners surge over their tops, mingled among the delicate patterns and designs of the purple tufted vetch, with woodbine, honeysuckle, the greenish blossoms of white briony and the scarlet grapes of the black, dessert for autumn birds-which, luckily for them, we cannot eat-some of whose leaves are green and others a rich copper. Hemp agrimony also telescopes the seasons in this way with its clusters of crimson buds and misty flowers together, and for a mingling of colours in the shadows and borders of the hedges there are hemp-nettle with its whorls of pink flowers, the orange berries of wake robin, the greenish-yellow spikes of wood sage, red and white campion, forget-me-not, woody nightshade, purple wood betony, slender agrimony (a great favourite of mine), the thin candelabra of the once sacred lilac vervain, smooth, rosy centaury (which shuts at noon and points its fingers to the sky), yellow bedstraw, mallow as delicate as the wild rose, the 


\section{A VILLAGE IN HAMPSHIRE}

reddish spikes of sorrel, scabious-and many others, a catalogue as endless as that of the Catholic saints.

The fields, too, have their pennies out of the pocket of millionaire nature. Purple loosestrife with pennons that look like foxglove at a distance is very abundant in damp places, dominating the meadow-sweet, the flesh-coloured flowers of gipsy-wort and the glossy leaves, handsome, single, yellow flowers and graceful, weeping stems of herb twopence or penny-wort, its humbler cousin, and like the creeping jenny of gardens. On the edges both of grass and cornfields the roseate restharrow makes quite a bushy undergrowth, and beside it stands the bold burdock with its wavy leaves, hooked scales and decorative purple heads, while the pimpernel in the thinner patches of the corn is so plentiful as to stain the ground with a reddish dye, the masses of crimson and lilac majoram running yet other hues into the quilt. In an upland pasture, strewn with the purplish-green leaves and pink flowers of red bartsia, I found two toadflaxes flowering side by side, the commoner yellow with straight spurs in the hedge and the round-leaved (whose spurs are curled) with single flowers growing out of each axil. And not less beautiful, if coarser in effect, are the vivid, scattered flares of the ragwort, dimming the pale, gold buttons of the aromatic tansy at its elbow.

But the finer flowers grow on the chalk slopes among the thyme and eyebright, splashed with the purest of yellows. Here the little milkwort, azure, but sometimes pink and sometimes white, and looking doubleflowered owing to the long petal-like sepals being coloured like the flower, is quite common, as is vipers bugloss over small areas with its cobalt hues, varied here and there with flowers of a bright rose. The three gentians grew in company here like the Three Graces, gentianella at the end of an attenuated stalk a few inches high, the field gentian and the autumnal gentian, whose flower is of a lighter purple. Among his hellebores, ladies' tresses, etc., which Gilbert White mentions as growing upon Selborne Common (some of which extend their range to these slopes), is the curious per- 
foliate yellow wort with erect stem, thrust through the glaucous, up-curled leaves.

But flowers are birds and butterflies that cannot fly. Nature cannot be at her best without the birds, and the most splendid and moving portraits of her in verse and prose are lacking, unless they take account of the whole rather than the less animate piece. I have wandered in places where nature, unlike the young man in the Scriptures, seemed to give all that she had. But all she did not give, for birds were few-rari nantes in gurgite vasto - and their absence crippled her beauty.

I remember walking along some water-meadows one day near my village, "enamelled o'er" with a press of flowers dropped like rain out of nature's seed-box, and finding it empty of voice and flying shape. Without the birds, it was a melancholy still life picture; or a house with bright curtains in the open windows, cushions in the chairs, table laid and door set wide, inviting dwellers that come not; or the blue sky in the Ancient Mariner, a sky wherein the stars do not enter "as lords that are certainly expected." For the birds are nature's articulation, and without them she is a sleeping princess, a tree in winter, fine clothes in a window, with no fair body to wear them. What rhythm is to the poet, so birds to nature.

I remember another occasion one early spring morning about half-past five when I was awakened to the first feathered chorus I had heard that year. Chaffinch, blackbird, throstle, blue and great tits, wren, robin and dunnock could be disentangled from these wild matins to the morning of the year. But it was idle thus splitting and labelling the whole-a festival, turning the world into a dew-drop of song:-

Glorious the sun in mid career;

Glorious th' assembled fires appear ;

Glorious the comet's train :

Glorious the trumpet and alarm ;

Glorious the Almighty's stretched-out arm;

Glorious th' enraptured main.

There was nature at her best, and now for birds at theirs. 
As with landscape, so it is with individual trees, independently of what beauty of shape, colour or ornament they may possess. There was a small juniper in the churchyard where I spent many hours. The church was indifferent, but the churchyard with its noble yews (the pride of so many Hampshire churches), its cedar, cypresses and soft turf had a real character and peace of its own, and it was a pleasant thing to look out from it away to the clear, intense purple of the downs, foreboding storm. In this juniper a pair of linnets had built their nest, and one day I found it quite thronged with the minute, busy, dusky forms of goldcrests, whose fever of restlessness relieved, without marring, the calm of the place. The tree was alive with them, and that common phrase must squeeze all its juice out to express the sudden grace which fulfilled that common tree, as a husbandman fulfills the earth. ${ }^{1}$

Swallows, when they begin to bustle into camp in September for their long journey undergo a physiological change which drags them out of routine. The cries and songs of the little adventurers-palmers for the Holy Land (whither some of them actually go), that have sung their farewells and travelled out their courses so many thousand years before palmers were and so many autumns since their voyagings were donemark the first wrinkles in the year. The young are being fed in the air, and here there is no antagonism between the migratory and the domestic instincts.

One day I witnessed the extraordinary spectacle of a creeper going back for a yard on his tracks! Dean Inge declares, with sublime untruth, that "the normal condition of every species is not progress but stationariness," but I have been an eye-witness of a tree-creeper revolution, as wonderful in its way to all who know their creeper as the resurrections of the human spirit from calamity and disintegration. ${ }^{2}$

1 They pair in January, but remain in flocks for some time. The male displays before the female by running along a branch with drooped wings and fanned tail.

${ }^{2}$ Once I actually saw a creeper go half demented, whirling round and round a tree-bole in an ague of unrest. I should have been hardly more surprised if the tree had taken to its heels. 
Another example. There was only one martin's nest in the village, but so far as I could make out there were three martins to it. One day I found that the sparrows had turned them out and usurped the nest. But lo! two days later the martins were back again at their old nest, all three of them (a female and two males, as I guessed, for one of them remained in the nest making it smooth and shipshape with her chin after the untidy sparrows, and the other two hovered fussily and amicably about her), and held possession without any further interference. There is genuine alchemy in this individual variability and unaccountableness of living creatures.

Once when I was in Porlock, on the Devonshire border, I saw a parent martin, instead of darting about for insects in the wavering, butterfly or rather bat-like flight of this species, fly straight from the nest and perch upon the thatch of a cottage, dipping her snub bill down upon it repeatedly and then fly back to the nest with her booty. This she did again and again, and it was an economical departure from custom. In the evening the sky was occupied in three different layers, screaming swifts in the upper ether, twittering swallows in the middle, and stuttering martins in the lower, no higher than the cottage chimneys, and it was very natural for an individual of the species in the lowest stratum and with the weakest flight to hit upon a new and accessible method of procuring food.

The chiff-chaff is the least beautiful and interesting of his congeners, wood-wren and willow-wren-well called the leaf-warblers-and yet possesses a special quality in which they must yield him precedence. For he is the first of the migrants to arrive, sometimes in blizzards, often at the heels of a withering east wind. Thus he is welcome indeed for his courage and his tidings, as he works at his minute elfin forge of two notes, hammering the new year into its green shape. For little Vulcan is Mercury too, the winged messenger of life, freshness and renewal. His form and song are familiar to all who have ears, and so we regard them not. But violet and chiff-chaff are more important than Bank 
Rates and Stock Exchanges, for these things pass and dissolve in their own transitory ugliness, while bird and flower announce and bring the mighty changes of a planetary system. Like a debutante, he is at his best on his first appearance, and cuckoo, willow-wren, wheatear and blackcap are also near the top of the poll in this respect.

But the cuckoo's analogy is the closest, for he, too, has but two strings to his bow, and as the year matures, so fade the pristine charms of their voices, until a new year restores them. In 1919, I heard the cuckoo's "diminished third" for the first time on April 21st, nine days after the first chiff-chaff, clear, full, pellucid in the bright, cold air. I was lying in a small wood, itself writing the first notes of the old song-" Sumer is icumen in," when the cuckoo chimed in. "The cuckoo is hoarse"-here might be a saying signifying staleness, disillusion, age and decay when a man's life has turned brown. A few days later I was sitting in the evening under an elm when the cuckoo came to perch on it. He hallowed there for a bit, and then set out again languidly ${ }^{1}$ chasing his mate, who dully awaited his attentions on another tree some distance away. You hear but you do not see the cuckoo at his best. A pair of nightjars used to haunt the same ferny pasture towards dusk, crouching lengthwise on a branch, and reeling or flying after one another like giant moths with "silent, searching flight" and low call-cou-ee, cou-ee. Poor cuckoos, poor Thomson to be a contemporary of Collins!

The willow-wren is rarely other than at his best, and if there is anything in transmigration, I shall put in for the willow-wren, so that I may listen to my own strains from morn to eve. A few minutes after the cuckoo, I heard a strain of about a dozen notes in the thick undergrowth of this wood, some fifteen yards away from me. It was the first blackcap of the season (the garden garbler arrives several days later), and a moment afterwards I saw the bird himself, creeping up and down and to and fro among the interlaced twigs

1 Though the cuckoo, whose physiological state is all askewhe suffers from dyspepsia-is the most incontinent of birds. 
of a bramble, and ever and anon his wild and brilliant song came leaping out of his throat. A foot or two away sat a bullfinch, bulky form and sedentary pose of Blackpate No. 2 giving the full romance to Blackpate No. 1. It is nearly always hear rather than see with the blackcap, especially when tree and bush are full-gowned in green, for, with the exception of the grasshopper warbler and hawfinch, no bird known to me is more difficult to watch, partly because of his extreme shyness, partly because he usually sings in the middle of a thick bush, which, rather than the bird, breaks into song, and partly because he becomes silent and slips away when approached. Here, then, in this "rathe" wood were the special conditions I was always seeking and so rarely finding in the shape I expected. The blackcap's song has a brief main figure, a central design, loud, full, ringing, pure, and though delivered with great rapidity and excitement, each note sharply articulated. Some of the notes are very high and clear, like the shape of a jagged mountain on a bright, cold day. But the burden, so to speak, is all decorated and spangled with " a great variety of soft and gentle modulations," as Gilbert White says in his beautiful description, and some of the notes in the "inward melody" have the sweetness and mellowness of a very different poetthe blackbird. There are no trills in the song, and the high-pitched quavering of a robin singing hard by afforded as strong a contrast in sound as did the bullfinch in shape. Now, my blackeap, having but just arrived, left out the inward modulations, to be acquired when he is more at home. Yet it is this image of the blackcap I retain above all others, singing and darting to and fro on a chilly April day in the lap of a bramble, flanked by silent bullfinch and robin with his glittering sprays of sound.

It is an odd thing to record fine things of the spotted fly-catcher, whose disposition is generally assumed to be as drab as his colour-a mediocre, respectable, depressed little bird, sitting hunched on a fence or a gatepost, earning his commonplace living. I have found him otherwise, though a certain grand occasion 
was none of his doing. First of all, he had built a charming nest of lichen and slender grass stems in the rose-bowered trellis of a cottage wall three doors from where I was staying, and had laid therein six eggs, dyed a faint blue-green over a white ground colour, all dusted with rusty brown spots. The parent birds were as bold as brass, for they had found a more subtle way than concealing the nest-advertising it. They remembered that politic saw of Blake's-"Always be ready to speak your mind, and a base man will avoid you." No warbler again is so agile on the wing, and his swift turns and dashes in the air when hawking flies remind me of the swallow. And their coquetries on the wing! They dart simultaneously from opposite perches, meet half-way and flutter breast to breast, and then after some rapid pirouettings and a swift, wheeling love-chase return to their perches.

But I have not yet done with the redemption of the fly-catcher. One day I saw a fly-catcher sitting motionless at the extreme tip of a dead branch at the top of a tall decayed larch, the white breast thrown full out into the beams of the sun. The effect was wonderful beyond any tale of it, for the bird seemed like a globe of dew, suffused with light. Here was an aged and dying tree surrendering its soul to heaven in a ball of liquid light, suspended upon its topmost and deadest twig. Then, moving position, I found that the ashbrown of the back had melted into a fragile, pearly grey, as though it were the palest shadow of the bird's iridescent breast. It was a baptism of light.

It is a fine sight in autumn to watch a flight of mistle-thrushes out of a tall tree, clamorously taking the air with the bold careless sweep so characteristic of the bird's forcible, challenging temper, vehement song and strong markings on the breast. Well is he named storm-cock! I remember finding a mistlethrush's nest in early April in a clump of firs not five yards away from the main road-hogs' highway. As usual, the nest, with its three layers of dry grass, mud, and a surface covering of lichen, moss, and again grass, was very conspicuous, and as I stood looking up a young 
one flew down into the road. I bent down to put it out of harm's way, and its yells at me at once brought its parents to within a couple of yards of my head, tails expanded, feathers ruffled and darting within a foot of my face. The storm-cock rollicks through life like the king-bird of America, singing his "the devil take her." 1

A mile from the village there is a large flag and reed grown pond, with an island in the middle, clustered with many creeping water-plants on the marshy banks, and well guarded not only by an outer fortification of dense trees, but an inner fringe of garlic. The most beautiful lake in the world is but a hole with water in it without its pulse, its local genius and informing spirit-the waterfowl, and I used to spend long periods by this pond watching the teal, mallard, etc., and hearing their greetings, discussions and ejaculations-the crek crek of the waterhen, like the flapping of disturbed water against the reeds, and the peculiar cry of the coot, something between a honk and a cluck, which gives a combination of wildness with peace and serenity to its haunts. The coot is usually called a plain bird, but if the beams of the sun alight on it, the head and neck shine out a glossy blue-black, the white frontal shield gleams in the rays, and the soft slate-grey of the back tempers the whole. But even without the sun's aid, this shield, accentuating the darkness of the bird's plumage, like a flash of lightning in a black sky, has a fine effect. It looks like a fleck of sunlight on the waters, and at the same time protects the bird through its likeness to the dirty white tops of the dead reeds. The likeness is helped by the reflection which gives length. The white webs in the upright tail feathers of the water-hen serve

1 The racket mistle-thrushes make in love-rivalry is far louder than that of castanets at the same distance. I have seen them fighting for love as early as January 5 th, and as soon as two males are locked in combat, off goes the hen, and instantly they leave their broil and take after her, dividing their inexhaustible energies between the love and the war-cry, the chase of passion and fury, the advance of attraction and repulsion, brandishing swords and roses, so to speak, alternatively for hours at a time. 


\section{A VILLAGE IN HAMPSHIRE}

the same purpose. Nature's inspired taste abhors an unbroken surface, a uniformity of colour without relief to give it character and tone. The orange bills of swan and blackbird, the tongue of flame along the crown of the goldcrest, the daw's grey nape, even the narrow white transverse bar across the sparrow's wing, are all artistic devices in the same notation. Nature is sometimes beautiful for beauty's sake alone, but usually wherever you see ornament in her kingdom you will find use, and whenever a thing serves a need, it is yet beautiful in itself.

I had an adventure with one bird which I saw at its best and left at its worst. It was a hawfinch (not uncommon in these parts), and I was responsible for its death in this manner. The people who lived next door to where I was staying kept cage birds in some numbers, and the man in his spare time was a birdcatcher. The pair were pious folks and regular churchgoers, and having paid their respects to the Head Gaoler of the Universe on a Sunday morning, they used to return, and, uplifted with their interview, present their charges with lumps of sugar. Among these feathered convicts-greenfinches, linnets and bullfinches - was a young hawfinch, and the sight of this wildest, shyest and wariest of English birds in confinement made me so uneasy that one late afternoon I bought it and a pair of bullfinches into the bargain, intending to let them out in the woods next morning. I set the bird on my table to get a long and full view of its fine plumage. I judged the bird was in its second year, but it possessed the adult plumage, vinaceous chestnut on breast and belly, mixed with chestnut orange on the head, an ashy nape, brown back, and black on the lower wings and throat. It was a fine specimen, its burly form making the bullfinches look quite delicate in shape, its huge, conical bill protruding from a massive head and a very handsome pelt to match its presence. I was admiring it without compunction when I made the discovery that it was petrified with terror. It stood bolt upright on its perch, rigid and motionless, like an ornament of coloured wood, except for the quick 
rolling and shifting of the eyes. The feathers of the crown were slightly raised as the hair stands upon a dog's rump or a human head for fear of "some fearful fiend." But the eyes were the most eloquent, terrified, but with a certain pride in them. I took the bird out forthwith with the agitated little bullfinches and let them go, and the next day I found the hawfinch lying dead, a few yards from where I had taken it out of the cage. Though not bred in captivity, it was presumably too unused to finding its own food. I do not regret it, for I would rather have killed the bird with my own hands than deciphered that contest of dignity with terror, without restoring it to a liberty at the expense of life. For eyes glazed with death are better than alight with such stress. Many birds, of course, acquiesce in their captivity, but they do so at the loss, if not of the letter of life itself, of that invisible force "whose smile kindles the universe," and theirs is but a death in life.

There are some birds which must invariably be seen at their best, simply because of their rarity. This is not a euphuism; one so sees them, because one sees them in life. My acquaintance with rare birds is not extensive, but I have had my moments. On April 19th a golden oriole (a bird of the thrush tribe as big as the throstle, and, but for the dusky wings, all over a luminous golden-yellow) flashed out of a hedge into the wood a few yards off. I happened to be standing between the hedge and the wood. There is no more to be said. This oriole is a summer visitor, and flies over from foreign parts straight into a glass case. I met him on the way.

The cirl bunting is not so rare and is a resident species. But it is so local in distribution even in Hampshire, its headquarters, that to see it in whatever circumstances is enough. I saw it in good, for it was singing high up in a poplar, fifty yards from my door, its harmonies of olive, chestnut, black and yellow lustrous against the leaves. There has been some controversy about the quality of the song, but, unambitious though it be, it has a character of its 
own. It is in the same notation as the yellow-hammer's, but the quality of the song is superior, for the short notes are louder and livelier, less droning, and each one, though strung on one thread, more roundly enunciated. The resemblance of the song to the lesser whitethroat's has been justly noted.

If the cirl bunting is thinly distributed, it is not at all difficult to watch when found, being a very approachable bird. I have seen him perched on the post of a barbed wire fence a few yards away from the nest with unfledged young in it (as late as the 7th of August). The nests of both the cirl and yellow bunting, with their platform and shallow cup, are neat structures, and very cleverly adjusted to the stems of bracken, bramble, hazel, etc., but both species betray their nests more readily than finches do. The buntings are, in fact, mentally duller (as they are physically more sedentary) than their finch relatives, and their defective intelligence often undoes the work of a far more perfect instinct.

The tawny owl, again, can hardly be called a rarity, except in districts infested by game-keepers, but it is much more rarely seen than heard. I was wandering among the beech hangars on a still, clear morning in early spring, through innumerable smooth columns supporting a delicate filigreed roof, painted in rich purple, grass-green and pale blue, when I came in sight of a large grove of yews, so densely planted that the boughs interlaced overhead and the roots below. They grew at every conceivable angle and bent and knotted shape, clutching at one another in writhing folds and angularities above and below-like a Dürer woodcut. It was an enchanted wood, full of grotesques of a "kindly malice," like the work of a mediæval cathedral craftsman, dramatizing the stone. Through this strange wood there came flying the wood-owl, its ghostly familiar. The picture was phantasmal, a glimpse into some queer world where trees expressed themselves in uncouth gestures and contortions, arguing some mighty debate, not by sound but shape, and the owl by its abnormal sensibility of flight completed 


\section{BIRDS OF THE COUNTRYSIDE}

the illusion. He was twisting with speed and certainty among the boles a foot or two above the floor, more, indeed, like a furtive conspirator than as one at home in his own place. But no conspirator could have crept and curved among those trunks thus noiselessly and with how sure a motion! The wood-owl must, then, possess some wonderfully delicate tactile or sensory apparatus of nerves at the tips of the wings-like the bats-for no bird of day could thus have flown among those close-pent yews with such ease and mastery.

Grey wagtail, stock-dove and sparrow-hawk are none of them common birds in this district, nor, indeed, anywhere in England, except in a few favoured localities, and the pleasure of seeing them is uncommon in proportion. The stock-dove is so much akin in appearance to the wood-pigeon (the ornithological differences themselves are negligible-the rarer dove being a trifle smaller in size, without the white collaret round the neck, and with an infusion of blue run into the grey of the back. The song, too, is a less continuous ripple of sound, the coo-oop being strongly punctuated) that my sensations on the few occasions when I met with it were but the professional ones of adding a new species to my list. On the other hand, I always knew where to find the grey wagtailwhich runs goldfinch and bullfinch very close as our loveliest small bird-for a pair nested in the tangled herbage by the watermill at the head of the pond. The nest is well concealed and made of delicate rootlets, grass and moss, lined with much hair and a few feathers. The eggs (five in number) are greyish-white mottled with brown. I remember one mild April day in particular, when $I$ saw the male in his first nuptial colours, ebony cravat and all, standing on a leafless, sapling ash with sulphur-yellow breast brighter than the sunbeams playing on it. It gave a touch of triumphant and almost fierce beauty to a weather which had at last thrown off its roughness and finally parted from its vagabond winter love.

But an experience I had with a sparrow-hawk was 


\section{A VILLAGE IN HAMPSHIRE}

one rather of philosophy than beauty. This hawk can nearly always be distinguished from the kestrel at a distance, not only because you are much less likely to see it from its greater rarity and its habit of flying closer to the ground, beating the hedgerows and slipping among the shadows of the trees, but from the peculiar and deadly stealth of the flight. One day in early June a sparrow-hawk flew close by me as I was walking in the meadows, between the hangars and the pond, and began prowling about the fringe of trees bordering the water. Suddenly, a pair of willow-wrens sallied out from the rank growth, where they had their domed nest by the water's edge, and attacked her with fury. They swooped fiercely at her, and she avoided them by doubling to and fro. But not for long, for all at once she turned tail and bolted for the wood, pursued for a few yards by the warblers. Many small birds will, of course, attack a hawk en volage, so to speak, and out of business hours, especially swallows, starlings and wagtails. But this was something different. How, then, did these willow-wrens put their special and terrible enemy, against whom they were utterly defenceless, to such ignominious flight? By the exercise of precisely the same moral conviction (apart from imaginative insight and conceptual power) that made Shelley write Prometheus. In the nesting season, birds are literally inspired. They turn over an intoxicating new leaf of life, as the pupa is transformed to the butterfly. Indeed, I greatly doubt whether the sparrow-hawk picks up any nestlings during the breeding season, except when the young have left the nest or the parent birds are absent. Any pair of adult birds, or even single birds at the nest, could rout it, simply because at that time they possess the supreme faculty of devotion and self-forgetfulness it is without. The difference between their inspiration and its routine is enough to turn the tables. Such is the power of a good cause, for later in the year those same birds when they see that same hawk will scream and dive into the bushes with terror. 


\section{BIRDS OF THE COUNTRYSIDE}

But the commoner birds can give us as many precious moments of choiceness and distinction as those less familiar and striking can do, since we have more opportunities of getting them. In a small grove of firs, in that same beech-wood where the tawny owl displayed his parts, I fell in with a party of cole-tits hanging to the terminal twigs of a beech. I looked through the dark sage-green of the firs up at their minute black pates and white cheeks set in the palest apple green, with a thin coating of chequered blue above, and for the moment I wondered whether earth had anything to show more fair. In the wood where I got on terms with the blackeap I once saw half a dozen cole-tits ascending and probing the bark of a birch with the same action as a creeper, except that they used their wings to flutter upwards. These illustrious pioneers were not so beautiful as the beechwood party, but more suggestive, richer in promise, and so quaint, halt, and yet aspiring in their motions, that they reminded me of the cuts in old emblem-books, where the soul wings its way painfully to heaven with a large iron weight attached to its extremities. Yet was this or the other a more revealing thing to see than that far more characteristic one-a procession of tits passing in a hubbub of talk through the leafless trees on a grey winter's day? For birds face their heroic struggle with the elements not by competition but co-operation, standing foursquare to the winds that blow.

\section{II}

The best of throstle and chaffinch is not, I think, in their songs, though at dusk and some distance off the former's sensuous melody is very beautiful. I prefer his soft olive and brown, his attitudes and abrupt, dashing runs on the turf. Above all, the sitting hen-bird's mingling of tenacious, desperate courage in sticking to her nest and appeal from liquid eyes to the intruder have always been more to me than the song, unless I have heard it in more favourable circumstances than usual. Complexity of emotion and 


\section{A VILLAGE IN HAMPSHIRE}

conflict between opposing impulses in birds are always fascinating, and the panting heart of the thrush on her nest telegraphs "fly, fly" to the mind, but the mind at the point of yielding rallies and beats the clamour down, whispering, "stay, stay, and the monster will pass your cottage by, or if he sees you will be charmed from his mischief by the supplication of your eyes." Of course, nor heart nor mind nor eyes make any difference. Who bothers about a thrush's feelings? There was a conspicuous thrush's nest in my blackcap wood where I used to witness this drama whenever I passed through, until there came a day when there was nothing to be seen but a ruin. Sic vos non vobis nidificatis aves! but for any passing hooligan's pleasure in spoliation. I doubt whether one in a hundred first broods of the song-thrush ever get off, for the birds are extraordinarily amateurish in their choice of sites for building, picking out exposed places which compel your attention. Let us hope that Natural Selection is teaching the too eager and amorous thrush love's patience as well as his fire, for, with so clever a predatory animal as man to cope with, it behoves it to wait until its homes are well screened from prying eyes. Of course, late broods do make up some leeway, or the race would be extinct, and it is probable that the nesting season is already less premature. It is that or greater prolificacy, and I have myself seen young thrushes as late as early October.

The chaffinch's song, again, pleases me as a jovial, natural sound, and a bold, and for little else. It enlivens the heart more for its association than its intrinsic sake, and is coarse, flat, and metallic in musical quality. The melodies of yellow-hammer and wren are also set phrases, but they never fail to give delight. The interest of the chaffinch's song is one of character and manner, not sound; it is a defiance, a king-of-the-castle challenge, and it shouts " $\mathrm{Ha}$, ha!" as it smells the battle afar off, the thunder of the captains and the shouting. The chaffinch is finest in his spring coat of many colours, black, grey-blue, green, chestnut, yellow and white, as he puffs out his chest on a twig and dares his fellows 


\section{BIRDS OF THE COUNTRYSIDE}

to dispute his fair, or chases her in wild circles and headlong dives through the air.

But these standards read rather more absolutely than I intend them. The human mood and attitude so constantly alter values that the significance of a bird's action shifts in proportion, and precisely the same spectacle appeals to the mind one day and the eye alone on another. One warm day in late April I was lying upon a hillside overlooking a bountiful stretch of woodland and pasture with the rounded curves of the Sussex Downs rising beyond it. Here one could have lain thoughtless, silent and absorbed for hours, in a serenity gradually enfolding one as the sea covers a rock. One begins to find out what it feels like to be a tree. Then suddenly a yaffle flew up right from the valley, passed over my head and alighted on a tree fifty yards away. The open view I had of the bird, the transition from repose and immobility to the most rhythmic of all movements-flight-gave me the sensation of rushing through the air more than I have ever felt it before, while the nature of the yaffle's flight, its curving, sweeping lines, the pauses in the wing-beats, the drop and recovery all contributed to snatching me from the ground. Had it been a wood-pigeon, and had I seen this flight in any other confluence of conditions, I should have stayed where I was. Yet a yaffle on any other day would fly as fast.

There is one bird whose best is distinctly his worst in all circumstances, and that is the corn-bunting, largest of his family, and commoner in the valleys than the yellow-bunting, while on the uplands the positions were reversed. The song has been compared with breaking glass, a rattling chain, the alarm-notes of the skylark, the wheezing in the pipes of an aged rustic, and the squeezing of pebbles together. I defer to these just and inventive similes, and have only to add that, unlike the yellow-bunting, who demands both bread and cheese, unlike the cirl, who leaves out the cheese, the corn leaves out the bread. "Quick, quick; cheese!" he says, and the style, semi-articulate, slurred, thickened 
and in the rough, is exactly the bird. One morning I watched a corn-bunting having a mud bath in the road, fifteen paces from where I stood, plainly visible to him. There he was in his chequered and untidy plumage of various shades of brown, gravely standing on his chest, with his beak planted in the water like a walking-stick. He then solemnly elevated his tail, proceeded to some perfunctory flutterings of the wings, stopped and had a look round, and went on with his ablutions again. At the end of this ceremonious rite, this consequential purification, only his breast was wet, and he looked just as slatternly and dishevelled as he did at the beginning. Thus he goes muddling dowdily through life, wearing it like an ill-fitting coat, and always indolent. I love him for it, and how could Mr. Hudson have the heartlessness to write an apology for this best of all companions on a grey day?

I have nothing to say of the nightingale in this district, for all I heard of his performances that year was a croak, and that was over the Surrey border. The bird was certainly rare in all the Southern Counties in 1919, and the blizzard in early April must have caused a heavy mortality among them.

I must, however, relate my experience with nightingales the following year, and not in Hampshire, but at Boar's Hill near Oxford, because the nightingale is extremely capricious in the opportunities he gives you for seeing or hearing him at his best, and I know no other native singer, with the possible exception of the blackbird, who is so variable in the quality of his song. I feel diffident of disagreeing with Mr. Hudson, with his divine intuition into the life of the bird and his wonderful ear for bird music, but all the same I cannot see eye to eye with him or listen ear to ear, when he says that the nightingale of the poets is a very different thing from the nightingale of reality. I have no doubt that he is by far the finest warbler we possess, perhaps, with the exception of the white-banded and other less superb species of mocking-bird, the finest warbler in the world.

The song lacks tenderness-parts of it are a pelting 
rain of hard jewels-but it has three characteristics which crown it. First, there is the perfect phrasing, the mastery of workmanship, the sheer lyrical power; secondly, there is the marvellous variety of pitch and tone, and, thirdly, the passion of the music, its fieriness and plangent strength. The daringly high prelude-wher, wherw, wherw-repeated sometimes a dozen times, peals out, and there is silence; then a wire twanged, as though an invisible hand, delicate as Oberon's, struck his stringed instrument with tremendous force, until the leaves of the tree seem to vibrate with the sound, and silence again; a rich, mellow, rapid warble, and again silence; a liquid, bubbling note followed by a clear, bright whistle, wind and stringed instruments snatched up in turn.

The first nightingale I heard at Boar's Hill was in full view on the low branch of an elm in a thick copse bordered by water-meadows, nor did my rude presence so close to him at all disturb him. But I had heard better singers, and as evening drew on, and the sun put its head through its golden garland of elm-leaves, the bird fell silent and sought his invisible mate, who all along had answered his fierce wooing with little stray exclamations. She fled his burning love, and among the fluttered leaves of the elm, before the chorus of the song, and now the bower for his winged dance, he played out his throbbing notes in action, in a chase of wild dives, circles and dashes, a full, tawny and silverwhite in the level rays of the sun. Then the moon usurped the sky, a more spiritual sun, and two other nightingales struck into music, a more spiritual music, which continued until past midnight. One of these songs, apart from all the magic of association, was of a beauty and purity excelling those of any nightingale I remember to have heard. His melody was not sung for me, nor even for his listening mate, lulled upon her eggs in her oak-leaf cottage, for it seemed the enraptured voice of all nature, her "alleluia sweet and clear" to the Author of her being.

But we are in Hampshire, not Oxfordshire.

Memory tells me that magpies and jays filled my 
mind with colour more than any other bird I studied in the neighbourhood of this Hampshire village, especially the magpie. Both of these splendid and gifted species were surprisingly common in the district, and one day in early September I recorded the fact that I had seen no fewer than forty-one magpies (mostly at the foot of the hangars) with as much self-importance as though I had been decorated with forty-one medals. No doubt I saw the same bird more than once, but at any rate there they were in the abundance they used to be and ought to be. It reminded me of the days when they used to congregate in assemblies, like lyre-birds, birds of paradise, ruffs and reeves, blackcock, etc., many of whose spring rites are being broken for ever. I used to watch these pies, too, in all conditions-feeding on the meadows (sometimes in the same field with hens and young chickens); flying along close to the ground and making that half-turn before alighting which displays the iridescent plumage full face, so to speak; making for the thin sky with long rudder-like tails behind and short, rounded wings beating like a screw, frothing the pied plumage into a soft, misty grey, and sounding their rattles among the trees. Like the wagtails, magpies are always in several minds; feeding is the most frolicsome thing in the world, and delightful and abrupt sensations dash in upon them one after another, possessing them and finding expression in singular and as it were parti-coloured action. Not that he is incapable of the pontifical manner. $\mathrm{He}$ will stroll comfortably across the field or doze in the sunlight, until suddenly the Castle of Indolence is razed to the ground, the tail rears itself up at right angles to the body, and the body is slewed wildly round. Or he seems to stand on his bill with wings fluttering like pennons in a gale; or he takes a three-step sideways hop, as though to confound all continuity. Indeed, you never know where to have your bird. He is not even a pie, strictly speaking, for his bold, contrasted plumage is glossed, shaded and graduated by gleaming tints of green, violet, grey and metallic bronze. His note is described as a chattering or bleating, but he possesses 
a quiver-full of different sounds, and the chatter itself expresses a varied repertory of emotion. In the wood where I had heard the blackcap I once frightened off a wood-pigeon and a magpie from their nests on the top of a maple and a lofty Scots pine. The pigeon went right away with a clatter of wings, but the pie only flew to a tree a little distance away and uttered the usual rattle, but in it the tautology of anxiety.

Surely there must be a few landowners who have opened their eyes and minds to the decorative effect of a pied troupe of from a dozen to a score magpies upon their land. They light the English landscape up and make it so strong and savorous that one would have thought an owner who held his land in trust rather than for exploitation would preserve magpies as jealously as vicars do the ancient yews in their churchyards. Magpies are to English woodland and pastures what the place and other names are to "Paradise Lost."

Many an avowed protector of birds is as bad as any oaf with a gun. One of them told me that he shot jays and magpies to give other birds a chance. What sort of amphibians, then, I asked him, do you call jays and magpies? It is this kind of thing that opens the cause of protection of the just charge of sentimentalism. These are the soft, cruel hearts of which Bernard Shaw speaks, for where could you find a better example of meddling sentimentalism than to coddle some species at the expense of others? Let the small birds take their chance, as nature meant them and brightened their faculties to meet it, and if the magpie does sample an egg now and again, then let him!' It is not so much the big landowners who are responsible to-day as the profiteers who have bought up land. The worst of "vermin"-killers and pheasant-preservers is your city man who has made his pile in all lawful dishonesty. Soon, too, when the supply of foreign birds runs short, the women will be after their plumage.

In the beginning of June I set out to explore the banks of the little river Rother, which joins the Arun near Petworth in Sussex, but is seldom more than thirty paces wide in this part of Hampshire. 
To walk beside an English stream being one of the choicest, is naturally one of the rarest of pleasures, and no sooner was I strolling under the willows than an angry game-keeper bore down on me. He drove on like a sedge-warbler, though in a less agreeable voice, but it was really the so much A B C of his profession, for he soon came to see that I was a harmless dolt, and promptly took me off to see a snipe's and a kingfisher's nest-a conduct which confounded me much more than his railings. The former was a jerry-built affair of grass-stems in a thick tussock of a rough field, and the latter was an enormous hole in the roots of a fallen beech projecting over the edge of the streambank, and more appropriate to an otter than the winged star with orange, azure and emerald lights, who shoots rarely now along our English waters. The kingfishers' burrows I have seen have been no larger than a sand-martin's, and it is probable that the kingfisher occasionally uses the discarded ones of this martin. I watched for some time, but seeing nothing but dragon-flies (Calopteryx virgo?) winged pure turquoise, moved on upstream, and a luxuriously tangled Bower of Acrisia I found this river-valley-deep wood on one side, lushy meadows, osiers, alders and rushes on the other; water voles in the bank, water-hens on the stream and silvery fish beneath it. I found no reed-buntings, but in a tall reed-bed (a foreign importation, rather like a thin bamboo with the stalks banded green and brown at regular intervals) I found a reed-warbler's nest with five young, warm, pulsating, downy balls of life, the mandibles opening to the touch of my finger by reflex action. ${ }^{1}$ The nest was a notable piece of architecture, deep, cup-shaped, neatly slung seven feet from the ground, and woven round the stalks with dry bents, moss and flowering grasses, with a lining of horsehair and feathers. While

1 This is one of the few obligatory movements of young birds. Birds, being big-brained and educable, are not endowed at birth with a heavy battery of reflexes and tropisms. They are readymade only in structure, and time bites upon them from the egg. For the way chicks profit by experience, see Lloyd Morgan. 
I was inspecting it the parent bird (the female had flown right away on my approach) was swinging his restless, shadowy form (it is quite easy to distinguish from the sedge-warbler, whose back is fretted, the reed's being uniform) among the columns of the reeds, singing and scolding with all his might. The bird was never more than two or three yards away from me, and I caught the girding notes in the song full. But it struck me as very beautiful, copious, refined, sparkling with high-lights of lucid and penetrating notes, a breeze among harebells, sometimes soft as the golden-tinted down shed by the sun upon the evening sky. In the same clump, some five feet from the ground, I was surprised to find a blackbird's nest with eggs (a second brood, no doubt), suspended and woven among the stalks (though with less art) in the same way as the reed-warbler's-a unique discovery in its way.

I then walked on for another mile, until I emerged from the banks of the river before a house with usedup, dusty, short grass in front of it. Between the bank and the house was a small sand-bank with a few holes in it, ex-residences of the sand-martin, who, like his congeners, becomes rarer every year. I stood idly looking at it, when into one of the holes plunged a kingfisher, and I got within a dozen feet of the frontdoor before out he came like the sun from a cloud, flame out of coal, an inspiration from the mind, out from the tawny sand, a Psyche of iridescent coloured lights! Things were bound to fall a bit flat after this, but returning homewards, I was pleased to find a nuthatch's nest half-way up the trunk of a birch, a neat hole, carefully plastered with clay to prevent the incursion of any house-breaking starlings. Woodpeckers are not such a match for the starling as the nuthatch. ${ }^{1}$ The dragon-flies, vibrating their translucent wings in a jewelled mist above the guelder-roses near

1 It is just possible that sparrows and starlings (related to the parasitic cow-birds of the Argentine) are beginning to take the wrong turning in life. In bygone ages the cuckoo probably began sowing her wild oats by stealing nests. 
the keeper's cottage, were a glorious thing to see, and I noticed three more species, one dark bottle-green (wings and all), another with orange-brown wings and pale green body, and a third purplish-black with coruscating green wings, like the pirates in a pantomine.

I went with the keeper to see his kingfishers (breathing no word of my own), but we only saw them meet for one to relieve the other and exchange a tender greeting at the nesting hole. It struck me that these kingfishers were breeding very late, and the ones higher up the stream, no doubt, had nearly fledged their young. 1

My trespassee was a queer one. He told me he had always refused the bribes of bird-stuffers and collectors to kill the woodpeckers, kingfishers and other rare birds on the estate, and took pride in calling himself most exceptional in this respect. For my part I told him candidly what I thought of the ignoble business of pheasant-rearing. So far from resenting what I said, he seemed to comprehend my point of view, and I could see that he shot his "vermin" (he killed a hobby once) with reluctance, while owls he had the surprising good sense to spare. Indeed, he had a genuine liking for birds; my sort was a secret vice to him, and listening to me and half agreeing a kind of delightful drug. Neither did he indulge in any of the usual sentimental moral cant about "good birds"

1 Courthope, by the way, mentions the Rother and its kingfishers in The Paradise of Birds.

Oh blissful hour

When Blanche and Flavia joined with me,

Tri-feminine Directory,

Dispensed in latitudes below.

The laws of flounce and furbelow.

And held on bird and beast debate,

What lives should die to serve our state !

At morn we sent the mandate forth;

Then rose the hunter of the North,

And all the trappers of the West

Bowed at our feminine behest.

Died every seal that dared to rise

To his round air-hole in the ice ;

And by green Rother's reedy side

The blue kingfisher flashed and died. 
and "bad birds," understanding very well that moral distinctions between the man who coveted a monopoly in killing for self-indulgence and the bird killed by man because it obeyed the law of its nature in killing the same prey for food had better be left alone.

All around us were the pampered pheasant chicks, in special coops, in a special field, fed on special grain food, with special hens to brood them and special men to guard them day and night-here was the whole expensive paraphernalia of elaborate waste to gratify an atavistic pleasure. Simply in order to enable a few rich men, "butchers by battue," to plume themselves in killing off so many tame birds in so many hours, the whole wise balance of nature has been tipped to the beam. I asked him whether he agreed that the persecution of their natural enemies had been responsible for the increase of the wood-pigeons and sparrows there has been such an ado to keep down of late years.

"Yes," quotha, "but__"

"Spare me that," said I; " or do you really believe that game-preservers (what a queer way we have of preserving in order to kill and killing in order to preserve!) kill off the crows and hawks and owls for love of warblers and finches?" 1

But we parted on the best of terms, and as a mark of his esteem I was presented with a tract, which I received with as much blushing gratitude as though I had been handed a silver cup at a ceremonial dinner. So I packed off into the dusk, thinking of what I had seen and of our warfare on birds for economic reasons, on those very birds our magnanimous gamepreserving system protects from the cruel hawks, thinking, too, of nature's own kind wisdom, who loves all her creatures impartially, who desires all of them to live in the sweet sunlight to their fullest intensity, but will not sentimentally pamper one to the exclusion of another. But on one side of me the hedge was starred with white campion, on the other the field

1 I recognize, of course, that the preservation of rare, small and delicate birds owes a great deal to enclosed estates. 
was a mass of crimson trefoil, tipped with delicate pink. How can we be mad in such a world as this, I thought. Beauty we fear and slay, because it lurks somewhere within us all like a snake in the grass.

A second day was a golden calm one in September when the mid-summer trance was over and the sleeping princess was once more bustling about her green manor. Cole-tits were busy in the oak-copses as I passed by them on the way to the station, but the oxeyes seem to prefer strutting along the top of the wayside hedges in their new yellow waistcoats. I felt my moult was safely through, and, carried in the train, that I was migrating of my own volition. So I arrived at Midhurst Common (which is just over the Sussex border), and found myself in a trice staring at a small pond on the south side of the railway (which cuts this fine common in half). Upon it there was a pair of coot, of water-hen, and of dabchicks, with a mute swan accompanied by a single, well-grown and handsome cygnet, thrown in. I say thrown in because a swan on a small pond looks like a duck in a puddle or John Bull on his island in a cartoon, ridiculously disproportioned to his background, and so ugly for all its whiteness. The cygnet was the only young bird, and the bodyguard of reeds and reed-mace with their swords and clubs had been unable to save the eggs of the wild birds from piracy.

The pair of dabchicks took no direct notice of one another, but from time to time sent joyous and affectionate calls tripping over the water. Mr. Edmund Selous describes the liquid, inflected call of the dabchick as a "hinny," and that's good, but too harsh. My own version is a kind of silvery yodle, wild and of the water, watery. It is like a single long spider's thread hung with raindrops, each one pure and bright, and is to the pond and river what the windy tremolo of the wood-wren is to the beech-grove. In actual sound, however, it comes nearest to the blue-tit's spring song. In spite of this, I find it difficult to account for the singular charm these shy little grebes had for me. The coots with their shining white shields and 


\section{BIRDS OF THE COUNTRYSIDE}

black necks, the water-hens with their red lamps and flicking striped tails were doing all manner of interesting things. Yet these birds, performing their monotonous routine, seemed to make the others commonplace. The distinction may partly be due to the affectionate contact they kept with one another, partly to the effortless precision of their movements, and partly to their perfect adaptation to their home, since the greater the absorption of an object into its natural environment, the truer and stronger the impression upon its observer. Grebes, little and great, are far more aquatic than amphibious mallard and water-hen (who feed in troops on the meadows like hens) or ponderous coot.

Over the whole common I found but three linnet sprites, launched like shots from a fairy gun through the air and in full melody. It is easy to tell linnets in flight, even when silent, so high and with such velocity and buoyancy do they career along. Then, in a breath, down they come sheer, as though the wind of inspiration had blown itself suddenly out, or round they steer in another direction, as it catches them in flank. This fine common should swarm with them, but that blight, that ferret, the bird-catcher, has doubtless done his work here as elsewhere, though linnets, like goldfinches, are such air-trotters that one grasps the benefit of the doubt, whether fallacious or no.

An odd experience $I$ had in this part of the common was the sight of a wren on the branch of a stunted willow within two feet of the ground scolding a large adder. The snake's head was raised and swaying, and it regarded the wren, so vehemently denouncing it, with an imperturbable cold stare like the stare of Ozymandias's "shattered visage" over the desert. I have no doubt that the wren would soon have fallen into the adder's jaws, and though theoretically I do not believe in sentimental meddling with the interrelations of wild animals, yet I stamped and saved the wren who promptly transferred his abuse to me. Yet we hesitate to allow human characteristics to birds ! 
By far the commonest birds on the common were cole-tits, which I met everywhere. They are quite fearless of man, and in a little pine-grove where I sat down they spun round the twigs and gambolled and bustled and chattered and postured and stood on their heads about me, like as if I were no more than a giant fallen cone. I prefer their shriller, crisper, more vibrating notes to those of all the tits, with the exception of tomtit's spring bell. But I had a rarer experience than this, for a pair of jays (without young, like the water-birds) dropped in on the pines. There it all was in the flesh, as Hudson describes in Birds in a Village, crest raised and depressed, bright eyes narrowly regarding me, head bobbed, wings outflung, feet perching now on one branch now on another, and cinnamon body, embroidered with black, white and blue, radiant against the dark trees. Never before had I seen jays so tame and so at my ease, and this pair, at any rate, cannot have known persecution.

How readily the quick-minded bird sloughs a habit! My old friend Squire's vivid picture of its unchangeableness in his poem, "The Birds," is a bookish one. We do not ask our poets to be expert ornithologists, but if their poetry will not square with the truth of the universe, whether as observed or divined, it is no more than picturesque. For if birds were the fixed quantity ("They are unchanging: man must still explore ") he represents them, they would, of course, have been extinct centuries ago. The truth is that the entire conglomerate of organic-yes, and inorganic life-is on an exploring expedition, prospecting for God, crystals no less than man, and immobility (as Blake knew very well) is the sin against nature, if it be not another name for hell itself.

It was a melancholy business on the north side of the railway, once pine-wood and heath merging into a large, wooded, private estate. The utilitarian hackers and hewers (a utilitarian is a creature who destroys beautiful and useful things for ugly and frivolous purposes) had been there, and the ground was like a battlefield strewn thick with the bodies of pine, fir and other 


\section{BIRDS OF THE COUNTRYSIDE}

trees, with heads and limbs sliced off and numbers rotting into pulp where they lay:-

Sure thou didst flourish once! and many springs, Many bright mornings, much dew and many showers, Passed o'er thy head; many light hearts and wings, Which now are dead, lodged in thy living bowers. But thou beneath the sad and heavy line Of death, dost waste, all senseless, cold and dark ; Where not so much as dreams of light may shine, Nor any thought of greenness, leaf or bark.

Nothing grew on the ground, nothing moved except the surfeited boring beetles, and I made haste to escape and trespass into the estate, where it was almost as bad, for I found no life in it, except one squirrel and four cole-tits. Woods nowadays are haunted not by ghosts, but silence, vacancy, desolation, which might well take terrifying material forms. They are what the whole country will be like one day, unless something drastic happens to men's minds. It was good, then, to hear a murmur from a willow-wren by the station, tenuous, fragmentary, scarce audible, but still warm with old joys and exorcizing the evil spell. 


\section{CHAPTER VIII}

\section{GHARLES WATERTON}

TN these days, when the rich diversity of human 1 kind is the unpardonable sin against the Holy State and the drains of thought are always in order, I turn to one of our old naturalists with a pleasing sense of profanity.

"If you dissect a vulture that has just been feeding on carrion, you must expect that your olfactory nerves will be somewhat offended with the rank effluvia from his craw, just as you would be were you to dissect a citizen after the Lord Mayor's dinner." Yet the man who could give so imaginative a twist to the study of Natural History is neglected! Charles Waterton was a Yorkshire squire, the owner of a large estate (Walton Hall) near Wakefield, where he had a bird-sanctuary, stocked with many an ornithological rarity. Just after I had been reading Waterton I happened to take up Wallace's account of a voyage up the Rio Negro, a tributary of the Amazons. In one portion he describes how he organized an entire village to slay the orange " cock of the rock" for a fortnight. The Amazon forests, says Wallace, are more silent and empty of life than the Sahara. One sometimes wonders, as one gazes in rapture upon the triumphs of scientific destruction, whether in some magnificent future age it will not (as it approaches the sources of energy) discard machinery altogether and invent a race of men who, by the simple process of a pestilential vapour from their mouths, will be enabled to wither and destroy every living thing within a radius of a dozen leagues. Unconquerable race, I prophesy thee in a transport of Utopian zeal! So that the verdict of the museum as to old Waterton's eccentricity (partly no doubt because he would not have 


\section{BIRDS OF THE COUNTRYSIDE}

his feathered friends exterminated for the cabinet and glass-case) need not prejudice the lay mind. The more gently disposed will seek the explanation of a certain quaintness in the squire's personality upon rather different grounds, " quando," as his pious biographer Dr. Hobson remarks, "ullum inveniemus parem?"

Except the Wanderings in South America delightfully reviewed by Sydney Smith, a ravishing account of adventures with caymans and boa constrictors in the Guiana wilds, Waterton's works have been seldom reprinted. They consist of three volumes (1838, 1844. and 1857) of Essays on Natural History (chiefly about the habits of birds, the National Debt, dressed and served up $a$ la Cobbett, spiced with tart references to the wearing of cravats, and the amours of rattlesnakes). To each of these volumes is prefixed an autobiography, and-as a grand orchestral finale-there is a biography by Dr. Hobson, of Leeds, Boswell, physician and friend. The biography is one of those books which are so bad that, like high game, they become as palatable to the literary digestion as the freshest art. There are positively no infinitives in it that are not split. The finny squadrons, the feathered tribes, the vulpine race natate, volitate and perambulate throughout the book, and to read the biographer describing the drolleries of the squire shinning up trees, "whirling himself entirely round in the air," "dropping on one foot" and returning " by hopping back on the contrary foot," declaiming, "Non de ponte cadit qui cum sapientia vadit," is almost as good as seeing a hoopoe.

The greater part is taken up with a survey of Walton Hall, and oh! in a manner compared to which the magisterial Baedeker is pyjama literature. "My thoughts ... in an occasional leisure hour... on paper." No, no, Dr. Hobson! But we must permit him, without interference, to conduct us round the extensive circumference of a domain so well garnished and populated by an unparalleled assemblage of the feathered tribes. The estate was of an "amphitheatrical configuration," embellished by a lake, whose "finny contents" therein disported themselves. There, "in 
his genial element every inch of him," Waterton in a battered top-hat (like Dr. Hobson's style) would stroll with him (absque sudore frontis-" without perspiration on the forehead"-for, unlike the squire's, all Dr. Hobson's Latin quotations are carefully translated, and we are never in doubt as to what " $T u$ mihi magnus Apollo" means) and study the ways of his orchestral guests.

So well were the birds acquainted with their protector that there, at the "apicial extremity" of a bough, is one "constructing a fabrication" (as it were in a verdant House of Commons) of moss and straw before the very eyes of the onlookers. Within the house was a large telescope, from which could be seen, for instance, the "uncertain tenure of equilibrium" of the coot on her nest. The squire himself is not unworthy of study. There was nothing he could think or do but in his own original way, for he was a staunch Roman Catholic (that religion which worships a God who cares nothing for His birds and beasts), and always attributed his great bodily strength to the Jesuit Fathers at Stonyhurst College, where he was educated to abstain from all spirituous liquors. He made up for this abstention by spiritual draughts of unusual potency, for he relates with the most solemn testimony that when he was at Naples he witnessed the miracle of the liquefaction of St. Januarius's solid blood, repeated on January 1st of every year since the lamentable death of that martyr. But I doubt whether temperance had much to do with his massive frame, for the grave Hobson remarks that, while he took no drink, "he was incautious and by no means even ordinarily discreet in the consumption of solids."

Inside his house, he had playfully fashioned a number of figures in taxidermy representing prominent personages of the Reformation. "He also associated with our most distinguished characters of Church Reformation a sprinkling of his fancifully suggested or supposed inhabitants of the infernal regions, not, of course, forgetting to introduce, in a moment of vanity, the 'Old Gentleman' under the cognomen of 'Old Nick'." 


\section{BIRDS OF THE COUNTRYSIDE}

But, in spite of a somewhat vigorous confidence in the faith, there was nothing actually stiff about our naturalist either in mind or muscle. At a ripe age he met his old friend, Captain Jones, in Rome, "when we visited the castle of St. Angelo and contrived to get on to the head of the guardian angel, where we stood on one leg." When he was seventy-seven, "I (Hobson) was witness to his scratching the back part of his head with the big toe of his right foot." ("If they should see their bishop stand, His foot supported in his hand.") Indeed, the Home, Habits and Handizork (1866) of Hobson's is very happily stored with records of the squire's "callisthenic feats." In his eightieth year he would show his pleasure "in receiving me by actually dancing down the whole length of the broad walk, occasionally throwing one of his loose slippers from his foot high up in the air above his head and expertly catching it in his hand in its descent."

At an advanced age he made himself a pair of wings, and would have sallied off the roof of his stables had not his Boswell arrived in the nick of time to remind him of the fate of Icarus. Being so excellent a Latin scholar he desisted. In 1850, he was up in one of his trees. "Suddenly the ladder swerved in a lateral direction-I adhered to it manfully; myself and the ladder coming simultaneously to the ground with astounding velocity." Partial concussion of the brain was the result, somewhat aggravated the same day by his servant withdrawing the chair he was about to sit down upon. Never did virility of body and character emerge so triumphantly from a sufficiently searching test, for the one survived the ministration of the local bonesetter and his own blood-letting and aperients, the other resolved in the future "to mount into trees without the aid of ladders." "And here I am just now, sound as an acorn," having arisen from "my expected ruins." At any rate, from strangling boa constrictors in the Guiana wilds (first thrusting his hat down their throats) to his arboreal exercises, he certainly did throughout his long life display no less robustness of body than of faith, no less agility of muscle than of mind. 
He would have nothing to do with banks, keeping his "solid tin" (the squire's colloquialisms are the light to the doctor's umbrageousness) in a deal box. Politics-

"If driven to extremities, I had rather be slain by the sword of a Tory at noonday than be stabbed at midnight by the muck-fork of a sinuous, tortuous, treacherous Whig.... Poor Britain ! I pity thee from my heart. What with Jew and what with Gentile, thy Parliament House will soon want a Lord Protector with his whitening brush. 'Sir Harry Vane.' The Lord deliver me from Sir Harry Vane."

Our "Spes Danaum" naturally refused to take Sir Robert Peel's Oath-though, as he justly says : "I don't believe that Sir Robert cared one fig's end whether the soul of a Catholic went up after death to the King of Brightness or descended to the king of brimstone," his only aim being to secure "full possession of the loaves and fishes." Still, he cannot help casting a compassionate eye upon poor Britannia with her mortgaged shield, spear and helmet, and Cobbett advancing upon her armed with the keen and gleaming weapons of his prose :-

"A debt of $\$ 800,000,000$ sterling (commenced by Dutch William of glorious memory) is evidently the real cause of her distressing malady. It is a cancer so virulent, so fetid, so deeply rooted withal, that neither Dr. Whig nor Dr. Tory, nor even the scientific hand of Mr. Surgeon Radical, can give any permanent relief to the suffering patient. So fine a personage reduced to such a state! Thank heavens, we Catholics have had no hand in thy misfortunes !"

Against all the "mean-spirited and mercenary recreants" who ill-treated animals he directed blows of eloquence no less vehement than those of his physical agility. Indeed, his darling sin of quotation was apt to play more than usual havoc with proportion when sacra indignatio was the stimulant. When he heard of some linnets being blinded to make them sing the sweeter he burst out in a fury : "Monstrum horrendum, ingens, cui lumen ademptum!" But from the "initiative inchoation" of Waterton's 
Rumtifooian character, as delineated by the brisk and pithy Hobson, let us turn to the autobiography. Being tanned and furrowed by wandering barefoot in the tropics, this muscular and supple epigrammatist was in personal appearance "half Rosinante, half Bucephalus," and "on taking a view of me from top to toe you would say that the after part of Tithonus had been glazed upon the lower part of Ajax." He was, he says, descended from Sir Thomas More, and the Catholic Watertons were, of course, eclipsed since the sway of "that ferocious brute, Henry VIII," that "adulterous king with his cormorant court," a very proper father to the "old virgin queen" who resides not among "those happy souls who dwell in yellow meads of asphodel," but "in the sulphurous walks beyond the river Styx." I would, he says, "rather run the risk of going to hell with the Venerable Bede than make a dash at heaven in company with Dutch William."

At school he was a nailer for finding birds' nests, and the birch merely inflamed "my ruling passion." "Thus are bright colours in crockery-ware made permanent by the action of fire; thus is dough turned into crust by submitting it to the oven's heat," is our hero's Euphuistic comment upon the efficacy of reformative punishment. After leaving the Jesuits' college at Stonyhurst, and enjoying a run of fevers and earthquakes in Lisbon, he went to Demerara, and had some desultory fighting with the Spaniards up the Orinoco. The corpulent Governor of Angustura affords him an opportunity for one of those racy Panzaisms with which his works are pitted: "He (the Governor) had not got half-way through his soup before he began visibly to liquefy. I looked at him and bethought me of the old saying, 'How I sweat!' said the mutton-chop to the gridiron." Then follows a maze of adventures and long wanderings between 1804 and 1825, told with such candour, not to say ingenuousness, that I can only exclaim with him against the scurrilous Swainson, the naturalist and green-eyed monster who threw a shameful doubt on them. 
The Government would have nothing to say to this " most intrepid" explorer, but he did at last get a. commission through a friend to penetrate Madagascar. His star beckoned him :-

"Come and show to the world that conscience and not crime has hitherto been the cause of your being kept in the background;: come into the national dockyard and refit your shattered bark. which has been cast on a lee-shore, where merciless wreck-seekers. have plundered its stores."

A tertian ague loomed up like a black cloud, and "the star went down below the horizon, to appear no more."

Expeditions to Guiana to procure the Wourali poison, visits to Germany, Italy and Belgium followed. In 1825 he was in Bruges, when the Belgians were revolting: for religious liberty. As the balls whistled round, he sought shelter at a half-open door. "Just as I arrived at the threshold a fat old dame shut the door full in my face. 'Thank you, old lady,' said I, Felix quam. faciunt aliena pericula cautam." The first part of the memoir concludes with a discourse on death and his own hairbreadth escapes in the jungle, alarming to. readers, but not to him, well fitted for them ("Would a 'pampered menial' storm the deadly breach? Would a gouty alderman descend the Rock of Ailsa, based by the roaring ocean, in quest of sea-fowls" eggs?"), remarks on religious toleration ("I think I may venture to assure their reverences that $I$, for one, will never use gunpowder in an unlawful way"), and a dirge on the National Debt.

Part II opens with an account of how he rid his: estate of the "Hanoverian rat," whose depredations. " exceeded those of Cacus." "In the year of grace, 1839, the premises were cleared." After a learned discourse on the Wourali poison, he now travels, with a protest against the "unbecoming sneers" against the Catholic religion conspicuous in nearly all books of travel. $\mathrm{He}$ is a long while appreciating the storks in Holland, until he breaks off in the middle of a sentencewith the remark that his intention was to present the 


\section{BIRDS OF THE COUNTRYSIDE}

reader with only one small volume, "like the song of the stormcock in the month of December." In Italy, " represented so voluminously by different and indifferent English travellers,"

"the traveller cannot walk the streets in comfort, unless he has his lavender-water with him," and "the Italians would confer a vast benefit on society if they would deposit more fertilizing matter in their fields and less in their streets ; or, in case the first is not considered necessary, they might imitate the excellent example of the good people of Edinburgh in the olden time, when they had a man clothed in an ample surtout, crying up and down the streets at night: "Wha wants me ?'"

What struck him particularly there was the dearth of combs. They must have been scarce in the time of Horace, "for he remarks of Canidia, "crines et incomptum caput',"

The Italian countryside he found as empty of birdlife (he compared it with "Ovid's memorable description of Famine") as it is to-day, thanks to the honourable tradition and habit in that refined people of dining off warblers. But the material for the entomologist, if not the ornithologist, was to be found in the towns :-

"At the town of Monsilice there was nothing in the way of Natural History, saving, that in passing along the street, there was a goodly matron sitting on a stool, and with her thumb nails impaling poachers in the head of a fine young woman, probably her own daughter."

In the streets of Rome, recollecting a happy old custom, he would stop the beasts of burden and cry out upon them: "Benedicite, omnes bestice et pecora, Domino!" At another time, being warned of the dangerous buffaloes on the road to Naples, he spied a herd, advanced upon them, "and immediately threw my body, arms and legs into all kinds of antic movements, grumbling loudly at the same time." They "took off, as fast as they could pelt." At "otiosa Neapolis" the miracle of St. Januarius receives a round dozen of pages. Sir William Hamilton, our former Ambassador, wrote to the Royal Society, he affirms, in 1767, in the following words : "It is well attested that the eruption of 


\section{CHARLES WATERTON}

Vesuvius ceased the moment St. Januarius's blood came in sight of the mountains." In Rome, again, he observes that the "scandalous deportment" of the Protestants in the churches is no doubt due to the legend that "the kindest and best of pontiffs is really the man of $\sin$, who gets drunk on the blood of nations." "Indeed, when I reflect on the horrible wickedness of England's. Coronation Oath ...."

"The devil, the Pope and the Pretender have been drummed into their ears (the Protestants) from childhood. Only the Pope is left, for the Pretender is dead, and the devil, if we may judge by the frightful increase of magistrates and prisons in England, has no spare time to be in Rome."

Coming home he was shipwrecked, because the captain, "this dastardly sansculotte," was "snoring in breechless state."

Thus we travel this literary land of milk and honey, through page after page of charmed and elfish narrative, more witty than sage, more shrewd than witty, and again more comical than shrewd, as Euphues might put it. The autobiography ends with an appropriate moral reflection: "Although life's index points at sixty-two, I am a stranger to all sexagenarian disabilities, and can mount to the top of a tree with my wonted steadiness and pleasure." Our learned and versatile squire, naturalist, poet, explorer, teetotaller, devout, taxidermist, recommender of Macintosh's life preserver, phlebotomist (he "tapped his own claret" eighty times), athlete, humanitarian, sculler, handler of rattlesnakes, and man of letters, leaves us, as is only fitting, in a poetic nimbus. "My time has been a mere sunbeam on a winter's day, a passing cloud in a tempestuous sky, sure monitors to put us in mind "that we are here now and gone in a moment '."

$\mathrm{Ah}$ ! rest assured, honest, playful and learned squire, that the account of your adventures has not "disedified. the teacher, nor caused a frown upon his face!" His only regret is that he cannot quote that wondrous, that super-Shandyesque story of yours, so decorous in its indecorum, about the ass and the two carriage horses. 
So, go little book, farewell and " remember my little fellow" not to be puffed up. For thou art but " a puny, and an ailing brat" and so need all the education $I$ have given thee "in passing through the dreary vale of criticism." "Thy path, my boy, is rough and thorny; be careful of thy steps."

Though the education of this superb old gentleman, this "fantastick great old man," as Lamb said of Burton, was "more in bogs than in books," he makes a naturalist of real knowledge and penetration, and ever buoyant and eager to pour his richness of illustration and analogy upon error and superstition. He made war upon nothing except the miserable Swainson and the Hanoverian rat, and was as humane a man and tender a lover of the works of creation as he was surprising a character. He knew his birds as well as he loved them, and handled poisonous reptiles " as if he had been leisurely selecting the sweetest bon-bon instead of the most vigorous rattlesnake." Time and again he has been proved wise in his generation by a later one. He was, I believe I am right in saying, the first naturalist to point out that humming-birds feed not only on the nectar of flowers but the insects they find in them, and that woodpeckers only attack a tree already bored by grubs. He was indeed one of the first naturalists to have any idea at all of the "web of life," of the poise and balance of nature and of the intrinsic value of every species in preserving them. In his way he was a prophet with the method in the prophet's madness. Before him, the natural history which discovers the meaning of life by patient watching and sympathy instead of exploiting it by the short cut through death to a barren knowledge hardly existed. Whenever he fell in with snakes in the jungle, whether poisonous or harmless,

"I would contemplate them for a few minutes, ere I proceeded, and would say 'gentlemen of rainbow colour, be not alarmed at my intrusion, I am not come hither to attempt your lives nor to offer wanton molestation. This boundless territory affords an ample range to both yourselves and me. Our interests can never clash as though we were in commerce. So pray enjoy yourselves, and let me do the same." 
There was once a scientific squabble as to the defective scent of the vulture, and when a vulture's eyes had been put out and he had refused food immediately afterwards, Waterton bursts forth with, "I myself have been unable to eat when in the gripes," and since the vultures have received such "a tremendous blow on the nose,"

"I am now quite prepared to receive accounts from Charleston of vultures attacking every shoulder-of-mutton sign in the streets, or attempting to gobble down the painted sausages over the shop doors, or tugging with might and main at the dim and faded eyes in some decaying portrait of the immortal Doctor Franklin."

What good sense there is here and expressed with how pungent a wit! He hated docking, and looked upon all "the animal creation" as beautiful, having a special fondness for the toad. Even when we see a dead cayman, "we may remark, with the monster hero, treading over his own prostrate mother, we did not think that they had been so handsome." His opinion about the "Hanoverian rat," "that it actually came over in the same ship which conveyed the new dynasty to these shores," is not perhaps strictly accurate, but who would not sacrifice all the exact classifications in the world for so seductive a comment? It was not considered true in his time that "the sooty-black crow is as chaste and constant as the snow-white dove"; but I for one, had I read Waterton in his lifetime, would never have believed otherwise. I shall know exactly what to do now "in case of collision with the larger canine tribes," I shall feel a particular veneration for the cormorant after reading: "Stay here, poor wandering mariner, so long as it pleaseth thee to do so. I do not care if thou takest all the eels in the lake. Thou art welcome to them."

Had Waterton given us nothing but whimsies, his were not only an odd but an obvious personality. But Waterton combines the incompatibles of truth and eccentricity, much in the same way that Lamb did. With Lamb the process was a conscious literary artifice, as it was with Lear's Fool. But Waterton reveals truth in and through a series of antics of which he was 


\section{BIRDS OF THE COUNTRYSIDE}

as unconscious as a pompous man is of the irony his demonstrations of truth excite. In his work, truth, that Quaker maid, enjoys herself in motley as to the manner born. His was a pane in the dome of manycoloured glass, not clouded like the others, but admitting the white radiance through an undimmed surface- of a very peculiar shape. His other dualism does not seem to us so remarkable as it was then. There are examples to-day of writers who recognize that art and science reach the same conclusions through different paths, Havelock Ellis, Arthur Thomson, W. H. Hudson, Patrick Geddes and a very few others, and doubtless there will be many more in the future, when art and science are seen to be indispensable and complementary to one another and our absurd departmentalizing of truth has been broken down. For science fulfils the law and the prophets, and the Honorary Presidents of the British Association should be Blake, Shelley, Wordsworth and Francis Thompson.

Modern science has made nature infinitely more interesting to man than ever before in the history of the world; it has heightened and broadened our knowledge of natural phenomena, not to the loss but the gain of our sense of wonder at the eternal fitness of things. The faculties of observation and imagination have come to supplement and strengthen each other in such a way that spiritual reality shall not degenerate into makebelieve and material reality into the staleness of wont. The most wonderful of fairy tales have turned out to be the facts and history of evolution, while the more profound among men of science have come more and more to use the terminology of art in expressing them. For the self-expression of nature is now seen to be in unity, individuality, creativeness and process the most masterly work of art revealed to human senses. Of this revelation Waterton is one of the pioneers. 

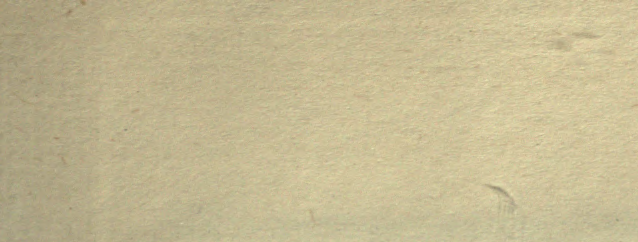
THIS BOOK IS DUE ON THE LAST DATE STAMIPED BELOW

AN INITIAL FINE OF 25 CENTS WILL BE ASSESSED FOR FAILURE TO RETURN THIS BOOK ON THE DATE DUE. THE PENALTY WILL INCREASE TO 50 CENTS ON THE FOURTH DAY AND TO \$1.0O ON THE SEVENTH DAY OVERDUE.

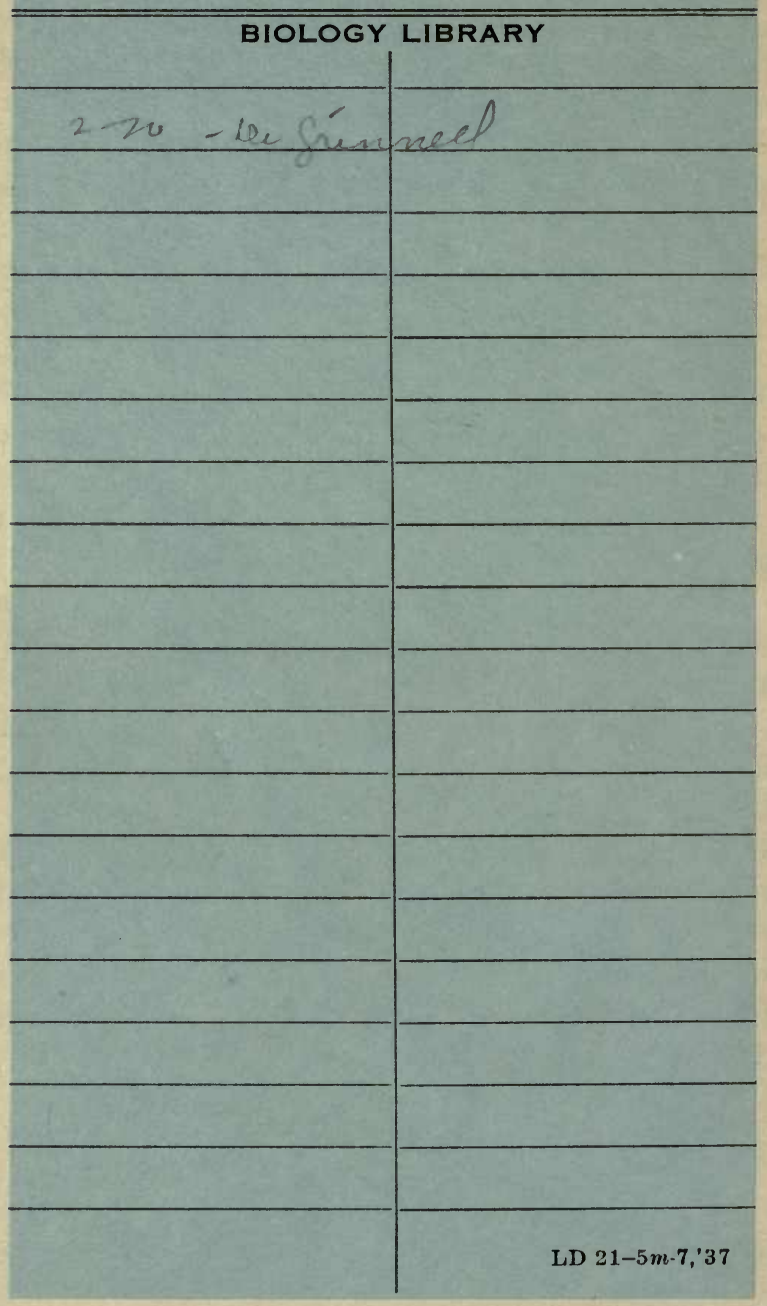




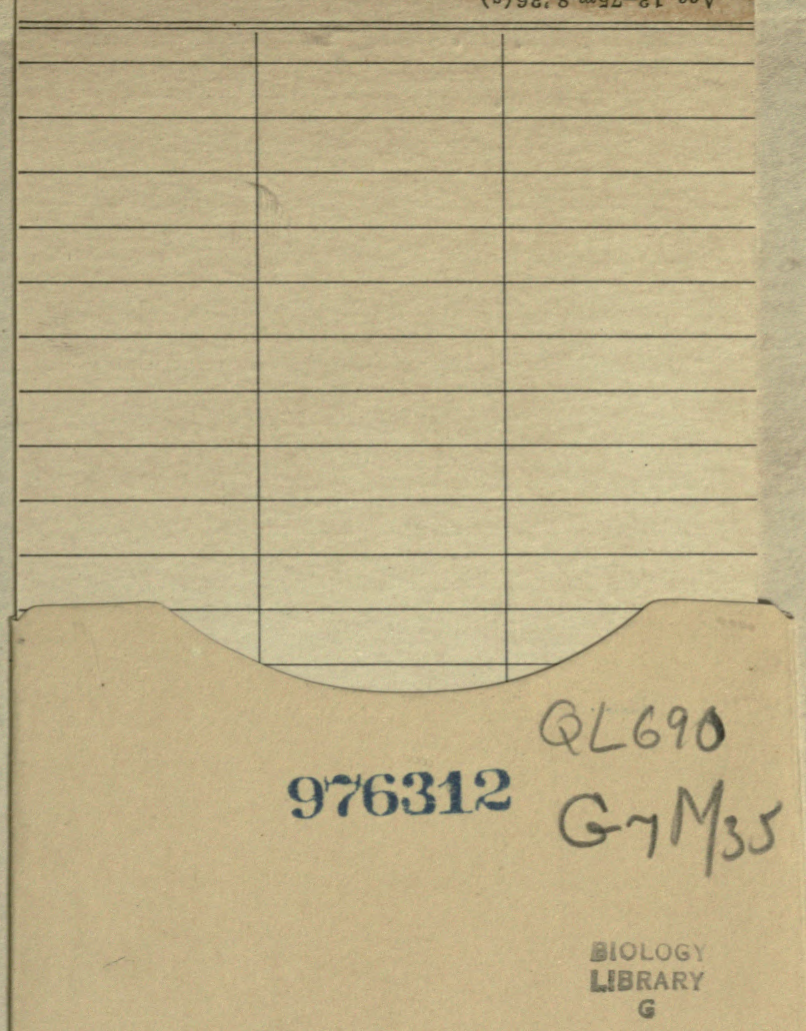

THE UNIVERSITY OF CALIFORNIA LIBRARY 
